\title{
ESTUDO DO DESEMPENHO ANIMAL E PRODUÇÃO DO CAPIM TANZÂNIA (Panicum maximum, Jacq.) EM UM SISTEMA ROTACIONADO DE PASTEJO SOB IRRIGAÇÃO EM TRÊS NÍVEIS DE RESÍDUO PÓS PASTEJO
}

\author{
Marco Antonio Penati
}

Tese apresentada à Escola Superior de Agricultura

"Luiz de Queiroz", Universidade de São Paulo, para obtenção do título de Doutor em Agronomia, Área de Concentração: Ciência Animal e Pastagens..

P I R A C I C A B A

Estado de São Paulo - Brasil

Janeiro - 2002 


\section{ESTUDO DO DESEMPENHO ANIMAL E PRODUÇÃO DO CAPIM TANZÂNIA (Panicum maximum Jacq.) EM UM SISTEMA ROTACIONADO DE PASTEJO SOB IRRIGAÇÃO EM TRÊS NÍVEIS DE RESÍDUO PÓS PASTEJO}

\section{Marco Antonio Penati}

Engenheiro Agrônomo

\footnotetext{
Tese apresentada à Escola Superior de Agricultura "Luiz de Queiroz", Universidade de São Paulo, para obtenção do título de Doutor em Agronomia, Área de Concentração: Ciência Animal e Pastagens.
}

P I R A C I C A B A

Estado de São Paulo - Brasil

Janeiro - 2002 
Dados Internacionais de Catalogação na Publicação (CIP)
DIVISÃO DE BIBLIOTECA E DOCUMENTAÇÃO - ESALQ/USP

Penati, Marco Antonio

Estudo do desempenho animal e produção do capim Tanzânia (Panicum maximum, Jacq.) em um sistema rotacionado de pastejo sob irrigação em três níveis de resíduo pós pastejo / Marco Antonio Penati. - - Piracicaba, 2002.

117 p. : il.

Tese (doutorado) - Escola Superior de Agricultura Luiz de Queiroz, 2002.

Bibliografia.

1. Bovino 2. Capim colonião 3. Desempenho animal 4. Forragem 5. Pastejo rotativo 6. Produtividade animal I. Título

CDD 636.2085

"Permitida a cópia total ou parcial deste documento, desde que citada a fonte - $\mathrm{O}$ autor" 


\begin{abstract}
À minha esposa Luciane e meus filhos Marcelo e Mariana, pela compreensão e incentivo.
\end{abstract}

\title{
DEDICO
}

Aos meus pais, Moacir (in memoria) e Dolores, a vovó Hieda, Tia Cláudia e a minha família,

pela dedicação, apoio e carinho. 


\section{AGRADECIMENTOS}

Ao Prof. MOACYR CORSI, pela orientação, apoio, amizade, incentivo e formação profissional;

Aos meus amigos de pós graduação, DANIEL DA SILVA PAGOTTO, GERALDO BUENO MARTHA JR., LUIS GUSTAVO BARIONI, MARCO ANTONIO ALVARES BALSALOBRE, PATRÍCIA MENEZES SANTOS, pelo companherismo, colaboração e espírito de união no trabalho;

Ao magnífico grupo de ESTAGIÁRIOS do projeto CAPIM pela dedicação, força de trabalho, respeito, alegria durante os serviços;

Aos Professores CÉSAR GONÇALVES DE LIMA, CARLOS TADEU DA SILVA DIAS e MARIA IZALINA F. ALVES e da pós graduanda JULIANA G. GIANNOTTI pelo auxílio nas análises estatísticas.

À FAPESP e a CAPES pelos recursos destinados a elaboração desse projeto e pela concessão da bolsa de estudo, respectivamente.

Ao Prof. VIDAL PEDROSO DE FARIA, pela seu exemplo de homem, conduta moral e de vida.

Aos meu amigo Giovano Justi Cezare pela ajuda e para o CPZ pela formação profissional e de conduta humana. 


\section{SUMÁRIO}

Página

LISTA DE FIGURAS........................................................................ viii

LISTA DE TABELAS........................................................................... xiii

LISTA DE ABREVIATURAS E SÍMBOLOS................................................ xix

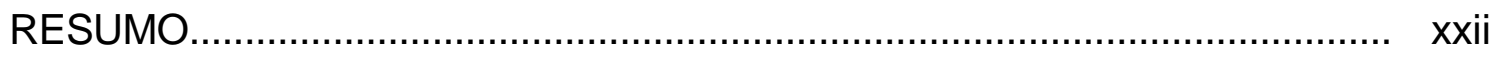

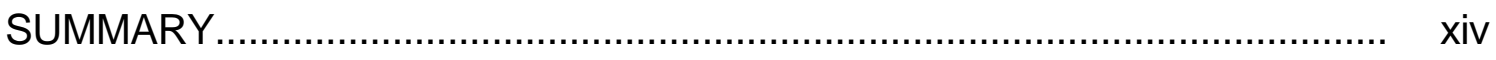

1 INTRODUÇÃO

2 REVISÃO DE LITERATURA.....................................................................

2.1 Amostragem para estimar a massa de foragem....................................... 3

2.2 Efeito do manejo sobre a produção animal, características morfológicas

e produção das pastagens.....................................................................

2.2.1 Relação entre características morfológicas da planta e do manejo sobre o desenvolvimento das pastagens....................................................... 4

2.2.2 Efeito do manejo da pastagem sobre o desempenho e produtividade

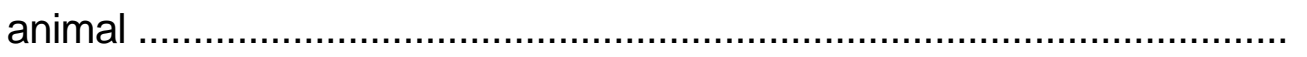

2.2.3 Efeito do manejo da pastagem sobre a eficiência de pastejo

- perdas. 
3 MATERIAL E MÉTODOS...

3.1 Estabelecimento da área experimental.

3.2 Material e métodos utilizados para a condução do experimento para determinar a metodologia a ser empregado para estimar a massa de forragem.

3.2.1 Pré experimento 1 32

3.2.2 Pré experimento 2 e 3

3.3 Determinação da massa de forragem, perdas e da relação entre as frações folha verde, haste verde e material morto.

3.4 Manejo das pastagens, desempenho animal, lotação e produtividade

3.5 Distribuição vertical da densidade de forragem no perfil da touceira.

3.6 Taxa de ocupação, angulo da touceira e disposição das folhas no perfil do dossel

3.7 Análise estatística.

3.8 Estimativas de alguns parâmetros baseados nas determinações de características de produção da planta forrageira.

4 RESULTADOS E DISCUSSÃO.

4.1 Escolha do número e relação dimensão:formato da unidade amostral para estimar a massa de forragem......

4.2 Efeito da altura da pastagem sobre a profundidade de pastejo ................ 60

4.3 Massa de forragem e altura do pasto após os pastejo (resíduo).

4.4 Relação entre as características morfológicas da planta e do manejo sobre o desenvolvimento das pastagens. 
4.5 Produção de forragem e desempenho animal....................................... 85

4.6 Produtividade animal......................................................................... 102

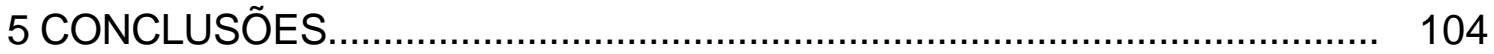

REFERÊNCIAS BIBLIOGRÁFICAS........................................................ 106 


\section{LISTA DE FIGURAS}

Página

1 Relações entre as características morfogenéticas e estruturais da pastagem.

2 Relação entre o comprimento final estimado da folha pela eq. (1) e o os valores observados para diferentes espécies nos Pampas Argentinos.

3 Relações entre a altura da superfície da pastagem e ingestão de forragem (a) ou desempenho animal (b) de animais em pastejo sob lotação contínua.

4 Efeito da oferta de forragem em capim Tanzânia no ganho médio diário geral (GMDG), ganho por ha geral $(\mathrm{G} / \mathrm{haG})$, ganho médio diário no período verão-outono e inverno (GMDV e GMDI, respectivamente) e ganho por ha no verão-outono e inverno (G/haV e G/hal, respectivamente).

5 Influência da oferta de forragem presente na pastagem no ganho de peso vivo de ovelhas em diferentes disponibilidades de forragem 
6 Croqui da área experimental indicando as respectivas faixas dos tratamentos, blocos e dos piquetes $\mathrm{A}, \mathrm{B}$ e $\mathrm{C}$

7 Croqui das molduras indicando as divisões internas para proporcionar as relações dimensão-formato. Os valores nos eixos $X$ e $Y$ são

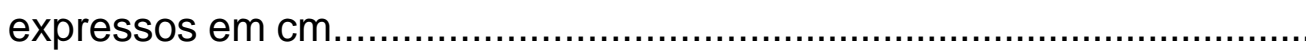

8 Croqui das linhas transectas para orientar nas amostragens de forragem para avaliação da produção de massa no pré, pós - pastejo e das perdas de forragem

9 Croqui indicando os locais de onde são medidas as alturas das plantas no interior das molduras de $1 \mathrm{~m} \times 1 \mathrm{~m}$ usadas para avaliar a massa se forragem

10 Fotografia das amostras preparadas para serem empacotadas e congeladas para depois serem utilizadas para àavaliação da distribuição vertical da massa de forragem no perfil da touceira ou do dossel.

11 Imagem do perfil de um touceira de capim Tanzânia cortada vertical no meio da sua área basal que lembra o formato de um cone invertido

12 Croqui comparando os formatos da touceira ou das plantas por ocasião do corte (A) e posicionando os perfilhos e suas folhas de forma ereta e esticados para cima (B). Esta sendo indicado como os estratos forma separados

13 Croqui indicando o formato ( $A$ e $B$ ) e o angulo ( $a$ e b) da touceira antes e após o primeiro dia de pastejo, respectivamente 
14 Imagem do perfil de um touceira de capim Tanzânia cortada vertical no meio da sua área basal e marcada com uma linha branca indicando inclinação por perfilhos mais externos da touceira. A sequência de pontos vermelhos representam o formato externo da touceira

15 Imagem do perfil de um touceira de capim Tanzânia (após o primeiro dia de pastejo) cortada verticalmente no meio da sua área basal que lembra o formato de um cone invertido

16 Coeficiente de variação em função do número de amostras em cada relação dimensão:formato.

17 Coeficientes de variação médios das 48 interações entre os fatores número de amostras e relação dimensão:formato no Experimento 3 (capim Tanzânia - pós pastejo). A sigla $4 \times 1 Q$ significa 4 amostras, ou unidades amostrais, de $1 \mathrm{~m}^{2}$ no formato quadrado. As setas no mesmo sentido superior e inferior representam as interações que são iguais as combinações $5 \times 1 \mathrm{Q}$ e $4 \times 1 \mathrm{Q}$, respectivamente

18 Relação entre a altura da planta antes do pastejo e a altura da planta após cada dia de pastejo nos piquetes do tratamento 1

19 Relação entre a altura das planta antes do pastejo e a altura da planta após cada dia de pastejo nos piquetes do tratamento 3 
20 Relação entre a altura da planta antes do pastejo e o porcentual da altura inicial da planta (antes do pastejo) em cada dia de pastejo nos piquetes do tratamento 1

21 Relação entre a altura da planta antes do pastejo e o porcentual da altura inicial da planta (antes do pastejo) em cada dias de pastejo nos piquetes do tratamento 3

22 Relação entre altura da pastagem antes do pastejo com a massa de forragem

23 Formato e distribuição das touceiras na pastagem em função da intensidade de pastejo. As letras a, b e c representam a distância entre touceiras, diâmetro da área basal da touceira e altura da planta. O desenho com letras maiúsculas representa a pastagens com menor intensidade de pastejo

24 Croqui de touceiras vizinhas com suas folhas em sobreposição. $H=$ altura $(\mathrm{cm}) ; \mathrm{a}=$ angulo de inclinação da touceira $\left({ }^{\circ}\right) ; \mathrm{D}=$ distância entre touceiras $(\mathrm{cm}) ; \mathrm{d}=$ diâmetro da área basal da touceira $(\mathrm{cm}) ; \mathrm{S}=$ diâmetro da área de sombreamento da touceira $(\mathrm{cm}) ; \mathrm{s}=$ sobreposição entre as folhas das touceiras vizinhas em função de $S$ (\%)

25 Redução da altura $(\mathrm{H})$ necessária para ocorrer o sombreamento em função do aumento na altura de pastejo (HP) 
26 Formato externo das touceiras representado pelas equações quadráticas. Não houve diferença entre as equações a $p<0.05$. O perímetro da touceira e o solo foram definidos como $0 \%$ enquanto que os pontos mais altos do solo e distantes da touceira foram definidos

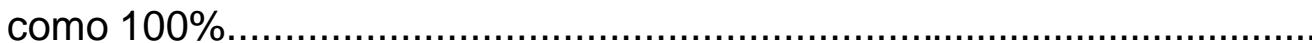




\section{LISTA DE TABELAS}

Página

1 Dados de temperatura e radiação solar medidos na estação meteorológica da ESALQ durante o período experimental.

2 Concentração de micronutrientes no fertilizante FTE-BR12................... 29

3 Resultados de análises químicas de solo amostrado a $0-20 \mathrm{~cm}$ de profundidade por tratamento (média dos quatro blocos)................... 30

4 Peso vivo em $\mathrm{kg}$ dos animais testers primários no primeiro dia (30/10/1999) do período experimental.

5 Distribuição dos ciclos de pastejo nas épocas e seus respectivos períodos de ocorrência.

6 Nível descritivo (p) para comparação entre os coeficientes de variação (CV\%) médios da relação dimensão-formato no pré experimento 1 (capim Elefante)

7 Nível descritivo ( $p$ ) para comparação entre os coeficientes de variação (CV\%) médios da relação dimensão-formato no pré experimento 2 (capim Tanzânia - pré pastejo) 
8 Nível descritivo (p) para comparação entre os coeficientes de variação (CV\%) médios do número de amostras através do teste t no pré experimento 1 (capim Elefante)

9 Nível descritivo (p) para comparação entre os coeficientes de variação (CV\%) médios do número de amostras através do teste t no pré experimento 2 (capim Tanzânia - pré pastejo)

10 Nível descritivo $(p)$ para comparação entre os coeficientes de variação (CV\%) médios da relação dimensão-formato no pré experimento 3 (capim Tanzânia - pós pastejo).

11 Nível descritivo (p) para comparação entre os coeficientes de variação $(\mathrm{CV} \%)$ médios do número de amostras através do teste t no pré experimento 3 (capim Tanzânia - pós pastejo)

12 Massa de forragem verde verde pós pastejo (resíduo) (MFVR) em função dos tratamentos e das épocas do ano

13 Altura média das pastagens no resíduo (AR) em função dos tratamentos e das épocas do ano.

14 Relação folha/haste média nas plantas antes dos pastejos (FHP) em função dos tratamentos e das épocas de ano.

15 Participação média de haste nas plantas antes dos pastejos (HP\%) em função dos tratamentos e das épocas do ano

16 Participação média de folhas nas plantas antes dos pastejos (FP\%) em função dos tratamentos e das épocas do ano. 
17 Produção média de haste antes dos pastejos (HPHA) em função

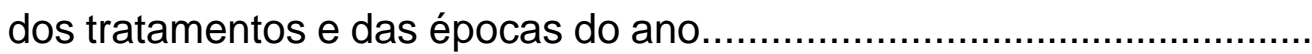

18 Produção média de folhas antes do pastejo (FPHA) em função dos tratamentos e das épocas do ano.

19 Produção média de material morto antes dos pastejos (MMPHA) em função dos tratamentos e das épocas do ano.

20 Participação média de material morto nas plantas antes dos pastejos (MMP\%) em função dos tratamentos e das épocas do ano

21 Densidade média de forragem antes dos pastejos (DP) em função dos tratamentos e das épocas do ano

22 Densidade média de forragem (DPE) antes dos pastejos em vários estratos do perfil do dossel em função dos tratamentos sem considerar o estrato correspondente ao resíduo (7)

23 Densidade de forragem antes do pastejo em vários estratos do perfil do dossel em função dos tratamentos e corrigido pelo formato da planta (DPEC) sem considerar o estrato correspondente ao resíduo (7).

24 Taxa de ocupação do solo pela área basal da touceira (TO) em função dos tratamentos e das épocas do ano.

25 Porcentagem de touceiras de 1 e 2 pontos em relação ao número total de touceiras em função dos tratamentos e das épocas do ano 
26 Altura média das pastagens antes dos pastejos (AP) em função dos tratamentos e das épocas do ano

27 Ritmo de crescimento da planta necessário para ocorrer a sobreposição de $10 \%$ das folhas das touceiras vizinhas em 20 dias após o corte ou pastejo seguindo o modelo 1

28 Ritmo de crescimento da planta necessário para ocorrer a sobreposição de $10 \%$ das folhas das touceiras vizinhas em 20 dias após o corte ou pastejo seguindo o modelo 2

29 Resultados das análises estatísticas de algumas variáveis relacionadas a produção animal e vegetal sobre o efeito dos tratamento durante 0 período de 30 de outubro de 1999 a 3 de janeiro de 2001 sem considerar o ciclo 9

30 Produção média de matéria seca antes dos pastejos (PMSP) em função

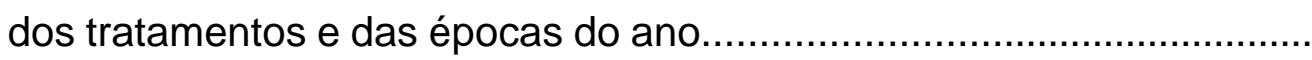

31 Produção média de matéria seca verde antes dos pastejos (PMVP) em função dos tratamentos e das épocas do ano.................................

32 Taxa média de acúmulo de material morto antes dos pastejos (MMAC) em função dos tratamentos e das épocas do ano...................................

33 Taxa média de acúmulo de matéria seca antes dos pastejos (ACMS) em função dos tratamentos e das épocas do ano

34 Taxa média de acúmulo de matéria seca verde antes dos pastejos (ACMV) em função dos tratamentos e das épocas do ano 
35 Taxa média de lotação animal (LA) em função dos tratamentos e das

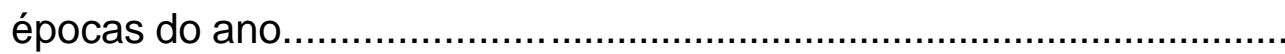

36 Perdas de forragem relativas a produção de forragem (PER\%) em função dos tratamentos e das épocas do ano.

37 Quantidade de forragem perdida (PERHA) em função dos tratamentos e das épocas do ano.

38 Participação de material morto na forragem perdida (MMPER\%) em função dos tratamentos e das épocas do ano.

39 Quantidade de haste perdida (HPEHA) em função dos tratamentos e das épocas do ano

40 Quantidade de folhas perdidas (FPEHA) em função dos tratamentos e das épocas do ano.

41 Média dos ganho de peso vivo (GPV) em função dos tratamentos e das épocas do ano.

42 Relação folha/haste média nas pastagens após os pastejos (FHR) em função dos tratamentos e das épocas do ano

43 Média das relações folha/haste média nas pastagens antes e após os pastejos (FHM) em função dos tratamentos e das épocas do ano.

44 Oferta de matéria seca verde antes dos pastejos (OFEPP) em função dos tratamentos e das épocas do ano 
45 Oferta de matéria seca verde após os pastejos (OFEPR) em função

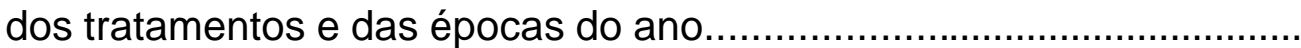

46 Ofertas médias entre as ofertas de matéria seca verde antes e após os pastejos (OFEPM) em função dos tratamentos e das épocas do ano

47 Ofertas médias entre as ofertas de folhas antes e após os pastejos (OFEFM) em função dos tratamentos e das épocas do ano

48 Ofertas médias entre as ofertas de haste antes e após os pastejos (OFEHM) em função dos tratamentos e das épocas do ano.

49 Perdas de matéria seca por unidade animal (PERUA) em função dos tratamentos e das épocas do ano.

50 Produtividade animal por ha (PRODU) em função dos tratamentos e das épocas do ano 


\section{LISTA DE ABREVIATURAS, SIGLAS E SÍMBOLO}

ACMS Taxa média de acúmulo de matéria seca antes dos pastejos

ACMV Taxa média de acúmulo de matéria seca verde antes dos pastejos

AP $\quad$ Altura média das plantas antes dos pastejos

AR Altura média das plantas no resíduo

CV\% Coeficiente de variação

DP Densidade média de forragem antes dos pastejos

DPE Densidade média de forragem antes dos pastejos nos estratos do perfil do dossel

DPEC Densidade de forragem antes do pastejo nos estratos do perfil do dossel corrigido pelo formato da planta

DT Diâmetro da touceira

EP Eficiência de pastejo

FHP Relação folha/haste nas plantas antes do pastejo

FHR Relação folha/haste média nas pastagens após os pastejos

FHM Média das relações folha/haste média nas pastagens antes e após os pastejos

FP\% Participação das folhas na planta

FPEHA Quantidade de folhas perdidas por ha

FPHA Produção média de folhas antes do pastejo

GPV Ganho de peso vivo

HP\% Participação da haste na planta antes do pastejo 
HPERHA Quantidade de haste perdida por ha

HPHA Produção média de haste antes dos pastejos

IAF Índice de área foliar

LA Lotação animal

LAM Lotação animal média

MFR Massa de forragem do resíduo

MFVR Massa de forragem pós pastejo ou do resíduo

MFVRT Produção total de matéria seca verde

MMAC Taxa média de acúmulo de material morto antes dos pastejos

MMP\% Participação média de material morto nas plantas antes dos pastejos

MMPER\% Participação de material morto na forragem perdida

MMPHA Produção média de material morto antes dos pastejos

MS Matéria seca

MSV Matéria seca verde

OFEFM Oferta média entre as ofertas de folhas antes e após os pastejos

OFEHM Oferta médias entre as ofertas de haste antes e após os pastejos

OFEPM Oferta média entre as ofertas de matéria seca verde antes e após os pastejos

OFEPP Oferta de matéria seca verde antes dos pastejos

OFER Oferta de matéria seca verde após os pastejos

PER\% Perdas de forragem relativas a produção de forragem

PERHA Quantidade de forragem perdida

PERUA Perdas de matéria seca por unidade animal

PMSP Produção média de matéria seca antes dos pastejos

PMVP Produção média de matéria seca verde antes dos pastejos

PRODU Produtividade animal média por ciclo ajustando o número de cabeças em função do PV médio dos testers

Produtividade total ajustando o número de cabeças em função 


$\begin{array}{ll}\text { PROTO } & \text { do PV médio dos testers } \\ \text { PTMSP } & \text { Produção total de matéria seca antes do pastejo } \\ \text { PTMVP } & \text { Produção total de matéria seca verde antes do pastejo } \\ \text { PTAMS } & \text { Produção total acumulada de matéria seca } \\ \text { PTAMV } & \text { Produção total acumulada de matéria seca verde } \\ \text { PTH } & \text { Produção total de haste } \\ \text { PTAH } & \text { Produção total acumulada de haste } \\ \text { PTF } & \text { Produção total de folhas } \\ \text { PTAF } & \text { Produção total acumulada de folhas } \\ \text { PTMM } & \text { Produção total de material morto (kg MS/ha) } \\ \text { PTAMM } & \text { Produção total acumulada de material morto } \\ \text { PV } & \text { Peso vivo } \\ \text { RC } & \text { Ritmo de crescimento da planta } \\ \text { TAF } & \text { Taxa de elongação das folhas } \\ \text { TAPF } & \text { Taxa de aparecimento de folhas } \\ \text { TDA } & \text { Tempo de duração de alongamento das folhas } \\ \text { TF } & \text { Tamanho da folha } \\ \text { TO } & \text { Taxa de ocupação da área pelas plantas ou taxa de ocupação } \\ & \text { do solo pela área basal da touceira } \\ \text { TT } & \text { Tamanho das touceiras }\end{array}$




\section{ESTUDO DO DESEMPENHO ANIMAL E PRODUÇÃO DO CAPIM TANZÂNIA (Panicum maximum, Jacq.) EM UM SISTEMA ROTACIONADO DE PASTEJO SOB IRRIGAÇÃO EM TRÊS NÍVEIS DE RESÍDUO PÓS PASTEJO}

Autor: Marco Antonio Penati Orientador: Prof. Dr. Moacyr Corsi

\section{RESUMO}

O objetivo dessa pesquisa foi o de avaliar o efeito de massa de forragem no resíduo sobre as características morfológicas, produção das pastagens, desempenho e produtividade animal. O experimento foi desenvolvido no período de 30 de outubro de 1999 até 03 de janeiro de 2001 em um sistema rotacionado de pastagens irrigadas de Panicum maximum Jacq. cv. Tanzânia estabelecidas na Escola Superior de Agricultura "Luiz de Queiroz" em Piracicaba/SP. O delineamento experimental foi o de blocos (4) completos ao acaso com três disponibilidades de forragem no resíduo (1000, 2500 e 4000 $\mathrm{kg} / \mathrm{ha}$ de matéria seca verde (MSV)). A semeadura foi realizada em 17 de março de 1999 e a adubação de correção do solo tinha o objetivo de atingir os seguintes valores: $80 \%$ de saturação por bases; $30 \mathrm{mg} / \mathrm{cm}^{3}$ de fósforo e $5 \%$ de potássio na CTC. Os piquetes foram adubados com $334 \mathrm{~kg} / \mathrm{ha} /$ pastejo de 2404-24. Os animais utilizados foram machos castrados da raça nelore com cerca de 10 meses de idade. Foram conduzidos quatro pré experimentos sendo três 
deles para deteminar a melhor relação dimensão:formato da unidade amostral e a quantidade de amostras para avaliar a massa de forragem. O quarto pré experimento teve como objetivo avaliar a relação entre profundidade de pastejo e altura das planta antes do pastejo. A avaliação da massa de forragem em piquetes estabelecidos com plantas que formam touceiras deve ser realizada através de quatro amostras de $1 \mathrm{~m}^{2}(1 \mathrm{~m} \times 1 \mathrm{~m})$. A profundidade de pastejo foi relacionada linearmente com a altura das plantas independente da intensidade de pastejo e do dia de ocupação do pasto. A intensidade de pastejo não teve efeito sobre o angulo de inclinação dos perfilhos mais externos da touceira, sobre o formato das touceiras e sobre a distribuição da densidade de forragem no perfil da pastagem indicando que o capim Tanzânia tem pouca plasticidade em relação a essas características. Entretanto a proporção de haste, de folhas, de material morto, da altura, da relação folha/haste foram características morfológicas afetadas pelos tratamentos e épocas do ano. A taxa de cobertura do solo diminuiu durante período experimental independente do tratamento enquanto que o tamanho das touceiras esteve associado a mecanismos rápidos de adaptação da planta a mudanças no meio ambiente causadas pelas diferentes disponibilidades de forragem. $O$ desempenho animal esteve mais relacionado com a oferta e disponibilidade de forragem do que com a relação folha/haste e a densidade de forragem. Apesar da produtividade animal não ser alterada pelos tratamentos, o manejo mais adequado seria o de manter a disponibilidade de forragem no resíduo superior a $2915 \mathrm{~kg} \mathrm{MSV} / \mathrm{ha}$ assim como as ofertas de forragem maiores do que $14,9 \mathrm{~kg} \mathrm{MSV} / 100 \mathrm{~kg} P V$ ou $6,1 \mathrm{~kg}$ de folhas $/ 100 \mathrm{~kg}$ PV afim de melhorar o desempenho dos animais e reduzir a idade de abate em 150 dias quando comparado com o tratamento que teve como massa de forragem no resíduo $1266 \mathrm{~kg} \mathrm{MSV/ha.}$ 


\section{STUDY OF THE ANIMAL PERFORMANCE AND HERBAGE PRODUCTION OF IRRIGATED TANZANIA GRASS (Panicum maximum, Jacq.) IN A ROTATIONAL GRAZING SYSTEM UNDER THREE POST-GRAZING RESIDUES LEVELS}

Author: Marco Antonio Penati Adviser: Prof. Dr. Moacyr Corsi

\section{Summary}

This research was to evaluate effect of the post-grazing pasture mass on morphological characteristics, herbage production and animal performance and productivity from irrigated and rotationally grazed system with Panicum maximum Jacq. cv. Tanzânia. The experimental period was October 30/1999 to January 03/2001 and established at Escola Superior de Agricultura "Luiz de Queiroz", Piracicaba/SP. A complete randomized block design with three postgrazing residues $(1.000,2.500$ e $4.000 \mathrm{~kg} / \mathrm{ha}$ of green dry matter - GDM) and four replicates was used. The grass seeding was performed on March 17/1999 and soil was limed and fertilized to $80 \%$ base saturation, phosphorus (resin) level of $30 \mathrm{mg} / \mathrm{cm}^{3}$ and $5 \%$ potassium in the cation exchange capacity. In each grazing cycle paddocks were fertilized with 24-04-24 (334 kg/ha). Nellore steers with approximately 10 months of age were used. Four pre-experiments were conducted, the first three to determine the best dimesion:format ratio of the 
sampling unit and the most appropriate number of samplings in evaluating herbage mass. The fourth pre-experiment aimed to evaluate the relationship between grazing depth (progressive sward defoliation during the grazing period) and plant height before grazing. Herbage mass evaluation in tussock-forming pastures should be performed taking four $1 \mathrm{~m}^{2}$ samples $(1 \mathrm{~m} \times 1 \mathrm{~m})$. Grazing depth was linearly correlated to plant height, irrespective of grazing intensity and days on the grazing period. Grazing intensity had no effect on the slope of the angle between soil and tillers on the border of the tussock, neither on tussock shape nor on forage bulk density across the sward profile, indicating Tanzania grass has limited plasticity for these characteristics. However, stem, leaf and dead material proportion in herbage samples, as well as leaf/stem ratio and plant height were affected by treatments (post-grazing residues) and season of the year. The ground area covered by grass tussocks decreased during the experimental period, irrespective of the treatment. The tussock size was associated with fast adaptation mechanisms of the plants in response to changes in environment resulting from different post-grazing herbage masses. Animal performance was better related to herbage allowance and post-grazing residues than with leaf/stem ratio or forage bulk density. Treatments did not altered animal productivity. In spite of this, it would be more adequate to allow post-grazing pasture mass to be higher than $2.915 \mathrm{~kg} \mathrm{GDM} / \mathrm{ha}$ and herbage allowance to be higher than $14,9 \mathrm{~kg}$ GDM/100 kg live weight (LW) or $6,1 \mathrm{~kg}$ of leaves $/ 100 \mathrm{~kg} \mathrm{LW}$. This grazing management would improve animal performance and anticipate slaughter age in 150 days when compared to the treatment with post-grazing pasture mass of $1.266 \mathrm{~kg}$ GDM/ha. 


\section{INTRODUÇÃO}

A importância das pastagens na produção de bovinos no Brasil é inquestionável. Estima-se que $75 \%$ da superfície utilizada pela agricultura seja ocupada por pastagens, o que corresponde a aproximadamente $20 \%$ da área total do país (Faria et al., 1996). Além do aspecto físico, as plantas forrageiras são importantes pelo papel que desempenham na alimentação dos bovinos, uma vez que $88 \%$ da carne produzida no país advém de rebanhos mantidos exclusivamente a pasto (Arruda, 1997).

Neste cenário, constata-se, com relativa frequência, o insucesso da pecuária nacional, independentemente da espécie ou cultivar de planta forrageira escolhida e/ou do método de pastejo adotado. Tal situação é consequência da falta de uso de tecnologia apropriada, geralmente associada com o manejo inadequado do solo e/ou da planta (Penati et al., 1999).

A produtividade animal é função da produção de massa de forragem, eficiência de utilização dessa massa e do desempenho animal e por sua vez, essas variáveis estão relacionadas æ̀ características químicas e estruturais da pastagem. A produção animal no pasto depende da disponibilidade de forragem e do valor nutritivo da massa ofertada. A qualidade da pastagem "in situ" depende de seus constituintes que variam no perfil desta em função das espécies presentes, da parte da planta, sua posição no dossel e da idade (Nabinger, 1997).

A produção do pasto e a sua estrutura morfológica são influenciadas por práticas de manejo como altura do pasto, área foliar e massa de forragem 
remanescente do pastejo. O objetivo dessa pesquisa é o de avaliar o efeito da massa de resíduo pós pastejo sobre as características morfológicas, produção das pastagens, desempenho e produtividade animal. 


\section{REVISÃO DE LITERATURA}

\subsection{Amostragem para estimar a massa de forragem}

O método utilizado para estimar a massa de forragem em pastagens deve ser preciso e exato o suficiente para definir diferenças entre tratamentos que alteram a produção das pastagens. O método destrutivo estima a produtividade da pastagem através da colheita da massa de forragem em parcelas (ou sub-parcelas, ou amostras) de área conhecida locadas no campo aleatoriamente, sistematicamente ou estratificadamente (Mclntyre, 1987). O formato, dimensão e quantidade de parcelas utilizadas interferem no nível de precisão e exatidão da amostragem (Frame, 1981). A definição desses valores é um dos problemas básicos encontrado pelos pesquisadores visando reduzir o erro experimental decorrente da heterogeneidade das parcelas (Guzman et al., 1992).

O formato retangular torna a operação de colheita mais eficiente e, além disso, há hipótese de que, em pastagens caracterizadas pela presença de touceiras, o formato retangular proporciona um menor coeficiente de variação na amostragem pois nesse formato fica mais difícil da moldura ficar posicionada entre as touceiras (sub-estimando a produção) ou englobando-as (super estimando a produção).

O tamanho da moldura esta relacionado positivamente com o tamanho da planta (Mclntyre, 1987). O autor sugere que em pastagens formadas com plantas que entouceram e nos campos com vegetação de deserto a prática de 
reduzir o tamanho da moldura e aumentar o número de amostras como forma de reduzir a quantidade de área amostrada sem afetar a variabilidade amostral não é recomendada.

O tamanho das molduras variam de 0,25 a $3,0 \mathrm{~m}^{2}$ nos formatos quadrado e retangular e o número de amostras variam de 5 a 20 por piquete, bloco, ou tratamento (Frame, 1981).

\subsection{Efeito do manejo sobre a produção animal, características morfológicas e produção das pastagens}

Algumas características morfológicas da planta forrageira (relação haste/folha, altura, densidade, distribuição vertical e horizontal das plantas ou da biomassa no pasto, etc.) e práticas de manejo (massa de resíduo pós pastejo, oferta de forragem, altura pré e pós pastejo, pressão de pastejo, área foliar remanescente, etc.) afetam o crescimento da planta e o desempenho animal em pastejo.

O estudo do comportamento das características morfológicas da planta e a forma como elas se relacionam em função de mudanças nas condições ambientais e/ou de manejo são importantes para definir práticas de manejo que sejam capazes de atender o objetivo do produtor a curto, médio ou longo prazo.

\subsubsection{Relação entre características morfológicas da planta e do manejo sobre o desenvolvimento das pastagens}

A taxa de crescimento da planta após o pastejo esta relacionada com:

a) a interceptação e eficiência de utilização da radiação solar que podem estar relacionadas com as características morfológicas das plantas (quantidade, idade e disposição das folhas e da haste no dossel) e das reações bioquímicas 
no processo de fotossíntese envolvendo a característica genética e os processos metabólicos de fixação de carbono;

b) quantidade e qualidade da massa de forragem pós pastejo alterando a capacidade da planta forrageira renovar o índice de área foliar (IAF) através de meristemas apicais remanescentes ou da capacidade de regeneração através da diferenciação de gemas;

c) concentração de reservas metabólicas (nitrogênio e carboidratos) no tecido remanescente pós pastejo;

d) quantidade e grau de a tividade do sistema radicular;

e) condições ambientais (temperatura, precipitação, fotoperíodo, radiação);

f) atributos físicos, químicos e biológicos do solo.

Peternelli et al. (2000) observaram que pastagens de capim Tanzânia (Panicum maximum Jacq.) mantidas sob um sistema de pastejo continuo com carga variável, apresentaram respostas lineares das variáveis massa seca de forragem, massa seca verde de haste e massa seca de material morto com a altura de pastejo cuja amplitude foi de 24,6 a $71,4 \mathrm{~cm}$. Entretanto, a quantidade de massa seca verde de folhas apresentou relação quadrática negativa, ou seja, a quantidade de folhas verdes aumentou até cerca de $61 \mathrm{~cm}$ de altura e depois decresceu. Os autores concluíram que a pastagem degradaria se a altura do pastejo fosse inferior a $24,6 \mathrm{~cm}$ e que nos pastejos mais altos o acúmulo excessivo de haste reduziria a qualidade da forragem e dificultaria a sua apreensão pelos animais.

Observações semelhantes foram obtidas por Silva et al. (1994) estudando a oferta da massa seca verde de capim Elefante anão (Pennisetum purpureum Schum. cv. Anão Mott.). Esses autores notaram uma queda da produção de matéria seca verde (MSV), ao longo do período experimental, de 5600 para 3445 e de 7750 para $3642 \mathrm{~kg} / \mathrm{ha}$ quando a oferta de forragem foi de 9 para 6 e de 6 para $3 \mathrm{~kg}$ de matéria seca (MS)/100 kg de peso vivo (PV), por 
ocasião da entrada e saída dos animais dos piquetes, respectivamente. Entretanto, quando a oferta de forragem foi de 12 para $9 \mathrm{~kg}$ de MS/100 kg de PV a disponibilidade de forragem permaneceu estável e próxima de $6500 \mathrm{~kg} / \mathrm{ha}$ de MSV.

Esses resultados suportam o trabalho de Costa et al. (2000) onde o aumento na pressão de pastejo de 10 a 12 para 6 a $8 \%$ do PV em um sistema rotacionado de pastagens estabelecidas com capim Tanzânia reduziu a disponibilidade de forragem de 4,92 para 2,96 t/ha de matéria seca verde, respectivamente. Entretanto, a massa de forragem no resíduo foram iguais e esse fato pode explicar ausência do efeito dos tratamentos sobre 0 desempenho animal.

Devemos ser criteriosos ao analisarmos trabalhos que avaliam a resposta da planta ou do animal em função da pressão de pastejo pois ofertas maiores de forragem por animal, geralmente induz a pastejos mais altos e/ou com maiores massa de forragem no resíduo (Almeida et al., 2000a; Almeida et al., 2000b; Grasselli et al., 2000 e Bortolo et al., 2001a) e/ou IAF (Fagundes et al., 1999 e Grasselli et al, 2000). Além disso, a amplitude dos parâmetros, observados ou impostos na pesquisa, altura de pastejo, massa de forragem residual, quantidade de folhas e IAF, também devem ser considerados na avaliação dos efeito do manejo sobre o desenvolvimento das pastagens e/ou do animal.

Desse modo, o trabalho de Grasselli et al. (2000) com pastagens de Braquiária decumbens indicou que o aumento na altura de pastejo, que variou de 7 até $22 \mathrm{~cm}$, foi associado positivamente àmassa de forragem pós pastejo e ao IAF do dossel. Entretanto a intercepção de luz apresentou um resposta quadrática e negativa $\left(R^{2}=1\right)$ com a altura. A queda na interceptação da luz com o aumento do IAF foi explicada pelas modificações nas características morfológicas das pastagens representadas pela altura, quantidade de massa seca residual e IAF. 
A inter-relação entre essas características morfológicas podem ocorrer de forma diferente conforme a época do ano, estágio de crescimento e idade da planta. Outros aspectos da planta que afetam a taxa de interceptação de luz no dossel foram apontados por Pedreira et al. (2001).

Esses autores indicaram o angulo foliar, a distribuição vertical das folhas e a densidade da forragem no perfil do dossel como características morfológicas das pastagens que afetam a taxa de interceptação de luz no dossel.

Do mesmo modo, Fagundes et al. (1999) avaliou o efeito da altura de pastejo (5, 10, 15 e $20 \mathrm{~cm}$ ) sobre o IAF e a interceptação luminosa em pastagens formadas com três espécies de Cynodon spp. (Coastcross, Florakirk e Tifton 85). Esses autores determinaram que o IAF e a interceptação de luz foram maiores nos pastos manejados mais altos o que foi associado, provavelmente, æ̀s folhas maiores e dispostas de forma mais horizontal, reduzindo a quantidade de luz propagada ao longo do perfil do dossel (Pedreira et al., 2001).

Pedreira et al. (2001) apontaram que a distribuição e densidade das folhas nas camadas do perfil do dossel afetam a taxa de interceptação da luz. Assim, uma grande quantidade de folhas confinadas em uma estreita camada do perfil do dossel, determinará uma alta sobreposição de folhas e, consequentemente, alto grau de auto sombreamento e menor interceptação de luz.

Plantas com angulo foliar mais eretos e folhas mais distribuídas ao longo do perfil são mais eficientes quanto a interceptação de luz no dossel pois a superfície de captação é maior e a melhor distribuição de folhas no perfil permite recuperar a luz que foi refletida por outros tecidos ou folhas do dossel (Pedreira et al., 2001)

A desfolha ou corte da pastagem reduz a taxa de assimilação de carbono pela planta, mas essa redução nem sempre é proporcional a redução do IAF pois essa relação dependerá da proporção de tecido removido; capacidade 
fotossintética das folhas remanescentes e do sombreamento provocado pelas plantas vizinhas (Lemaire, 2001).

Em revisão sobre o assunto, Sbrissia \& Da Silva (2001) indicaram que o nível de redução na capacidade fotossintética da pastagem após a desfolha não é proporcional à redução provocada pela diminuição do IAF quando as folhas novas são removidas e permanecem as folhas velhas que estavam sombreadas. Por outro lado em pastejo leniente a redução na assimilação de carbono será menor se o IAF pós pastejo manter elevada proporção de folhas novas ou em alongação. Essa diferença deve-se ao fato de que a capacidade fotossintética das folhas velhas é inferior àdas folhas novas.

Alterações morfológicas na estrutura da planta forrageira podem ocorrer para que a planta adapte-se ao novo ambiente provocado pela desfolha e, assim, garantir a sobrevivência da espécie na comunidade. Essas mudanças são conhecidas como plasticidade morfológica ou fenotípica, definida por Lemaire \& Agnusdei (1999) como uma alteração progressiva e reversível nas característica morfológicas das plantas.

Uma vez submetida ao estresse, provocado pela desfolha, a planta inicia o processo de adaptação através de mudanças fisiológicas a curto prazo para tentar manter seu equilíbrio na comunidade. Se o estresse continuar e/ou aumentar, respostas fisiológicas deixam de ser efetivas e precisam ser combinadas com respostas morfológicas, caracterizando a natureza dinâmica das alterações, modificando a estrutura do pasto e da forragem disponível para o animal.

Além da densidade da biomassa interferir na interceptação luminosa ela também desempenha papel importante no consumo do animal (Stobbs, 1973). Esses aspectos também foram abordados por Pedreira et al. (2001) e Carvalho et al. (2001a).

A densidade de forragem em pastagem de capim Elefante anão manejada em sistema rotacionado com ofertas de forragem de 12 para 9 (alta), de 9 para 6 (média) e de 6 para 3 (baixa) kg de (MS)/100 kg PV, por ocasião da 
entrada e saída dos animais dos piquetes, respectivamente, foi de 62, 49 e 60 $\mathrm{kg} \mathrm{MS} / \mathrm{ha} / \mathrm{cm}$ de massa seca verde, respectivamente (Silva et al., 1994). Embora a variação na densidade de forragem tenha sido pequena, observou-se que as lâminas foliares concentravam-se nas camadas de 40 a $80 \mathrm{~cm}$ e 40 a 60 $\mathrm{cm}$ nos piquetes mantidos sob alta e baixa oferta de forragem, respectivamente. Além desse aspecto, o peso das lâminas foliares decresceu do estrato superior para o inferior sob alta oferta de forragem, mas foi praticamente estável nos diferentes estratos quando o manejo foi realizado com baixa e média oferta de forragem. Esses resultados suportam o trabalho de Almeida et al. (2000a) que verificaram redução no número de nós e comprimento dos entrenós com redução na oferta de forragem. Do mesmo modo Peternelli et al. (2000) indicam que a relação folha/haste em pastos de capim Tanzânia diminui com o aumento da altura de pastejo entre 24,6 a $71,4 \mathrm{~cm}$. Aguiar et al. (2001) trabalhando com capim Tanzânia também observaram que a relação folha/haste diminuía quando o massa de forragem no resíduo pós pastejo aumentava de 1000 para $4000 \mathrm{~kg} / \mathrm{ha} \mathrm{MSV}$.

Pode se inferir que a interceptação luminosa máxima pelas plantas mantidas sob elevada pressão de pastejo ocorra antes do que nas plantas submetidas a baixa pressão de pastejo. Além desse aspecto, o aproveitamento da planta forrageira submetida a baixa pressão de pastejo pode ser menor porque as folhas sendo maiores nos estratos superiores das plantas pode estar relacionada como aparecimento de hastes uma vez que folhas maiores correspondem à bainhas de tamanho proporcional (Davies, 1988). Por outro lado, as plantas submetidas à pressões de pastejos mais baixas poderiam acumular matéria seca verde mais tempo uma vez que as folhas do estrato superior são maiores do que a dos estrato inferior.

Por outro lado, Rego et al. (2001b), determinaram em capim Tanzânia, resposta quadrática entre a altura de pastejo $(24$ a $78 \mathrm{~cm})$, número de nós, comprimento do entre nós, altura do meristema apical e IAF em função da época do ano (janeiro a maio de 1999). Esse fato sugere que a interação entre 
altura do pastejo e época do ano, associada ao sucessivos pastejos, pode alterar a estrutura da planta. Trabalhos semelhantes publicados por Paiva et al. (2001) e Bortolo et al. (2000a) indicaram o efeito negativo e linear do avanço do período experimental sobre a relação folha/haste devido ao aumento do material morto e senescente da planta.

Alterações na relação folha/haste são possíveis de serem previstas como estudo das variáveis propostas por Pontes et al. (2000), Davies (1988), Lemaire \& Chapman (1966), Carvalho et al. (2001a), Cano et al. (2001a) e Barbosa et al. (2001a).

Pontes et al. (2001) trabalhando com azevém observaram que o tamanho das folhas eram maiores como aumento da altura de pastejo $(5,10,15$ e $20 \mathrm{~cm}$ ). Essa resposta foi apontada pelos autores como sendo resultado do efeito do manejo sobre às características morfológicas taxa de alongação das folhas (TAF) e tempo de duração de alongamento das folhas (TDA).

Entretanto a relação folha/haste $(0,05$ a 0,45$)$ em pastagens formadas de Coastcross-1 (Cynodon dactylon (L.) Pers) aumentaram linearmente com a elevação da altura de pastejo que variou de 4,7 a $23,3 \mathrm{~cm}$, respectivamente, para a menor (1626 kg/ha MS) e maior massa de forragem no resíduo (3965 $\mathrm{kg} / \mathrm{ha}$ MS) (Bortolo et al., 2000a) e negativamente com a época do ano (janeiro a fevereiro de 1998). Essa relação linear foi associada ao aumento na participação das folhas na planta com a elevação da altura pois a fração haste permaneceu praticamente inalterada. A queda da relação folha/haste ao longo do período experimental foi, segundo os autores, associada à redução da biomassa residual e aumento na participação de material morto que ocorreu com o avanço do experimento.

Paiva et al. (2001) também observaram um aumento na participação de material morto e senescente na planta com o avanço do período experimental (janeiro a outubro de 1999) e com o aumento da oferta de forragem (3,3; 4,1 e $4,9 \mathrm{~kg} \mathrm{MS} / 100 \mathrm{~kg}$ de PV). As quantidades de folhas e de haste diminuíram nos pastejos, no entanto, a participação de folhas foi sempre superior ao da haste. 
Fatores determinantes do tamanho da folha (TF) segundo esquema proposto por Lemaire \& Chapman (1996) apresentado na Figura 1, são a (TAF) e a taxa de aparecimento de folhas (TAPF). Enquanto a TAF está diretamente associada com o TF as folhas de menor tamanho são associadas a maior TAPF

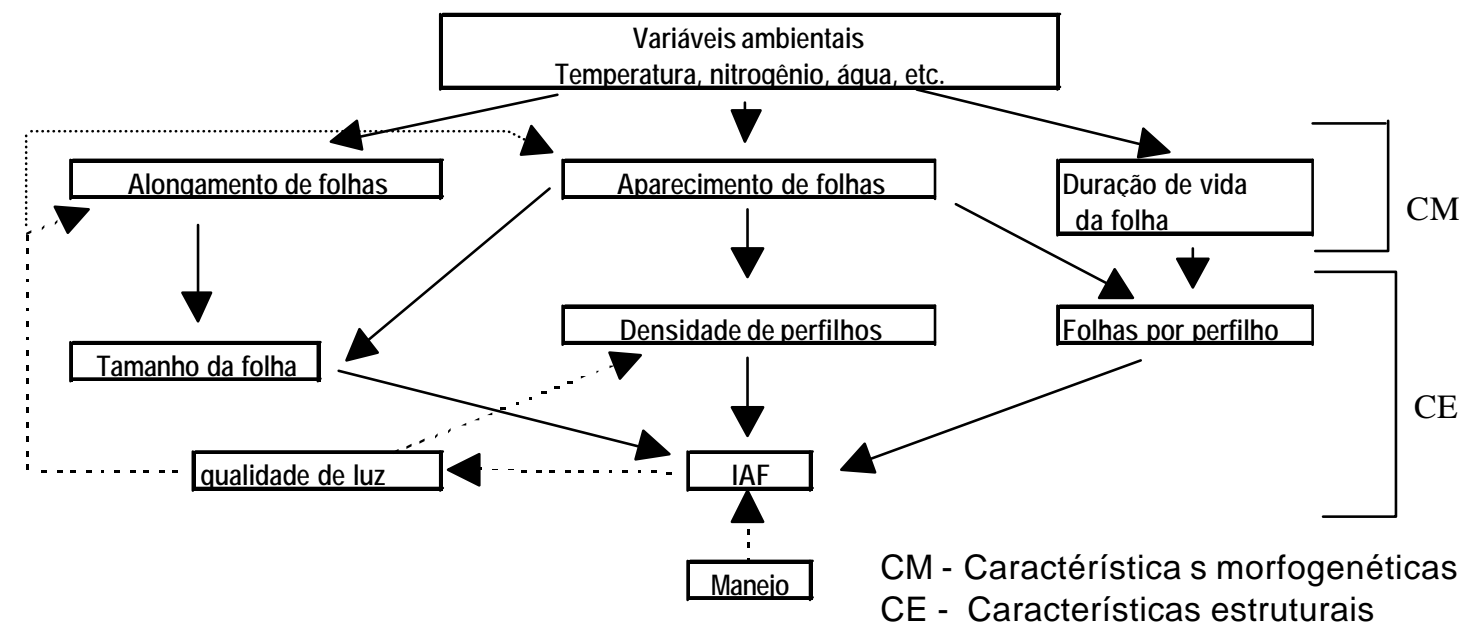

Figura 1- Relações entre as características morfogenéticas e estruturais da pastagem (Fonte: Lemaire \& Chapman, 1996)

Pela Figura 2, apresentada por Lemaire \& Agnusdei (1999), permite concluir que existe uma elevada correlação entre a medida direta do TF e a calculada em função da TAF e TAPF conforme a eq. (1).

Tamanho da folha $=$ a. TAF/TAPF

O parâmetros "a" significa o número de folhas crescendo simultaneamente no mesmo perfilho. 


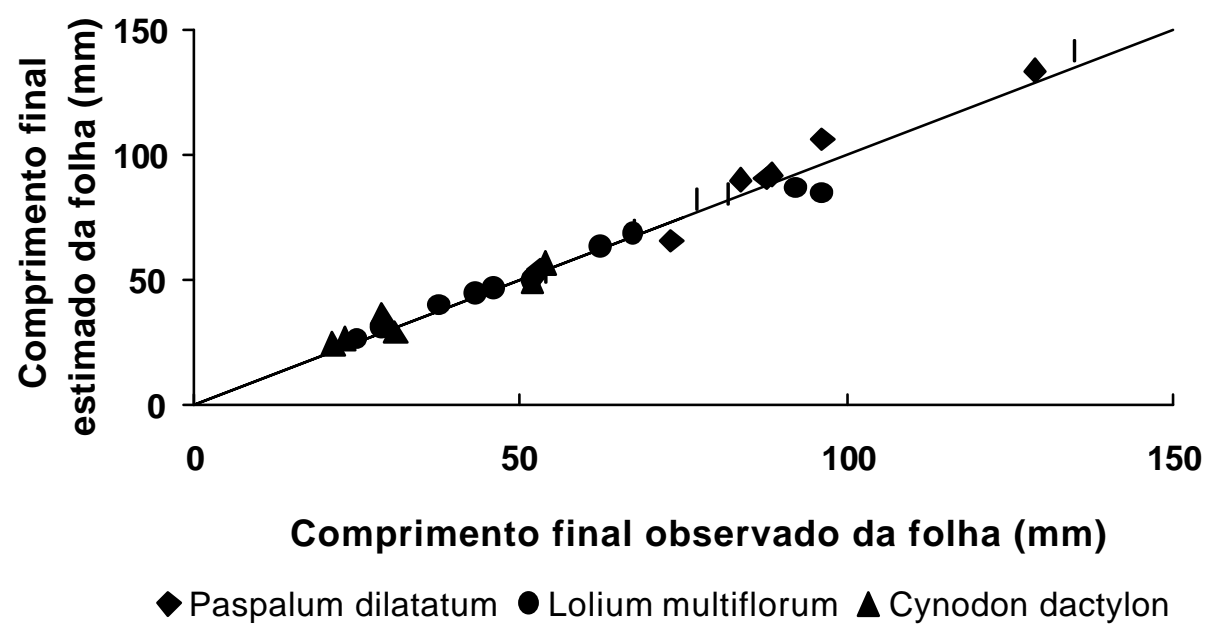

Figura 2 - Relação entre o comprimento final estimado da folha pela eq. (1) e o os valores observados para diferentes espécies nos Pampas Argentinos (Fonte: Agnusdei, 1999 citado por Lemaire \& Agnusdei, 1999).

Outro fator que interfere com a taxa de aparecimento de folhas e consequentemente com o seu tamanho é o comprimento do tubo de bainhas por onde elas emergem. A extensão do crescimento é fortemente retardada quando as folhas emergem no sentido da luz, sugerindo que essa resposta pode ser mediada pelo fitocromo (Davies 1988). Se o tubo da bainha for deixado intacto as folhas emergentes serão relativamente longas e aparecem mais vagarosamente do que em pastagem que houve a desfolha.

Portanto o TF também esta associado ao tamanho da bainha, pois quanto maior o comprimento da bainha maior será a fase de multiplicação celular e por mais tempo a folha em expansão ficara protegida da luz direta (Davies et al., 1983).

Desse modo podemos considerar que o comprimento da folha é uma característica morfológica plástica da planta à intensidade de desfolha e ela é considerada como um comportamento estratégico da planta para escapar ao 
pastejo (Lemaire \& Chapmam, 1996). Os resultados obtidos nos trabalhos de Carvalho et al. (2001a); Cano et al. (2001a) e Barbosa et al. (2001a) dão sustentação a essa processo pois as plantas apresentaram folhas menores com o aumento da intensidade de desfolha.

Entretanto folhas menores podem resultar na queda da capacidade de interceptação da luz (Pedreira et al., 2001) diminuindo a produção e o poder de competição sobre plantas invasoras (Faria, 1994). Uma forma de melhorar o seu status dentro da comunidade e o nível de interceptação luminosa seria, como discutido acima, modificar angulo de crescimento das folhas ou perfilhos.

Outra maneira das plantas no dossel desfolhado aumentar o IAF seria incrementando o número de perfilhos na comunidade já que outra maneira de ajustar o IAF seria aumentando o número de folhas por perfilho porém, essa característica da planta é pouco alterada pelo meio (Nabinger \& Pontes, 2001). Essa afirmação esta condizente com os resultados dos trabalhos de Cano et al. (2001a) e Almeida et al. (2000a) onde o número de folhas total por perfilho não foi alterada em função da altura de pastejo;

O trabalho de Cano et al. 2001b mostra o efeito linear e quadrático (DP = $\left.0,2793+0,06697 \mathrm{~A}-0,0559 \mathrm{P}+0,00043 \mathrm{P}^{2}\right)$ da altura $(\mathrm{A})(22,4 \mathrm{a} 65,7 \mathrm{~cm})$ e do período $(P)$ de pastejo (janeiro a abril de 2000), respectivamente, com a densidade de perfilhos (DP). Esse resultado esta de acordo com os obtidos por Meceli (1979) e Almeida et al. (2000a). O primeiro autor trabalhou com capim Colonião (Panicum maximum Jacq.) e obteve maior quantidade de perfilhos no corte a $15 \mathrm{~cm}\left(540 / \mathrm{m}^{2}\right)$ em relação ao corte com $30 \mathrm{~cm}$ do solo $\left(441 / \mathrm{m}^{2}\right)$.

No trabalho de Almeida et al. (2000a) a densidade de perfilhos reduziu de 250 para 192 perfilhos/touceira com o aumento na oferta de forragem (3,8 a $14,7 \mathrm{~kg}$ de lâmina verde/100 kg PV) ou da altura de pastejo. Entretanto a amplitude no numero de perfilhos por $\mathrm{m}^{2}$ (224 a 281) foram menores, mostrando que os estudos sobre perfilhamento, em pastagens que formam touceiras, devem contemplar a densidade de perfilhos a nível de touceira e por $\mathrm{m}^{2}$. Apesar de vários trabalhos mostrarem o efeito do manejo sobre $o$ 
perfilhamento, Cecato et al. (2000), trabalhando com cultivares e acessos de Panicum maximum Jacq. não observaram o efeito da altura de pastejo (20 e 40 $\mathrm{cm}$ ) sobre a densidade de perfilhos por touceira para os capins Tanzânia, Mombaça, Colonião e Tobiatã mas o efeito da altura foi observado nos capins Aruana e Centenário.

O diâmetro das touceiras (DT), no caso das plantas de crescimento cespitoso, ou ereto, também poderia ser considerada uma reação da planta æ̀s condições ambientais e/ou de manejo já que o DT esta negativamente e linearmente relacionada com a intensidade de pastejo (Almeida et al. 2000a). Estes autores, trabalhando com capim Elefante anão, determinaram que o DT cresceu de 21,0 para $42,8 \mathrm{~cm}$ quanto a oferta de forragem $(3,8 ; 7,5 ; 10,2$ e $14 \%$ do PV) e/ou na altura e/ou massa de forragem pós pastejo aumentaram. Esses três fatores estavam positivamente e linearmente relacionados.

Outra maneira da planta forrageira manter a sustentabilidade do sistema de produção poderia ser analisada através de modificações na taxa de ocupação da área pelas plantas (TO). Desse modo a TO estaria associada com processos de degradação de pastagens. Entretanto, ao relacionarmos a TO com o processo de degradação, a forma de crescimento das plantas (prostada, decumbente, ereta ou cespitosa) deve ser considerada na analise dessa relação. Por exemplo, em pastagens de Cynodon spp., quando mais próxima de $100 \%$ for a TO, melhor deverá ser o nível de estabelecimento da planta na área ou na comunidade de plantas. A porcentagem de solo descoberto em pastagem formada com Coastcross-1, decresceu linearmente (de 89,2 para 1\%), àmedida que aumentou a quantidade de forragem no resíduo (1978, 2130, 2545 e 3857 $\mathrm{kg} / \mathrm{ha}$ MS) e ao longo do período experimental (Bortolo et al. 2001a).

A TO da planta forrageira de hábito de crescimento cespitoso avaliada pela área basal da touceira foi determinada em sistemas intensivos de produção em pastagens de capim Elefante (Penninsetum purpureum Schum.) no Departamento de Produção Animal da Escola Superior de Agricultura "Luiz de Queiroz" por Martha Jr. et al. (1999). Esses autores indicaram 47,6\% como 
valor médio da TO sendo que a variação dos valores observados esteve entre 29 e 56\%. No sistema de manejo utilizado para uso dessas pastagens, essas TO parecem garantir a sustentabilidade do sistema uma vez que, essas pastagens estão sendo pastejadas por mais de 30 anos e, por vezes, com taxas de lotação média de 11 UA/ha no período de "verão" (Da Silva et al. 1996).

Do mesmo modo, no trabalho de Almeida et al. (2000a) a TO em pastagens de capim Elefante anão e a intensidade de manejo estiveram correlacionadas através de uma função quadrática. A TO neste experimento foi de 19,0; 54,4; 62,2 e 70,0\% para as massas seca verde de lâminas foliares residuais de $722 \pm 104 ; 1537 \pm 65 ; 2332 \pm 2$ e $2542 \pm 36 \mathrm{~kg} / \mathrm{ha}$, respectivamente. A TO nesta pesquisa foi considerada como sendo a área de sombreamento da touceira e não a área basal da touceira como consideraram Bortolo et al. (2001a) e Martha Jr. et al. (1999).

Por outro lado, a pesquisa de Perternelli et al. (2000) utilizando capim Tanzânia, também verificaram que a altura da pastagem foi correlacionada positivamente com a DT enquanto que a proporção de solo descoberto foi negativamente correlacionada. Essa mesma tendência foi observado no trabalho de Almeida et al. (2000a).

\subsubsection{Efeito do manejo da pastagem sobre o desempenho e produtividade animal}

A produção animal sob pastejo é influenciada pela qualidade da forragem disponível na pastagem. Segundo Mott \& Moore (1969) citados por Fahey Jr. \& Hussein (1999), a qualidade da forragem pode ser definida como produto entre o consumo e a digestibilidade da forragem, sendo, segundo os autores, o consumo mais importante entre os dois componentes.

Poppi et al. (1987) e Hodgson (1990) também consideram que a ingestão de matéria seca é o grande determinante da produção animal em pastagens. Mertens (1994) acredita que 60 a 90\% da variação na ingestão de energia 
digestível esta relacionada com a ingestão de alimentos pelo animal, enquanto que 10 a $40 \%$ está relacionada à digestibilidade da forragem. Entretanto a ingestão da forragem por animais em pastejo é também controlada por outros fatores relacionados ao animal, meio ambiente e a planta (Minson, 1990).

Os principais parâmetros das pastagens que estão relacionados ao controle do consumo de forragem são, segundo Poppi et al. (1987): a) quantidade total de forragem ( $\mathrm{kg} \mathrm{MS} / \mathrm{ha}$ ), b) quantidade de forragem verde $(\mathrm{kg}$ $\mathrm{MSV} / \mathrm{ha}$ ), c) altura de pastejo (cm), d) oferta de forragem ( $\mathrm{kg}$ de MS/kg de peso vivo (PV)) e e) massa de forragem do resíduo (MFR) (kg MS/ha). Entretanto fica difícil avaliar o efeito, por exemplo, da altura de pastejo sobre o desempenho animal ou produtividade, sem considerar os outros parâmetros, pois vários trabalhos na literatura (Almeida et al., 2000a; Almeida et al., 2000b; Carnevalli et al., 2000; Grasselli et al., 2000, Bortolo et al., 2001a; Bortolo et al. 2001b e Canto et al., 2001) mostram uma forte relação entre esses parâmetros, ou seja, conforme se eleva a altura de pastejo, concomitantemente é alterado os valores dos outros parâmetros como oferta de forragem, massa de forragem no resíduo, etc.

Na Figura 3, citada por Hodgson (1990), as relações entre altura da pastagem com consumo de matéria seca e desempenho animal ficam bem evidentes. $\mathrm{O}$ aumento na altura de forragem proporcionou melhora no consumo de matéria seca, entretanto com alturas menores de forragem associada a maiores quantidades é possível obter ganhos elevados de produção animal. Assim, com oferta de aproximadamente 2 e $4 \mathrm{~kg} \mathrm{MSV/dia} \mathrm{por} \mathrm{ovelha} \mathrm{foi}$ possível obter 200 e $400 \mathrm{~g} /$ dia de ganho de peso vivo (GPV) por animal quando a quantidade de forragem foi de 2500 e $1000 \mathrm{~kg} \mathrm{MS} / \mathrm{ha}$.

A disponibilidade de forragem tem sido relacionada com o consumo de matéria seca da pastagem pelos animais ruminantes (Gomide,1993), entretanto Hodgson (1990) indicou que a ingestão de forragem pelos animais aumenta em taxas decrescentes à medida que a oferta de forragem aumenta, atingindo um 
teto quando a oferta de forragem diária, expressa em MS, atinge valores próximos de 10 a $12 \%$ do PV do animal.

No trabalho conduzido por Ribeiro et al. (1997), com novilhos de corte em pastagens de capim Elefante anão, submetidos a quatro níveis de oferta de forragem (4, 8, 12 e $16 \mathrm{~kg}$ de MS de lâmina foliar verde/100 kg PV/dia), os autores observaram aumento linear no consumo de matéria orgânica (MO) de $2,5 \%$ a $3,7 \%$ do PV, quando a oferta de forragem aumentou. Esses autores perceberam também, conforme Hodgson (1990), que o consumo de forragem cresceu linearmente até na pressão de pastejo de $12 \%$ e acima desse valor houve redução do consumo.

Almeida et al. (2000b), utilizando animais cruzados (nelore $x$ charolês) de $165 \mathrm{~kg}$ de PV em pastagens de capim Elefante anão, registraram efeito quadrático entre oferta de forragem $(3,8 ; 7,5 ; 10,2$ e $14 \mathrm{~kg}$ de lâminas foliares secas verdes/100 kg PV) e GPV que foram de 0,83; 1,01; 1,04 e 1,03 $\mathrm{kg} / \mathrm{cab}$./dia, respectivamente.

Pelos resultados apresentados por Barbosa et al. (2001b) na Figura 4 verificamos também o efeito quadrático da oferta de forragem $(3,7,11$ e $15 \mathrm{~kg}$ de lâminas foliares secas verdes/100 kg PV) sobre o desempenho animal em pastagens formadas com capim Tanzânia. No caso da analise relativa a produção por área, os resultados mostram a tendência desse parâmetro diminuir com o aumento da oferta de forragem. Segundo o autor, a oferta de forragem para obter melhor resultado para a interação ganho por animal e por área seria de 8 a $11 \mathrm{~kg}$ de lâminas foliares secas verdes $/ 100 \mathrm{~kg} \mathrm{PV}$. No trabalho de Almeida et al. (2000b) a produção animal por área também diminui com o aumento da oferta de forragem. 

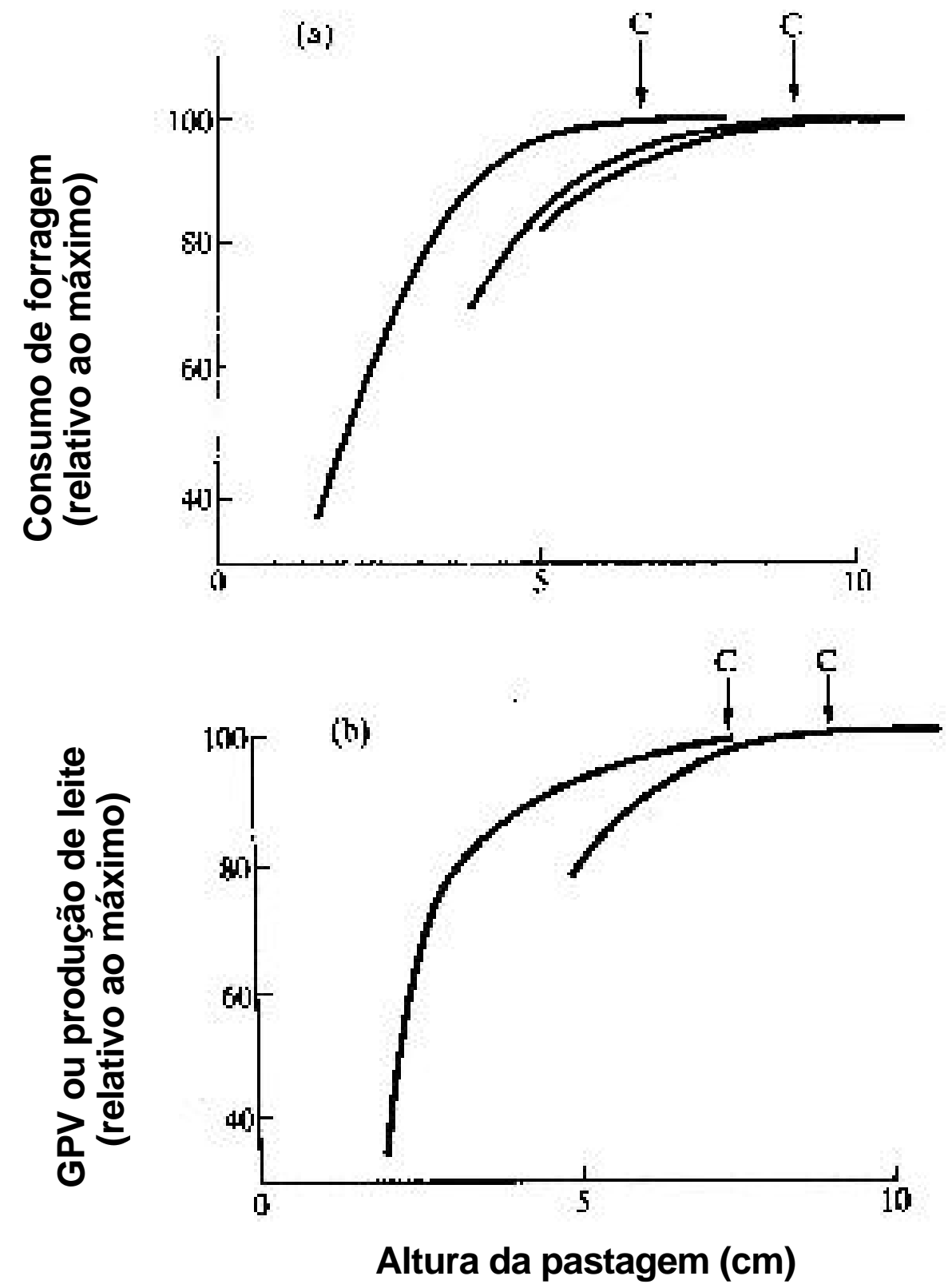

Figura 3 - Relações entre a altura da superfície da pastagem e ingestão de forragem (a) ou desempenho animal (b) de animais em pastejo sob lotação contínua (Hodgson, 1990). 


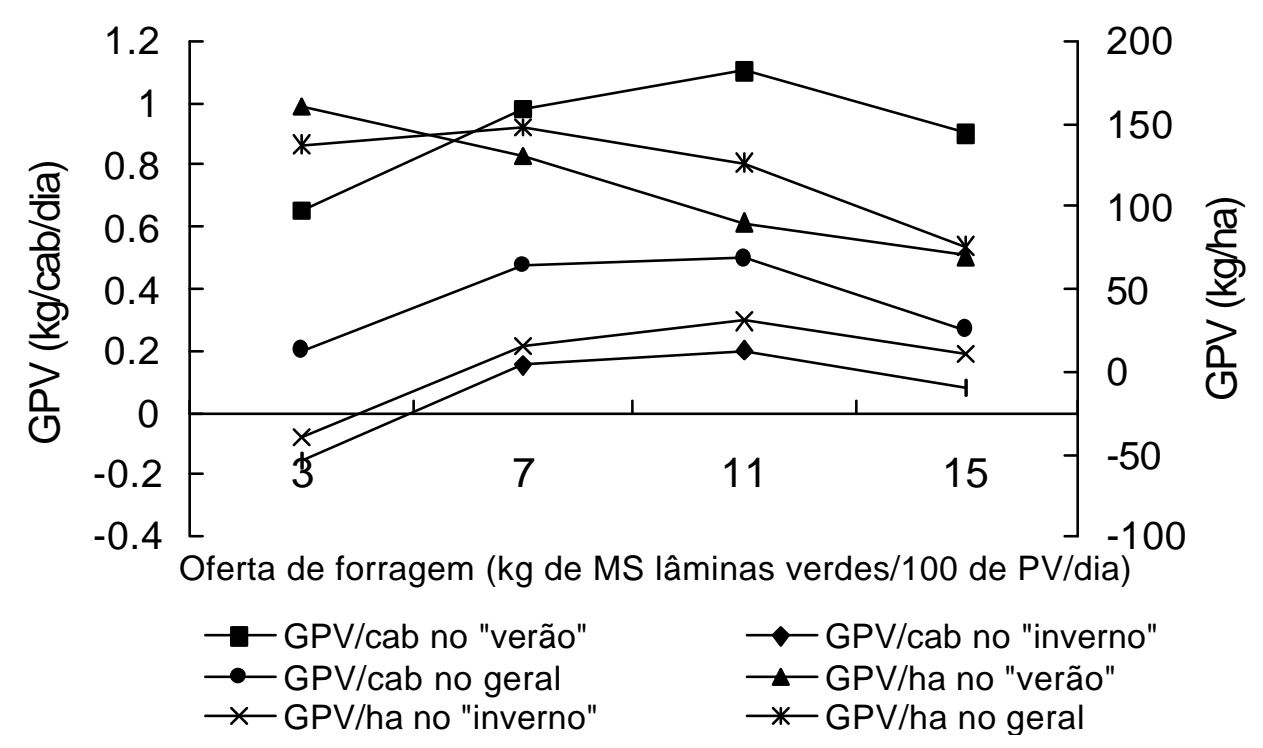

Figura 4 - Efeito da oferta de forragem em capim Tanzânia no ganho médio diário geral (GMDG), ganho por ha geral $(\mathrm{G} / \mathrm{haG})$, ganho médio diário no período verão-outono e inverno (GMDV e GMDI, respectivamente) e ganho por ha no verão-outono e inverno ( $G / h a V$ e $\mathrm{G} /$ hal, respectivamente) (Barbosa et al., 2001b).

Nos trabalhos de Almeida et al. (2000b) e Barbosa et al. (2001b) o máximo desempenho animal ocorreu em ofertas de forragem (7 a $11 \mathrm{~kg}$ de lâminas foliares secas verdes/100 kg PV) menores que os citados por Hodgson (1990) e Ribeiro et al. (1997).

A quantidade de MFR interfere significativamente no consumo animal conforme trabalhos realizados com gramíneas temperadas. Holmes \& Wilson (1984) citam consumos crescentes de 2,5 para $4,8 \%$ do PV a medida que 0 resíduo passou de 800 para $1800 \mathrm{~kg} \mathrm{MS} / \mathrm{ha}$, respectivamente. Esses autores também citam aumento no consumo de 2,4 para $3,2 \%$ do PV quando as massas de forragem nos resíduos aumentaram de 800 para $2000 \mathrm{~kg} \mathrm{MS} / \mathrm{ha}$, respectivamente. $O$ consumo de forragem aumentou até que a massa de 
forragem no resíduo atingiu o nível de $2000 \mathrm{~kg} \mathrm{MS} / \mathrm{ha}$ e estabilizando depois desse valor.

Outra característica estrutural na pastagem a ser considerada é a quantidade ou proporção de folhas. Sob condições de pastejo, além da altura, a relação folha/haste constitui-se como importante fator determinante do consumo (Stobbs, 1973; Stobbs 1975).

Segundo Minson (1990), a forragem selecionada pelos animais ruminantes em pastejo apresenta uma proporção maior de folhas do que a observada na pastagem, demonstrando uma grande preferência pelos animais por este órgão da planta. Isto ocorre porque as folhas apresentam uma composição química melhor do que a das hastes, em função da sua maior concentração de proteína e menor conteúdo de parede celular (Cowan \& Lowe 1998).

Entretanto, Balsalobre (1996) determinou, através de análises bromatológicas do resíduo de capim Elefante após os primeiros pastejos da primavera, que o valor nutritivo desse material não se constituiria em impedimento para o manejo adequado da pastagem.

Por outro lado, espera-se que o aumento na quantidade de massa de forragem no resíduo determine decréscimo na qualidade da forragem (Rego et al. 2001a), mas o mesmo pode não ocorrer quando a quantidade de massa de forragem no resíduo for menor devido a maior intensidade no perfilhamento e consequente renovação de tecidos na planta. Desse modo, pode-se obter interações importantes entre quantidade de resíduo, consumo de matéria seca e época do ano, que deverão interferir nas definições relativas ao manejo de forragens tropicais (Balsalobre 1996).

Entretanto, alguns trabalhos de pesquisa mostram que o aumento na oferta de forragem nem sempre melhora o consumo e/ou o desempenho animal. Hillesheim (1987) obteve o mesmo consumo de matéria seca $(1,4 \%$ do PV de novilhas holandesas) utilizando capim elefante sob pressões de pastejo de 4,8 e $12 \%$ do PV em MS e massa de forragem no resíduo entre 2680 a 
$4902 \mathrm{~kg} \mathrm{MS} / \mathrm{ha}$. Gomide et al. (2001) também não observaram vantagens do aumento da oferta de forragem de 4 para $8 \mathrm{~kg} \mathrm{MS} / 100 \mathrm{~kg}$ de PV sobre o consumo e produção de leite (média de $11 \mathrm{~kg} / \mathrm{dia}$ ) de vacas em pastagens de Braquiária decumbens. Segundo os autores, a ausência do efeito da maior oferta de forragem sobre o consumo pode se atribuída à estrutura menos favorável ao pastejo do dossel ofertado com maior quantidade de forragem e caracterizado por uma relação folha/haste mais estreita e com maior participação de material morto e nessa condição o comportamento ingestivo dos animais estaria sendo comprometido.

Variações observadas entre experimentos quanto as respostas de ingestão associadas as ofertas de forragem, parecem depender não somente da quantidade de forragem como pela categoria do animal que utiliza essa pastagem como aponta a Figura 5. O maior consumo por vacas de leite e de corte esta associado à uma maior disponibilidade de forragem do que é necessária para elevados desempenhos e/ou consumo de ovelhas. Poppi et al. (1987) no entanto, afirma que a disponibilidade e a oferta de forragem parecem atuar indiretamente na curva de resposta através das alterações em dois componentes estruturais da pastagem: altura e/ou densidade.

Hodgson et al. (1994) afirmam que as respostas dos animais ì variações na altura do relvado são mais consistente do que na quantidade de forragem, além disso, o parâmetro altura é aferido com mais facilidade do que a massa de forragem. Porém, para Gomide \& Gomide (2001) a densidade de folhas $(\mathrm{kg} / \mathrm{ha} / \mathrm{cm})$ determinada pela população de perfilhos e sua relação folha/haste é o principal responsável do comportamento ingestivo em pastagens tropicais.

Stobbs (1973), comenta que em pastagens de capim Braquiária (Brachiaria decumbens), capim Setária (Setária anceps cv. Kazangula) e capim de Rhodes (Chloris gayana), o tamanho do bocado cresceu com a densidade de biomassa e relação folha/haste, mas variou inversamente com a altura da vegetação. No entanto, Carvalho et al. (2001a) afirmam que essa evidência 
nunca foi suficientemente testada embora se reconheça que pastagens tropicais tem como característica a baixa densidade de forragem e uma elevada dispersão espacial de folhas que podem dificultar o processo de ingestão da forragem pelos animais (Carvalho et al. 2001b).

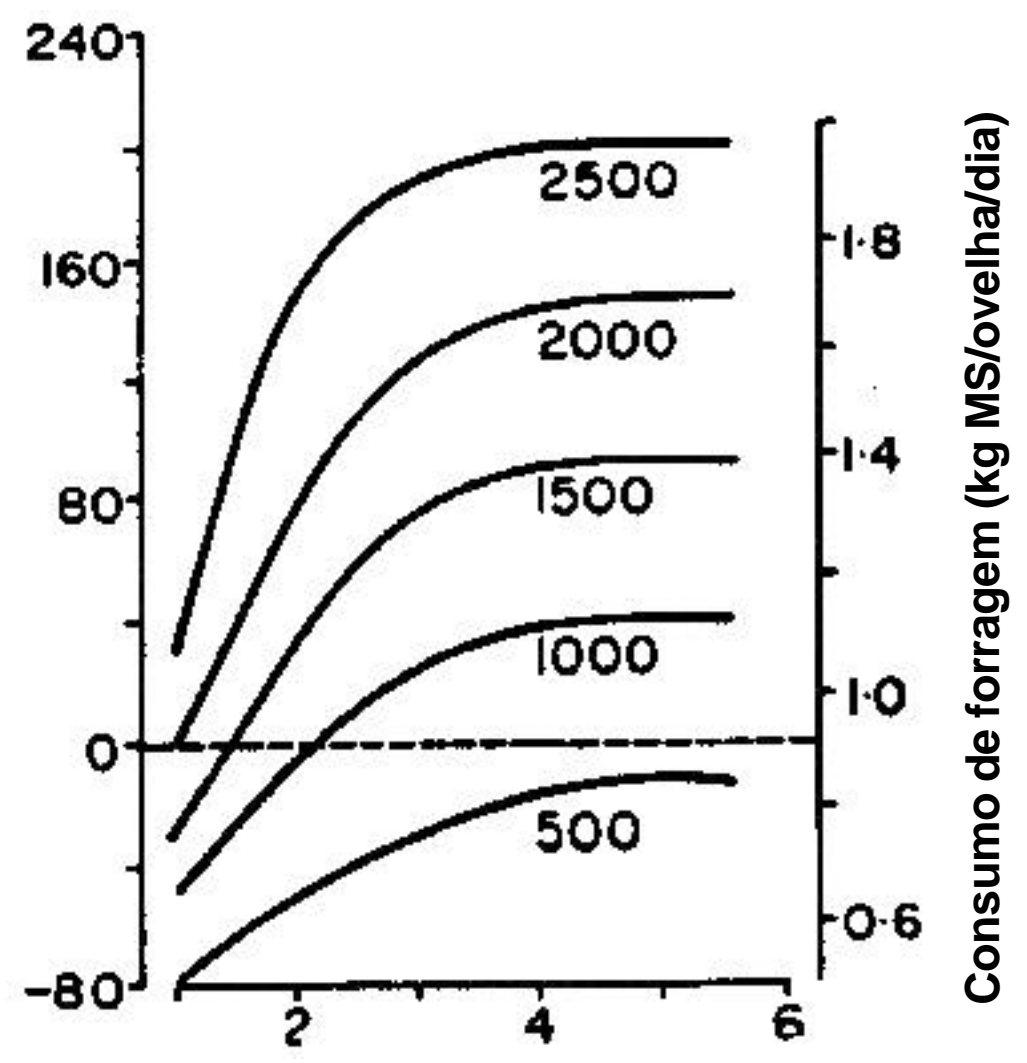

Oferta de forragem (Kg MSV/ovelha/dia) no eixo X e a disponibilidade de forragem (kg MSV/ha) no interior do gráfico

Figura 5 - Influência da oferta de forragem presente na pastagem no ganho de peso vivo de ovelhas em diferentes disponibilidades de forragem. (Hodgson, 1990)

Segundo Sollenberger \& Burns (2001), a densidade das pastagens formadas com gramíneas C4 estão dentro da amplitude das densidades das gramíneas C3 entretanto, esses valores estão próximos dos menores 
observados para essa amplitude. A densidade de folhas são, geralmente, menores nas gramíneas tropicais do que nas espécies temperadas. A variação na densidade da forragem ao longo do perfil do dossel (topo e base) é maior nas gramíneas tropicais, portanto o estudo do efeito da composição morfológica e química em vários estratos do perfil das pastagens devem estar mais relacionado com o desempenho animal nas espécies de gramíneas temperadas onde a distribuição vertical da densidade da pastagem é menor.

Burns et al. (1991) comenta que a forma como a folha é exposta ao animal é uma característica tão importante quanto a densidade e disponibilidade de folhas. Essa afirmação suporta as observações de Carvalho et al. (2001b) que determinaram um gasto maior de tempo por carneiros para manipularem o material apreendido nas pastagens de capim Tanzânia caracterizada por folhas maiores, do que nas pastagens mais baixas e com folhas menores.

Fica claro portanto, a importância da estrutura da pastagem, ou seja, da disposição espacial da biomassa na pastagem (Carvalho et al. 2001a) ou ainda da distribuição e arranjo da parte aérea das plantas na comunidade (Laca \& Lemaire, 2000) sobre o desempenho animal e da planta. $O$ equilíbrio entre a interface planta animal pode ser decorrente de várias reações de feed-back entre o comportamento animal e mudanças na estrutura da pastagem. O tempo necessário para que o equilíbrio ocorre ou seja novamente alterado é condicionado pelas condições do meio ambiente e pelo manejo empregado. $\mathrm{O}$ melhor ponto de equilíbrio seria aquele em que maximizassemos a produtividade por animal e da área sem comprometer o perenidade da pastagem. Portanto, é muito importante conhecer o comportamento dos animais e da planta sob pastejo em consequência das mudanças no meio ambiente ou no manejo, para então, definir-se a melhor estratégia de manejo e utilização da planta forrageira. 


\subsubsection{Efeito do manejo da pastagem sobre a eficiência de pastejo - perdas}

As perdas em sistemas de pastejo podem ser consideradas de várias formas como por exemplo, taxa de senescência, redução no valor nutritivo, danos físicos decorrente do pisoteio ou da queda da forragem durante os processos de escolha, apreensão e manipulação do alimento pelo animal em pastejo.

As perdas de forragem por ação física, podem assumir valores elevados como ocorreu no trabalho de Hilleshein (1987). Esse autor registrou perdas de forragem pela ação física de pastejo de 1003 a $1287 \mathrm{~kg}$ MS/ha (17 a 26\% da forragem disponível, respectivamente) em pastagens formadas com capim Elefante. Valores semelhantes de perdas de forragem (868 a $2825 \mathrm{~kg}$ MS/ha ou 12 a $37 \%$ da forragem disponível, respectivamente) também foram observadas por Balsalobre (1996) quando trabalhava com capim Elefante sob pastejo intensivo utilizando, principalmente, perfilhos basais. Esses valores de perdas indicam que a eficiência do pastejo pode ser seriamente comprometida se o nível de perda não for reduzido.

Hilleshein (1987) comenta que o aumento na pressão de pastejo contribuiu para diminuir a porcentagem de perdas de forragem em relação ao PV em pastagens formadas com capim Elefante a 30 anos. $O$ aumento da participação de folhas na planta e a redução da sua altura, contribuíram para diminuir essas perdas durante o pastejo. No trabalho de Hilleshein (1987), para cada $1 \mathrm{~cm}$ de aumento na altura do meristema apical da pastagem houve um incremento de 49,4 kg MS/ha de perdas causadas por ação física dos animais em pastejo.

Entretanto, no trabalho conduzido por Cecato et al. (2001) não foi constatado efeito da altura do pastejo sobre as perdas de forragem e acúmulo de liteira em $\mathrm{kg} \mathrm{MS} / \mathrm{ha}$ em pastagens formadas com capim Tanzânia.

Mudanças na estrutura da pastagem devem estar relacionadas às perdas de forragem pois a quantidade de material vegetal perdido variou ao longo das 
épocas do ano e com a estrutura da pastagem (Teixeira, 1998 e Hilleshein, 1987). No trabalho de Tosi (1999) com capim Tanzânia fica evidente essa relação pois as perdas de forragem, que variaram de 330 a $1900 \mathrm{~kg} \mathrm{MS} / \mathrm{ha}$, acompanharam a curva de produção da forragem ou seja quanto maior a produção do pasto maior foram as perdas. Entretanto, quando as perdas foram analisadas em relação à produção de forragem pré pastejo elas tiveram um comportamento inverso à produção de capim ou seja a porcentagem de perdas durante o período de "inverno" foi de $45 \%$ enquanto que no período de "verão" perdeu-se $14 \%$. 


\section{MATERIAL E MÉTODOS}

\subsection{Estabelecimento da área experimental}

O experimento foi desenvolvido no período de 30 de outubro de 1999 até 03 de janeiro de 2001 em um sistema rotacionado de pastagens irrigadas de capim Tanzânia (Panicum maximum Jacq. cv. Tanzânia) estabelecido na Fazenda Areão da Escola Superior de Agricultura "Luiz de Queiroz" - USP, localizada no município de Piracicaba/SP (580 m de altitude, $22^{\circ} 41^{\prime} 30^{\prime \prime}$ de latitude sul e $47^{\circ} 38^{\prime} 00^{\prime \prime}$ de longitude oeste). Esse experimento fez parte de um grupo de pesquisas coordenadas pelo projeto Temático "Avaliação de um sistema de produção animal sob pastejo em capim Tanzânia (Panicum maximum Jacq.) irrigado".

O delineamento experimental foi o de blocos completos ao acaso com três tratamentos e 4 blocos. Os tratamentos foram três intensidades de pastejo representadas pela massa de resíduo pós pastejo (T1 - 1000, T2 - 2500 e T3 $4000 \mathrm{~kg} / \mathrm{ha}$ de matéria seca verde (MSV)). No programa inicial, os tratamentos eram 1000, 2500 e $4000 \mathrm{~kg} \mathrm{MS} /$ ha pós pastejo. Entretanto, no final do segundo ciclo foi observado que as pastagens do T1 estavam em degradação refletindo na morte de plantas forrageiras e na infestação com plantas daninhas. A probabilidade dessas pastagens degradarem bem antes do término do período experimental era alta e para não correr o risco de comprometer os objetivos propostos no experimento, a partir do terceiro ciclo os T1, T2 e T3 passaram a ser 1000, 2500 e $4000 \mathrm{~kg} \mathrm{MSV/ha} \mathrm{pós} \mathrm{pastejo,} \mathrm{respectivamente.}$ 
A área experimental formada com capim Tanzânia era irrigada através de um sistema de pivô central e ocupava 4,8 hectares que foram divididos, com cerca convencional e elétrica, em 12 fatias de 0,4 ha em forma de "pizza" (Figura 6). Cada fatia foi subdividida em 3 piquetes com área iguais. Dessa forma, cada tratamento ocupava 12 piquetes, sendo 3 deles por bloco. Com essa divisão o ciclo de pastejo e os períodos de descanso e de ocupação foram de 36,33 e 3 dias, respectivamente. Os animais tinham acesso à àgua e sal mineral dentro dos piquetes.

A lotação animal foi ajustada conforme a produção de massa de forragem avaliada a cada ciclo de pastejo sempre no piquete do meio da "fatia de pizza" (piquete B). As condições climáticas durante o período experimental são apresentadas na Tabela 1.

O preparo do solo foi realizado através de uma gradagem aradora e duas gradagens niveladoras. Os terraços foram reformados com auxílio de um arado. A semeadura foi realizada em 17 de março de 1999 através de uma semeadora utilizada para o plantio de trigo ou aveia com os carrinhos de plantio espaçados a $17 \mathrm{~cm}$ entre si. Para o estabelecimento das pastagens foram utilizados 1,5 toneladas de calcário (PRNT $=65 \%$ ), $3 \mathrm{~kg} / \mathrm{ha}$ de sementes puras viáveis, 750 $\mathrm{kg} / \mathrm{ha}$ de superfosfato simples, $350 \mathrm{~kg} / \mathrm{ha}$ de cloreto de potássio e $75 \mathrm{~kg} / \mathrm{ha}$ de FTE-BR-12 cuja composição química esta na Tabela 2. Essa correção do solo tinha o objetivo de atingir os seguintes valores: $80 \%$ de saturação por bases; 30 $\mathrm{mg} / \mathrm{cm}^{3}$ de fósforo e $5 \%$ na de potássio da capacidade de troca catiônica (CTC) segundo recomendação de Corsi \& Nussio (1993).

O calcário foi distribuído antes da aração e o cloreto de potássio com o FTE foram aplicados no solo entre as duas operações de gradagens niveladoras. O superfosfato foi aplicado em linha, próximo a semente, durante a semeadura. Após 15 dias da emergência das plantas foi realizada uma adubação de cobertura com $100 \mathrm{~kg} / \mathrm{ha}$ de uréia. 
Tabela 1. Dados de temperatura e radiação solar medidos na estação meteorológica da ESALQ durante o período experimental.

\begin{tabular}{|c|c|c|c|c|c|c|}
\hline \multirow[t]{2}{*}{ Ano } & \multirow[t]{2}{*}{ Mês } & \multirow{2}{*}{$\begin{array}{c}\text { Radiação global } \\
\mathrm{cal} / \mathrm{cm}^{2} / \mathrm{dia}\end{array}$} & \multirow{2}{*}{$\begin{array}{l}\text { Insolação } \\
\text { horas/dia }\end{array}$} & \multicolumn{3}{|c|}{ Temperatura média diária $\left({ }^{\circ} \mathrm{C}\right)$} \\
\hline & & & & máxima & mínima & Média \\
\hline 1999 & OUT. & 453,94 & 6,98 & 28,48 & 15,36 & 21,92 \\
\hline 1999 & NOV. & 479,67 & 7,04 & 29,47 & 15,70 & 22,59 \\
\hline 1999 & DEZ. & 507,87 & 7,23 & 30,56 & 18,99 & 24,78 \\
\hline 2000 & JAN. & 463,99 & 6,37 & 30,22 & 19,09 & 24,65 \\
\hline 2000 & FEV. & 450,10 & 5,49 & 29,92 & 19,24 & 24,58 \\
\hline 2000 & MAR. & 410,52 & 5,42 & 29,68 & 18,53 & 24,10 \\
\hline 2000 & ABR. & 450,53 & 9,08 & 29,36 & 14,48 & 21,92 \\
\hline 2000 & MAI. & 347,32 & 7,36 & 26,64 & 11,19 & 18,91 \\
\hline 2000 & JUN. & 304,37 & 6,68 & 27,16 & 11,36 & 19,26 \\
\hline 2000 & JUL. & 320,42 & 6,47 & 24,71 & 8,83 & 16,60 \\
\hline 2000 & AGO. & 324,35 & 5,74 & 26,53 & 12,50 & 19,53 \\
\hline 2000 & SET. & 396,03 & 6,17 & 27,20 & 15,10 & 21,15 \\
\hline 2000 & OUT. & 479,61 & 7,20 & 32,07 & 17,99 & 25,03 \\
\hline 2000 & NOV. & 465,20 & 6,79 & 29,82 & 17,72 & 23,77 \\
\hline 2000 & DEZ. & 447,94 & 5,63 & 29,78 & 19,00 & 24,42 \\
\hline 2001 & JAN. & 508,90 & 7,43 & 31,90 & 19,60 & 25,75 \\
\hline
\end{tabular}

O pastejo de uniformização foi iniciado em agosto de 1999 e em seguida os pastejos foram definidos para acertar as intensidades de pastejo até que o período experimental pudesse ser iniciado em 30 de outubro de 1999.

Em alguns locais da área semeada foi necessário aplicar 2,4 D e glifosato para fazer o controle localizado das plantas daninhas de folhas largas 
e gramíneas, respectivamente. Os piquetes foram adubados durante todo 0 período experimental com $80 \mathrm{~kg} / \mathrm{ha}$ de $\mathrm{N}, 13 \mathrm{~kg} / \mathrm{ha}$ de $\mathrm{P}_{2} \mathrm{O}_{5}$ e $80 \mathrm{~kg} / \mathrm{ha} \mathrm{K}_{2} \mathrm{O}$ por pastejo (334 kg/ha 24 - 04 - 24).

Tabela 2. Concentração de micronutrientes no fertilizante FTE-BR12.

\begin{tabular}{cc}
\hline Micronutriente & Concentração (\%) \\
\hline Boro & 1,8 \\
Cobre & 0,8 \\
Ferro & 3,0 \\
Manganês & 3,0 \\
Molibdênio & 0,1 \\
Zinco & 9,0 \\
\hline
\end{tabular}

Após o primeiro ciclo de pastejo foram coletadas amostras de terra para acompanhar a evolução da fertilidade do solo. Para compor as amostras foram coletadas 12 sub-amostras para cada tratamento por bloco, sendo quatro subamostras por piquete (A, B e C - ver Figura 6). O resultado das análises químicas das amostras estão na Tabela 3.

Ao redor da área experimental foi estabelecido um sistema de pastejo rotacionado composto de 5 pastos formados com capim braquirão, capim elefante, tanzânia e capim angola. Esse sistema de pastejo ocupava cerca de 2,5 ha e foi estabelecido para manter os animais que foram utilizados para ajustar a carga animal na área experimental. Durante o período de "inverno" esses animais receberam suplementação com volumoso e concentrado. 
Tabela 3. Resultados de análises químicas de solo amostrado a $0-20 \mathrm{~cm}$ de profundidade por tratamento (média dos quatro blocos).

\begin{tabular}{|c|c|c|c|c|c|c|c|c|c|c|}
\hline Trat. & $\begin{array}{l}\text { M.O. } \\
\text { g.dm }\end{array}$ & $\begin{array}{l}\mathrm{S}-\mathrm{SO}_{4} \\
\quad \mathrm{mg} \cdot \mathrm{dn}\end{array}$ & $\begin{array}{r}P \\
m^{-3} \\
\end{array}$ & K & $\mathrm{Ca}$ & $\begin{array}{l}\mathrm{Mg} \\
\mathrm{Mmol} .\end{array}$ & $\begin{array}{l}\mathrm{H}+\mathrm{Al} \\
\mathrm{dm}^{-3}\end{array}$ & SB & $\mathrm{T}$ & $\begin{array}{l}\mathrm{V} \\
\% \\
\end{array}$ \\
\hline 1 & 25,2 & 30 & 20,2 & 4,9 & 46,7 & 23,7 & 35,2 & 75,3 & 110,5 & 65,5 \\
\hline 2 & 25,0 & 31 & 18,5 & 4,4 & 39,5 & 19,5 & 32,7 & 63,4 & 96,1 & 63,7 \\
\hline \multirow[t]{2}{*}{3} & 24,7 & 29 & 18,5 & 3,4 & 36,2 & 19,5 & 37,1 & 59,1 & 96,2 & 59,7 \\
\hline & & $\begin{array}{c}\mathrm{pH} \\
\mathrm{CaCl}_{2} \\
\end{array}$ & & B & $\mathrm{Cu}$ & $\begin{array}{c}\mathrm{Fe} \\
\mathrm{Mg} \cdot \mathrm{dm}^{-3}\end{array}$ & $\mathrm{Mn}$ & $\mathrm{Zn}$ & & \\
\hline 1 & & 5,2 & & 0,46 & 5,2 & 52 & 44,4 & 4,7 & & \\
\hline 2 & & 5,1 & & 0,49 & 5,1 & 40 & 48,6 & 5,7 & & \\
\hline 3 & & 5,0 & & 0,40 & 4,3 & 46 & 46,7 & 4,1 & & \\
\hline
\end{tabular}

O manejo da irrigação foi realizado tomando como referencia o potencial de água no solo cujo monitoramento foi feito por tensiômetros digitais de punção, instalados em 10 baterias de seis tensiômetros, nas profundidades de $10,20,40,60,80$ e $100 \mathrm{~cm}$. O potencial médio foi mantido em valores superiores a - 0,05 Mpa, sendo as irrigações realizadas quando os tensiômetros instalados a $20 \mathrm{~cm}$ indicavam valores médios na faixa de - 0,3 a - 0,4 Mpa de tensão de água no solo (Lourenço et al., 2001). 


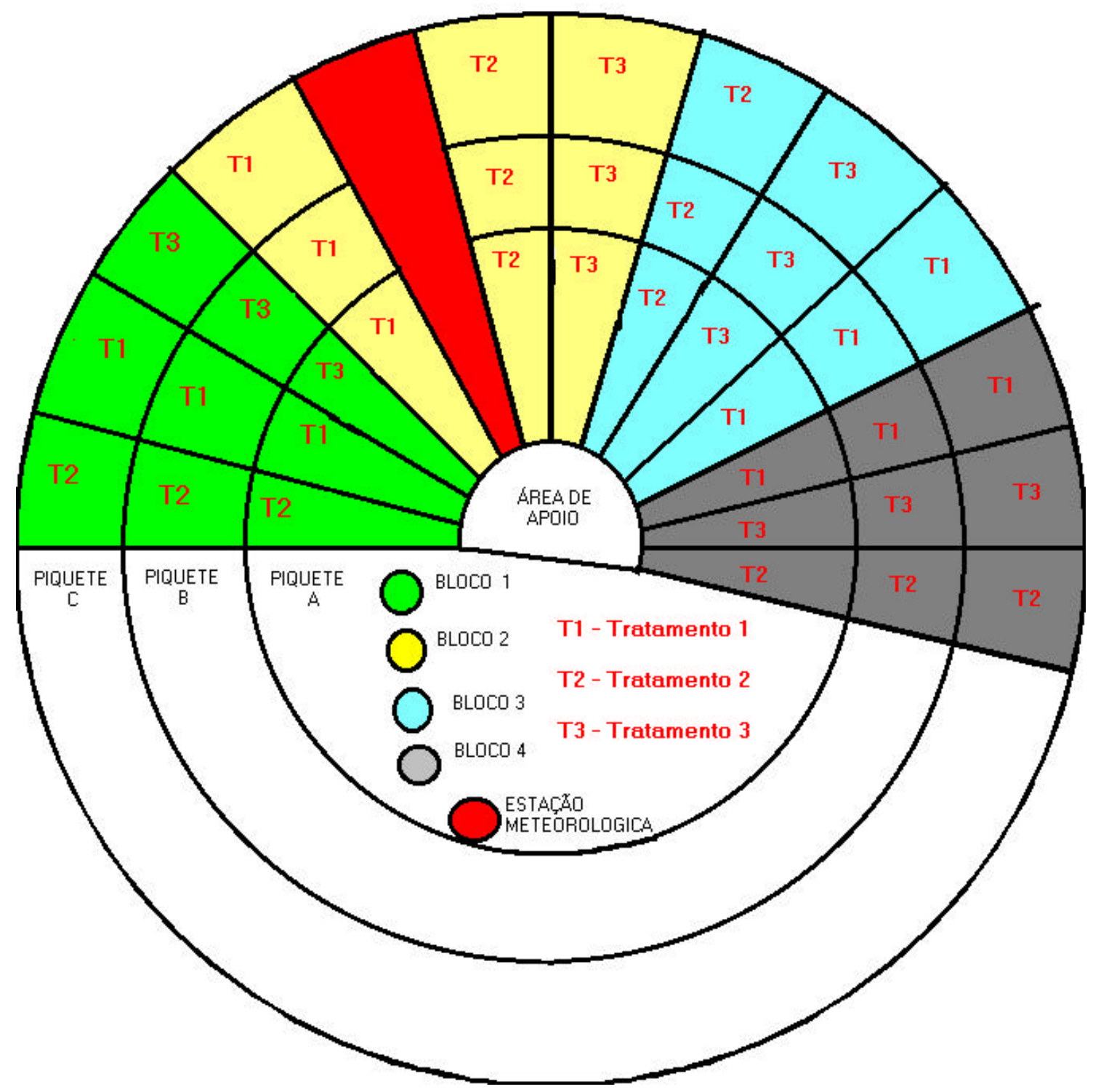

Figura 6 - Croqui da área experimental indicando as respectivas faixas dos tratamentos, blocos e dos piquetes $\mathrm{A}, \mathrm{B}$ e $\mathrm{C}$. 


\subsection{Material é métodos utilizados para a condução do experimento para determinar a metodologia a ser empregada para estimar a massa de forragem}

Foram conduzidos três pré experimentos para deteminar a melhor relação dimensão:formato da unidade amostral e a quantidade de amostras para avaliar a massa de forragem na área experimental uma vez que as gramíneas de hábito de crescimento cespitoso apresentam comportamentos diferentes em relação a área basal e área de sombreamento quando submetidos a diferentes intensidades de pastejo.

\subsubsection{Pré experimento 1}

O primeiro experimento foi realizado nas pastagens formadas, há cerca de 30 anos, com capim elefante no Departamento de Produção Animal da Escola Superior de Agricultura "Luiz de Queiroz". Esse experimento foi conduzido durante os meses de março a maio de 1999, enquanto estava sendo estabelecida a área experimental de capim Tanzânia na Fazenda Areão.

O experimento foi realizado em três conjuntos de piquetes denominados de $C(0,6$ ha), $D$ (2,0 ha) e F (2,2 ha), respectivamente e cada um deles foi considerado no delineamento estatístico como um bloco. Portanto em cada conjunto de piquetes foram aplicados os tratamentos referentes a relação dimensão-formato da unidade amostral $\left[0,25 \mathrm{~m}^{2}\right.$ quadrado $(0,25 \mathrm{Q}) ; 0,25 \mathrm{~m}^{2}$ retangular $(0,25 \mathrm{R}) ; 1,0 \mathrm{~m}^{2}$ quadrado $(1,00 \mathrm{Q}) ; 1 \mathrm{~m}^{2}$ retangular $(1,00 \mathrm{R}) ; 2,0 \mathrm{~m}^{2}$ quadrado (2,00Q); 2,0 $\mathrm{m}^{2}$ retangular (2,00R); 3,0 $\mathrm{m}^{2}$ quadrado (3,00Q) e $3,0 \mathrm{~m}^{2}$ retangular $(3,00 \mathrm{R})$ ] e os tratamentos referentes ao número de amostras (1 a 8). Os piquetes tinham cerca de $2000 \mathrm{~m}^{2}$ cada um e dessa forma os conjuntos C, D e F eram formados por 3, 10 e 11 piquetes, respectivamente. 
A moldura de ferro utilizada para demarcar os locais das coletas, foi construída com 1,41 m de largura por 2,45 m de comprimento dividida em duas partes para facilitar o manuseio. A moldura era subdividida de forma a estabelecer todas as relações dimensão-formato no seu interior (Figura 7). 0 formato retangular, independente da dimensão, apresentava a relação comprimento:largura igual a três.
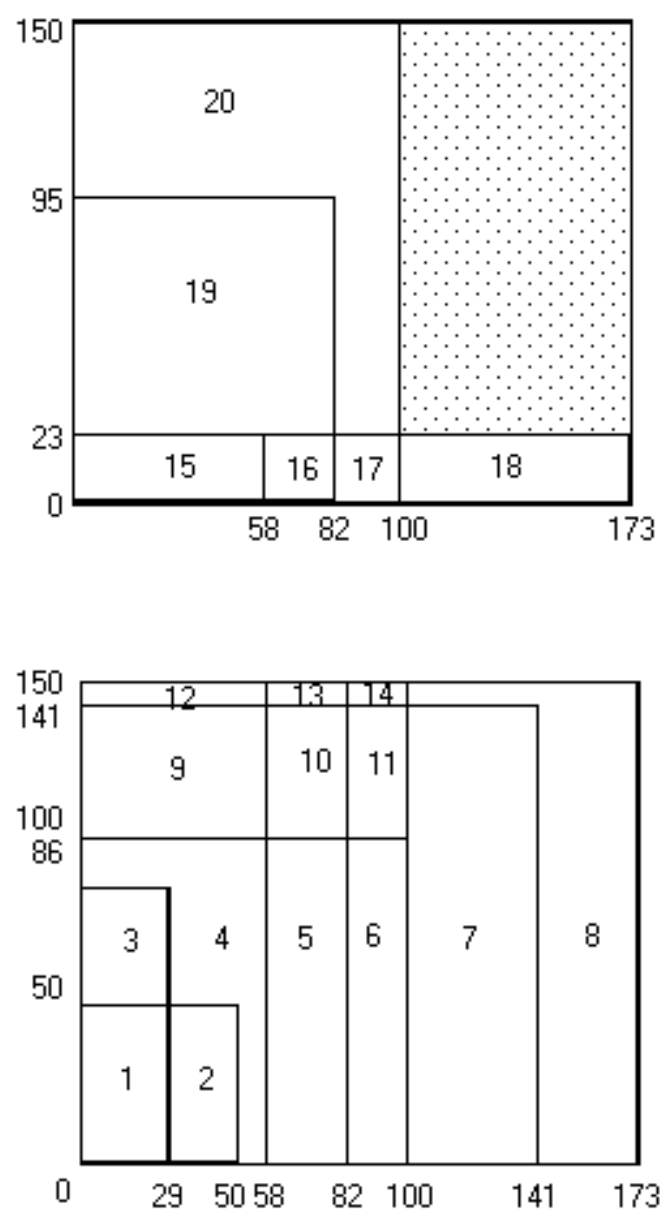

Figura 7 - Croqui das molduras indicando as divisões internas para proporcionar as relações dimensão-formato. Os valores nos eixos $X$ e $Y$ são expressos em $\mathrm{cm}$. 
Os locais das amostragens foram determinados aleatoriamente através do lançamento de uma parte da moldura no piquete. Tomando essa peça como ponto de referência, o restante da moldura era montada. Dessa maneira, a massa de forragem coletada na moldura que representava 0,25Q (áreas 1 e 2 da Figura 7) foi utilizada, por exemplo, para compor a amostra referente ao tratamento 1,00Q (áreas 1, 2, 3, 4, 5 e 6 da Figura 7).

O capim foi cortado a $5 \mathrm{~cm}$ do nível da superfície do solo. Nesse experimento não foi determinado o teor de matéria seca da forragem portanto os valores analisados foram expressos em matéria original.

\subsubsection{Pré experimentos 2 e 3}

Os pré experimentos 2 e 3 foram executados no período de 22 de setembro a 29 de outubro de 1999 nas pastagens formadas com o capim Tanzânia na Fazenda Areão. Nesses experimentos, os tratamentos de $3 \mathrm{~m}^{2}$ foram eliminados e os tratamentos referentes ao número de amostras passou de 8 para 9. Essas alterações foram feitas em decorrência dos resultados obtidos no pré experimento 1. Além desse aspecto, a quantidade de blocos passou de três para quatro pois o delineamento estatístico do experimento com o pasto de Tanzânia irrigado foi estabelecido com quatro blocos. Em cada bloco foram coletadas nove amostras sendo três amostras para cada um dos piquetes $\mathrm{A}$ (Figura 6).

A diferença entre os pré experimentos 2 e 3 foi o momento da amostragem. No pré experimento 2 as amostras foram realizadas antes do pastejo enquanto que no pré experimento 3 a coleta foi feita após os pastejos.

O primeiro pastejo na área foi realizado no período de 16 de agosto a 21 de setembro de 1999 e nesse pastejo foi feita a uniformização das pastagens. A condução dos pré experimentos 2 e 3 foi realizada durante o segundo pastejo 
(23 de setembro a 30 de outubro de 1999). Os tratamentos T1, T2 e T3 também foram aplicados no segundo pastejo, no entanto, somente a partir do terceiro pastejo iniciou a coleta dos dados do experimento principal.

O delineamento utilizado nos três pré experimentos foi de blocos completos em esquema fatorial, em que, os fatores foram número de amostras e relação dimensão-formato. Foi realizado uma análise de variância seguindo os resultados do teste $\mathrm{F}$ e as médias comparadas pelo teste $\mathrm{t}$-student.

\subsection{Determinação da massa de forragem, perdas, altura e da relação entre as frações folha verde, haste verde e material morto}

Em função dos resultados dos pré experimentos 1,2 e 3 a determinação da massa de forragem nos piquetes foi feita através do corte, a 5 $\mathrm{cm}$ da superfície do solo, das plantas que estavam delimitadas por cinco molduras de $1 \mathrm{~m} \times 1 \mathrm{~m}$ (unidades amostrais) por piquete. As unidades amostrais, ou seja as molduras de ferro de $1 \mathrm{~m} \times 1 \mathrm{~m}$, foram locadas nos piquetes de forma sistemática, através de uma linha transecta, para evitar que, ao longo do período experimental, ocorresse a sobreposição das unidades de amostragem e dessa forma evitaríamos que o efeito do corte da forragem no ciclo anterior afetasse a estimativa da massa de forragem do próximo pastejo.

A Figura 8 é um croqui de como foram marcados os locais para estimar a massa de forragem pré pastejo, pós pastejo e perdas. As amostras foram coletadas sempre no piquete $B$ de modo que representasse a produção de forragem da fatia de "pizza" ou seja dos piquetes A, B e C. 


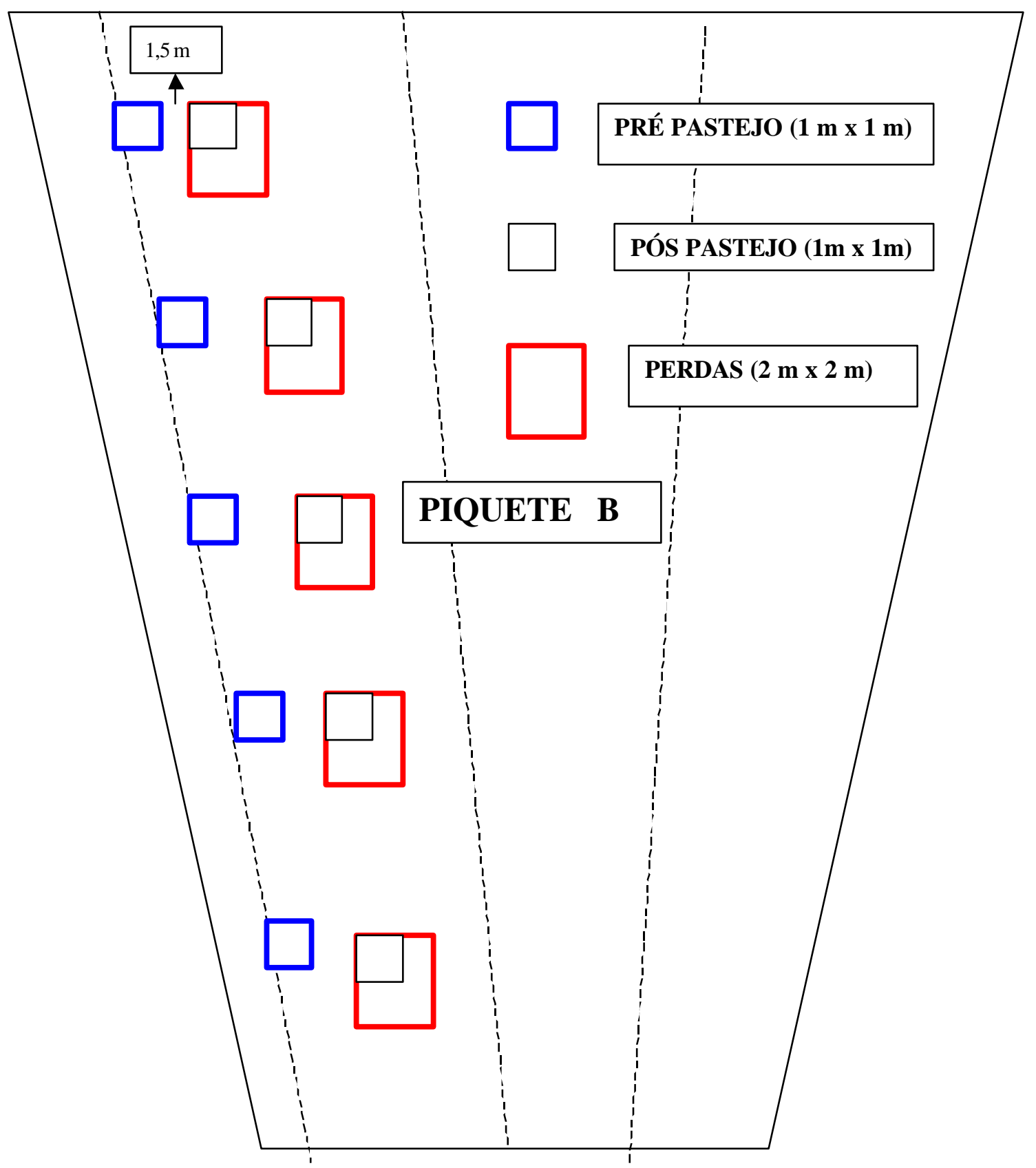

Figura 8 - Croqui das linhas transectas para orientar nas amostragens de forragem para avaliação da produção de massa no pré, pós pastejo e das perdas de forragem.

As áreas de amostragens para estimar a massa de forragem no pré e pós pastejo, as perdas pelo pastejo e as relações entre as frações folha verde, 
haste verde e material morto, eram demarcadas antes da entrada dos animais nos piquetes. As unidades de amostragens para determinar as perdas eram limpas de tal forma que, todo material que estava solto sobre o solo era retirado antes dos animais iniciarem o pastejo.

As molduras utilizadas para estimar a massa de forragem tinham uma das faces abertas para facilitar sua colocação no local marcado. Antes do corte da forragem (pré e pós pastejo), era medida a altura média das plantas em quatros pontos equidistante de forma que, cada ponto representasse um quadrante da unidade amostral (Figura 9).

A altura era medida com o auxílio de uma trena presa a um haste de ferro de 1,5 metros de comprimento. A altura era a distância compreendida entre a superfície do solo e o ponto de inflexão médio das folhas mais altas, que estavam dentro do mesmo quadrante.

Em cada unidade de amostragem era feita, antes do corte, uma avaliação visual da massa de forragem por cerca de três a cinco pessoas. Essas avaliações eram continuamente calibradas através dos pesos obtidos, logo em seguida àavaliação visual, com balança de ponteiro com precisão de 50 gramas.

A massa de forragem coletada era novamente pesada no laboratório usando uma balança digital com precisão de 10 gramas e foi essa pesagem utilizada na análise estatística. Após essa segunda pesagem três amostras eram coletada para: a) determinar o teor de matéria seca da planta toda em estufa regulada para manter $55^{\circ} \mathrm{C}$ de temperatura por no mínimo 96 horas, b) separar as frações lâmina foliar verde, hastes verde e material morto e c) estimar a distribuição vertical da massa de forragem ao longo do perfil da pastagem como descrito no item 3.5. Foi considerado como lâmina foliar verde as lâminas com menos de $50 \%$ de tecido senescente mais as folhas em expansão. Os materiais folhas, hastes e material morto separados na amostra eram pesados e depois mantidos em estufa a $55^{\circ} \mathrm{C}$ por no mínimo 96 horas para determinar o teor e quantidade de material seco. 


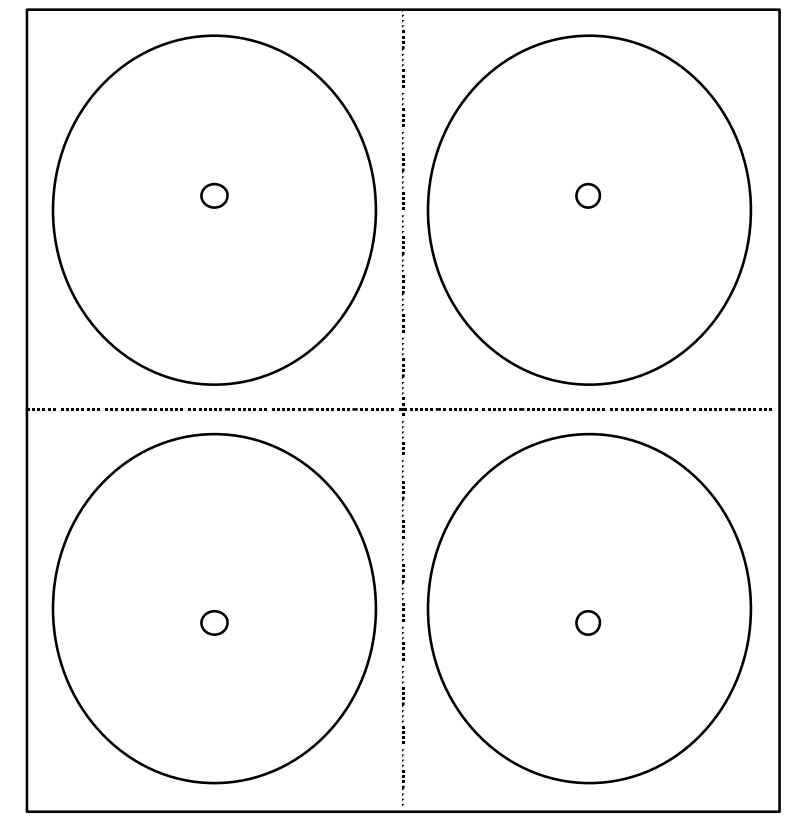

○ Local onde são medidas as alturas das plantas

Figura 9 - Croqui indicando os locais de onde são medidas as alturas das plantas no interior das molduras de $1 \mathrm{~m} \times 1 \mathrm{~m}$ usadas para avaliar a massa se forragem.

A coleta das amostras para estimar a perda de forragem pelo pastejo (todo material solto sobre o solo e preso na planta mas danificados pelas ações dos animais - Hilleshein, 1987) foi realizada no piquete B em cinco locais de $4 m^{2}(2 m \times 2 m)$ por tratamento.

O material coletado era conduzido para o laboratório e pesado. Desse material era retirada uma amostra por unidade amostral para determinar o teor de matéria seca. A partir do terceiro ciclo outra amostra, que representava as cinco molduras, passou a ser coletada para determinar a participação de folhas, haste e material morto na amostra da forragem perdida.

Além da altura das plantas medidas no interior de cada moldura também foram tomadas 30 medidas de altura em cada um dos piquetes ( $A, B$ e $C$ ) antes 
e após os pastejos. Nos piquetes B a altura das plantas também foi medida durante o período de ocupação (pré, primeiro dia, segundo dia e pós pastejo). Os locais onde as alturas eram medidas nos piquetes foram definidos, previamente, para que as medidas da altura das plantas ficassem bem distribuídas nos piquetes. Além disso, a definição dos locais tinha o intuito de padronizar os pontos de coleta entre as pessoas da equipe pois, essas medidas de altura não eram realizadas sempre pela mesma pessoa como aconteceu nas tomadas da medidas da altura das plantas que estavam no interior das molduras utilizadas para estimar a massa de forragem.

\subsection{Manejo das pastagens, desempenho animal, lotação e produtividade}

Os animais utilizados no experimento foram machos da raça nelore, com cerca de 10 meses de idade. Eles foram castrados com burdizo dois meses antes do início do período de observação. Para cada tratamento foram selecionados quatro testers principais e quatro secundários (reserva) para avaliar o desempenho animal.

A seleção dos animais testers foi feita com base no PV. Os animais foram listados em ordem decrescente de peso e depois formado grupos com três animais. Os três primeiros animais mais pesados (primeiro grupo) foram sorteados entre os tratamentos. Em seguida foi sorteado os três animais do segundo grupo mais pesados e assim sucessivamente até completar os 24 testers. Um dos testers primários teve que ser substituído pois o seu comportamento era mais agressivo que o restante do grupo. A Tabela 4 contém o PV dos testers no início do período de experimental.

A pesagem dos animais era feita as 8 horas da manhã com intervalos de 18 dias. Essas pesagens foram utilizadas para calcular a carga animal nos piquetes. A estimativa do GPV era feita a cada 36 dias, ou seja, a cada vez que se completava um ciclo. Os animais foram mantidos em jejum (água e alimento) por cerca de 15 horas antes das pesagens. 
Tabela 4. Peso vivo em $\mathrm{kg}$ dos animais testers primários no primeiro dia (30/10/1999) do período experimental.

\begin{tabular}{cccc}
\hline $\begin{array}{c}\text { Testers primários por grupos } \\
\text { de PV inicial }\end{array}$ & \multicolumn{3}{c}{ Tratamentos } \\
\cline { 1 - 1 } & \multicolumn{3}{c}{ Kg/cab. de PV em jejum } \\
1 & 241 & 245 & 242 \\
2 & 218 & 239 & 237 \\
3 & 204 & 236 & 233 \\
4 & 192 & 235 & 208 \\
& & & \\
Média & 214 & 238 & 230 \\
\hline
\end{tabular}

A quantidade de testers foi determinada em função da projeção da produção de forragem para o período de "inverno", de forma que, os testers primários não precisariam sair da área experimental em nenhum momento do período experimental. Entretanto, não foi possível realizar o pastejo no ciclo nove pois a produção da pastagem nesse ciclo foi menor do que a projetada e dessa forma seria impossível manter os $1000 \mathrm{~kg} / \mathrm{ha}$ de matéria seca verde no resíduo do $\mathrm{T} 1$ sem diminuir a quantidade de tersters. Durante esse ciclo os testers permaneceram nos pastos de apoio localizados ao redor da área experimental e foram suplementados com volumoso e concentrado. Faltando cerca de dez dias para iniciar o ciclo dez, foi criada uma nova área de apoio e os testers foram mantidos, exclusivamente a pasto, nessa área até o início do ciclo dez.

Antes dos animais entrarem nos piquetes era feita uma avaliação visual da massa de forragem em $\mathrm{kg} \mathrm{MS} /$ ha por cerca de 3 a 5 pessoas. Em função dessa avaliação e das estimativas da porcentagem de material verde na planta, porcentagem de perdas e do consumo diário de matéria seca verde (2,0 a 2,3\% 
do PV) era calculado o número de animais (eq. 2) necessários para consumir, em 3 dias, a forragem nos piquetes e manter a massa de forragem no resíduo correspondentes aos tratamentos.

$$
N A=\left(\left(M F P{ }^{*} P M V * 100^{-1}(100-P P)^{*} 100^{-1}\right)-M F R\right)^{*} \mathrm{PO}^{-1 *} \mathrm{C}^{-1 *} \mathrm{TP}
$$

Onde:

$$
\begin{aligned}
& \mathrm{NA}=\text { número de animais por piquete; } \\
& \mathrm{MFP} \text { = massa de forragem pré pastejo ( } \mathrm{kg} / \mathrm{ha} \text { de } \mathrm{MS}) ; \\
& \mathrm{PMV} \text { = porcentagem de material verde na planta; } \\
& \mathrm{PP}=\text { porcentagem de perdas pela ação do pastejo; } \\
& \mathrm{MFR} \text { = massa de forragem no resíduo ( } \mathrm{kg} / \mathrm{ha} \text { de } \mathrm{MS} \text { verde); } \\
& \mathrm{PO}=\text { período de ocupação do piquete (três dias); } \\
& \mathrm{C}=\text { consumo ( } \mathrm{kg} \text { de MS verde/cabeça/dia); } \\
& \mathrm{TP}=\text { tamanho dos piquetes }(0,1333 \mathrm{ha}) .
\end{aligned}
$$

Para auxiliar na estimativa das perdas e porcentagem de material verde na planta era levado em consideração os valores determinados nos ciclos anteriores de pastejo.

No final de cada dia era feita a avaliação visual da massa de forragem nos piquetes para ajustar a quantidade de animais nos piquetes.

A produtividade de cada bloco por ciclo de pastejo foi calculada através da quantidade média de cabeças (ajustado em função do peso médio dos testers) que ocuparam o piquete B multiplicada pelo GPV médio dos testers do ciclo correspondente. 


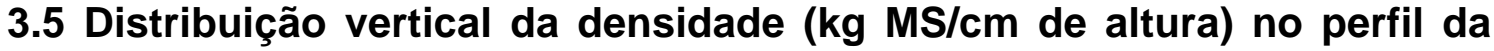 touceira}

As amostras destinadas àavaliação da distribuição vertical da massa de forragem no perfil da touceira ou do dossel foram amarradas de forma que as folhas ficaram todas esticadas e eretas (Figura 10) e depois empacotadas em sacos plásticos pretos. Depois os pacotes eram identificados e armazenados no freezer.

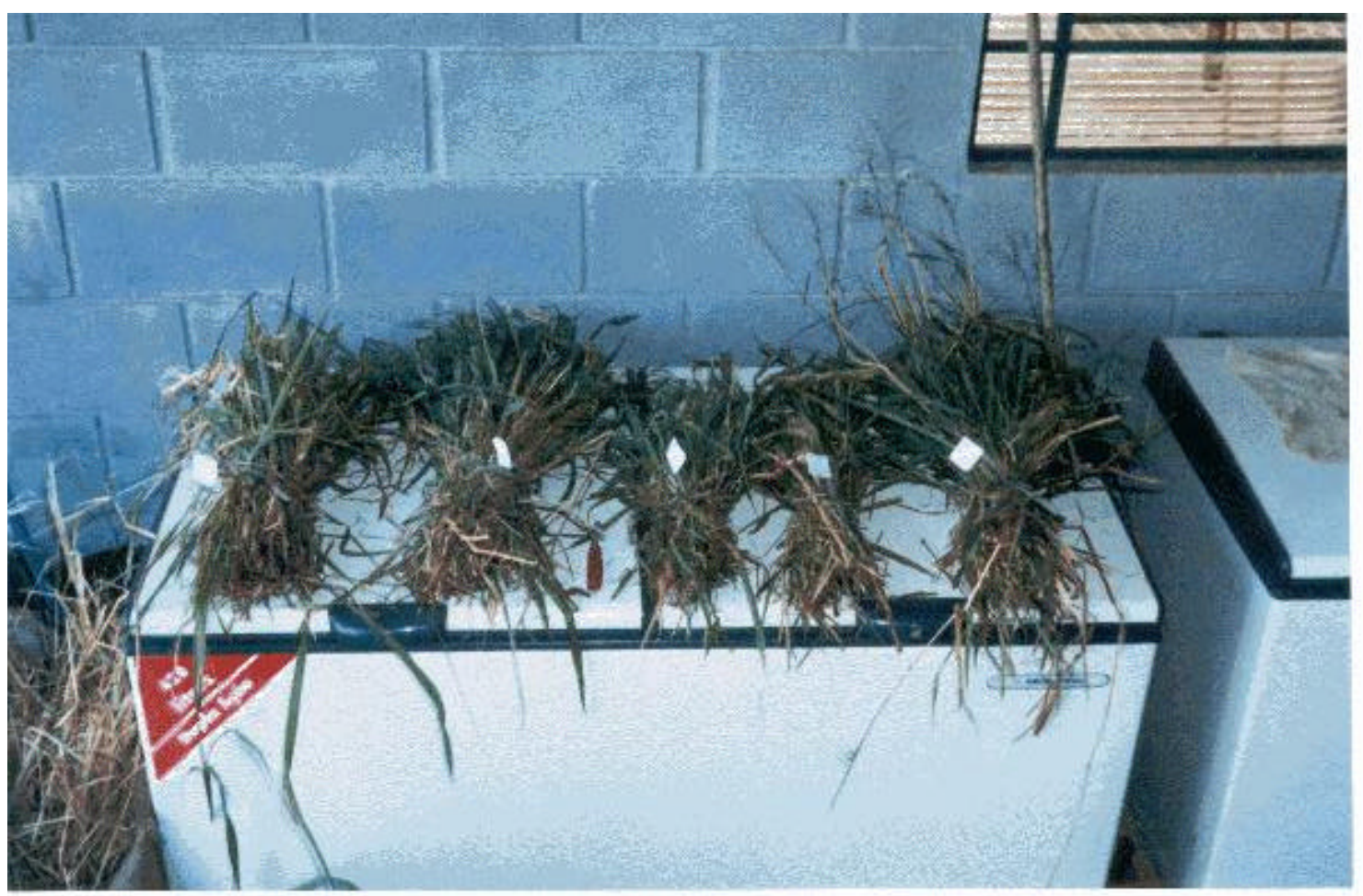

Figura 10 - Fotografia das amostras preparadas para serem empacotadas e congeladas para depois serem utilizadas para avaliação da distribuição vertical da massa de forragem no perfil da touceira ou do dossel.

Antes de iniciar o processamento as amostras eram descongeladas por cerca de duas horas em temperatura ambiente e dispostas em bancadas de serviço na posição horizontal quando se realizava as medições da altura total 
da amostra ou seja o comprimento entre a base (corte) até o ápice da amostra (ponta da inflorescência ou de uma folha). Depois era definido o local na amostra que correspondia a altura efetiva da planta no campo. Essa definição era necessária uma vez que, a altura total da amostra era superior àaltura das plantas medida efetivamente no campo uma vez que, os perfilhos mais externos das touceiras e suas folhas estavam inclinados por ocasião da colheita (Figura 11). Desse modo, se os perfilhos nas touceiras, por ocasião da colheita, fossem posicionados de forma ereta e suas folhas esticadas para o alto, as touceiras passariam a ter formato semelhante ao da amostra colocada sobre a mesa (Figura 10 e 12).

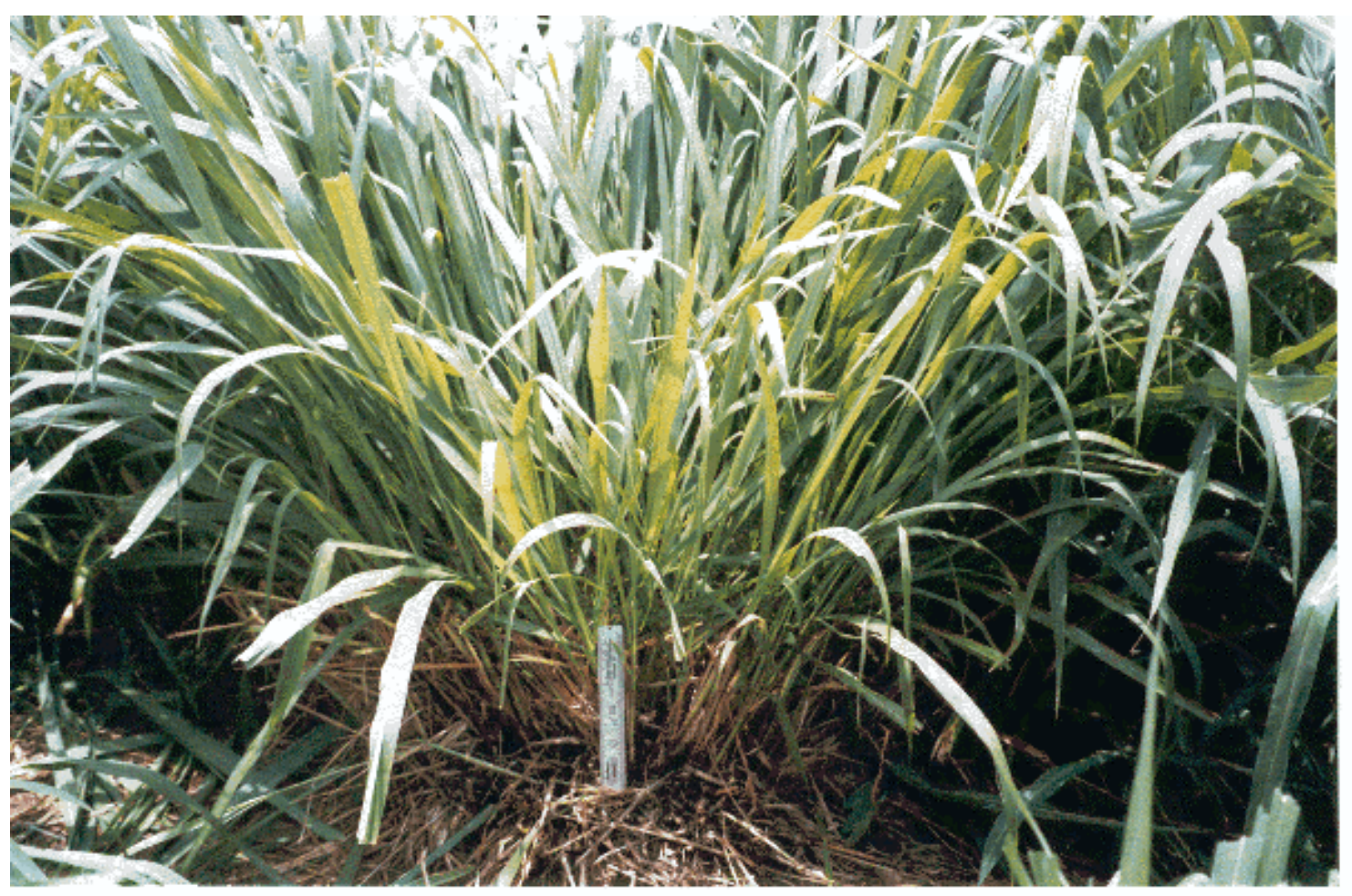

Figura 11 - Imagem do perfil de um touceira de capim Tanzânia cortada vertical no meio da sua área basal lembrando o formato de um cone invertido. 
Altura total

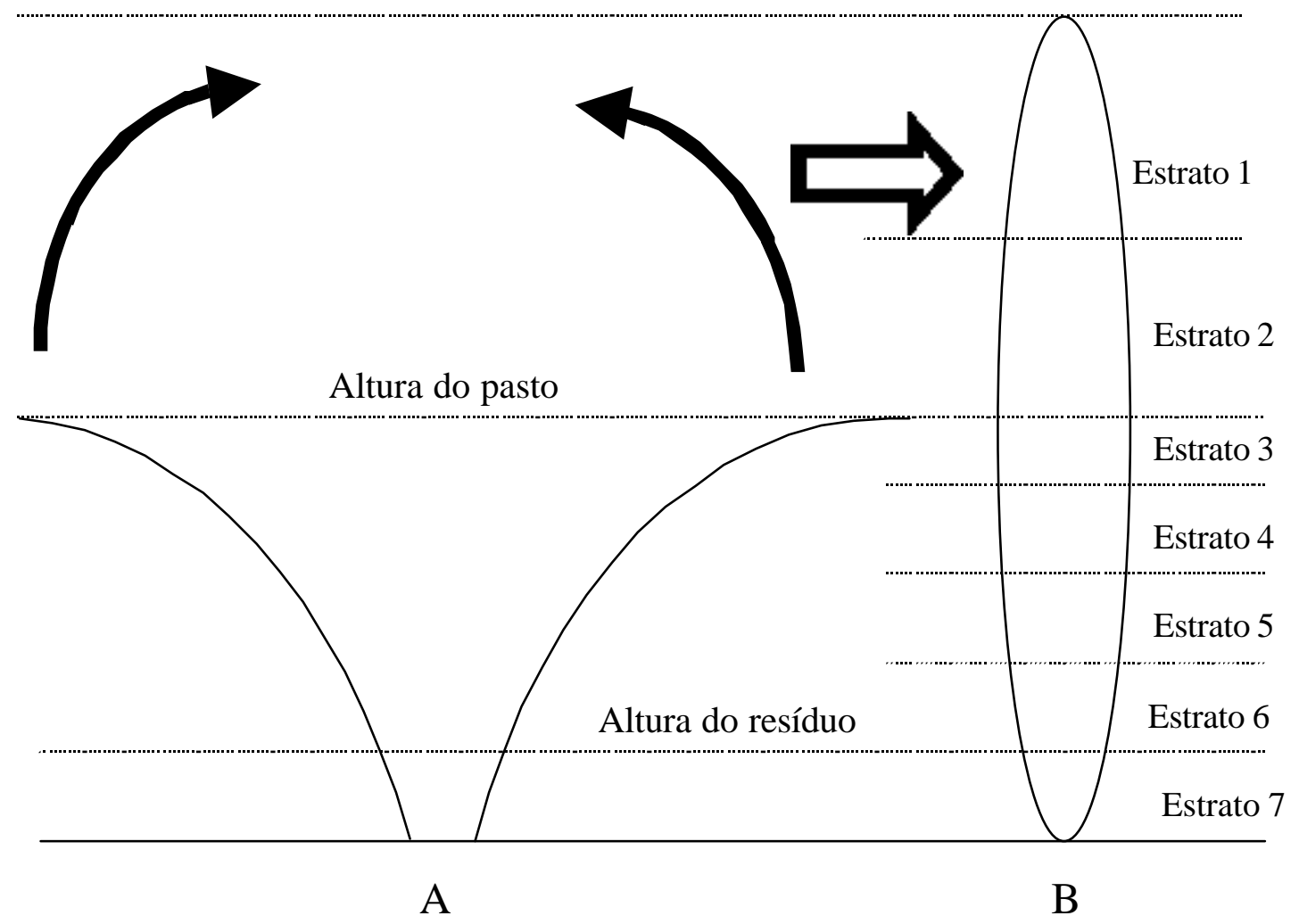

Figura 12 - Croqui comparando os formatos da touceira ou das plantas por ocasião do corte $(A)$ e posicionando os perfilhos e suas folhas de forma ereta e esticados para cima (B). Esta sendo indicado como os estratos forma separados.

Para definir a altura na amostra que corresponderia a altura efetiva das plantas na touceira foi necessário realizar um treinamento de campo antes de iniciar o processamento das amostras. O treinamento foi realizado no campo e visava identificar nas plantas posicionadas de forma ereta e com sua folhas esticadas para o alto, a altura da touceira antes do seu formato ser alterado (Figura 12). 
O próximo passo foi definir na amostra o local que corresponderia à altura do resíduo pós pastejo. Para essa determinação foi necessário conduzir outro pré experimento (4) que teve como objetivo avaliar o efeito da altura das touceiras (plantas) sobre a profundidade de pastejo na touceira.

Esse pré - experimento começou a partir do quarto ciclo e foi conduzido nos piquetes $A$ dos tratamentos $\mathrm{T} 1$ e T3. Antes dos animais entrarem nos piquetes, nove touceiras, próximas uma das outras, eram selecionadas ( 3 altas, 3 médias e 3 baixas) e marcadas com uma estaca próxima àbase da touceira. A altura da touceira foi medida, conforme mencionado no item 3.2, junto à estaca pois o animais, as vezes, consumiam a touceira de forma irregular.

No inicio dessas avaliações, a medida da altura era realizada somente antes e após o período de ocupação dos piquetes. Depois do oitavo ciclo a altura da touceira passou a ser medida em todos os dias do período de ocupação dos piquetes. Pelos resultados observa-se que houve uma relação linear entre a altura no pré e pós pastejo, independente do tratamento e do dia de pastejo. Com esse resultado foi possível determinar o local na amostra que representaria a altura do pasto após o pastejo através da seguinte eq. (3).

$A R A=A T A^{*}\left(A R P^{*} A P P^{-1}\right)$

Onde:

ARA = Altura do resíduo na amostra;

ATA = Altura da amostra equivalente a altura da touceira antes do pastejo;

$A R P=$ Altura do pasto após o pastejo (média de 30 pontos) no piquete em que foi coletada a amostra;

APP $=$ Altura do pasto antes do pastejo (média de 30 pontos) no piquete em que foi coletada a amostra. 
O processamento consistiu em separar a amostra em estratos. A porção compreendida entre a altura total e o ponto equivalente à altura da touceira antes do pastejo foi dividido em dois estratos de comprimentos iguais (estratos 1 e 2 - Figura 12). A porção compreendida entre os pontos referentes a altura da touceira antes e após o pastejo foi separada em quatro extratos iguais ou seja $25 \%$ para cada um (estratos 3, 4, 5 e 6 ). O material vegetal de cada estrato foi pesado e levado para a estufa $\left(55^{\circ} \mathrm{C}\right.$ por no mínimo 96 horas) para determinar o teor e a quantidade de matéria seca de cada estrato.

\subsection{Taxa de ocupação e tamanho da área basal das touceiras, angulo de inclinação e disposição dos perfilhos mais externos da touceira}

A taxa de ocupação (TO) foi definida pela porcentagem do solo ocupado pela área basal das touceiras e foram determinadas nos piquetes $B$ logo após a saída dos animais. Entretanto, em alguns casos, a vegetação após o pastejo nos piquetes dos T2 e T3 dificultava a identificação da base das touceiras. Para diminuir os possíveis erros de amostragens gerados por essa situação ficou definido que seria considerado como base da touceira uma área de $10 \mathrm{~cm}$ maior que o raio da touceira. As amostragens foram realizadas com o auxilio de uma linha transecta de $30 \mathrm{~m}$ de comprimento que era posicionada transversalmente no piquete a cerca de 50 a $100 \mathrm{~cm}$ de altura. A cada $20 \mathrm{~cm}$ da linha era determinada a presença ou não da base da touceira com o auxilio de um haste de ferro que deslizava perpendicularmente à marca na linha até atingir o solo ou a base da touceira.

O tamanho das touceiras (TT) foi estimado através do número de pontos que incidiram consecutivamente sobre a mesma touceira. Assim as touceiras denominadas de um ponto significa que somente um ponto incidiu sobre ela indicando ser uma planta de menor diâmetro comparada com as touceiras que 
tiveram 2 ou mais pontos. A participação de determinado tamanho de touceira foi estimado através de porcentagem em função do número total de touceiras.

A touceira do capim Tanzânia tinha o formato de uma cone invertido (Figura 13). Para medir o angulo da inclinação do cone, ou seja dos perfilhos mais externos da touceira, em relação ao solo foi utilizado quatro touceiras por tratamento (T1 e T3). As touceiras foram cortadas verticalmente no meio da base da touceira formando um painel e depois eram fotografadas. As fotos foram escaneadas e através do programa Paintbrush era desenhada uma linha paralela aos perfilhos mais externos da touceira (Figura 14 e Figura 15) e depois identificada às coordenadas das extremidades dessa linha. Desse modo foi possível calcular o angulo da inclinação da touceira com auxilio de funções de trigonometria. Esse procedimento foi realizado nas fotos das touceiras antes do pastejo e após o primeiro dia de pastejo pois a porção superior das folhas formavam uma curva e desse modo poderia afetar a avaliação do ângulo da touceira em relação ao solo .

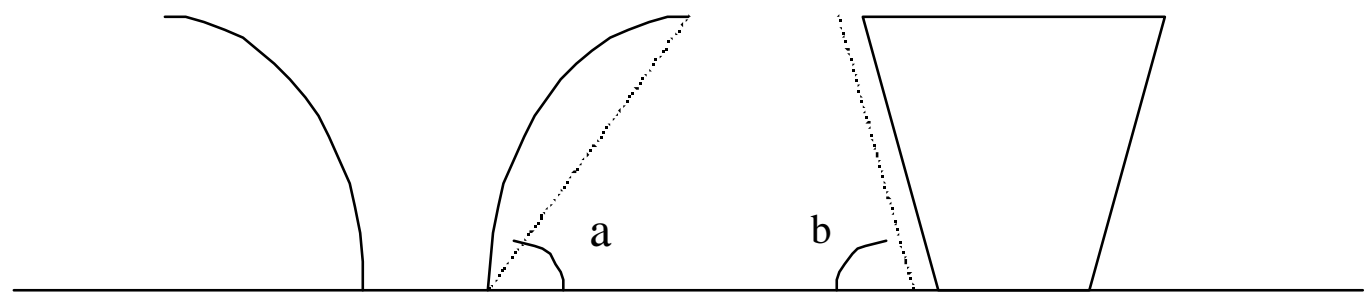

A

B

Figura 13 - Croqui indicando o formato ( $\mathrm{A}$ e B) e o angulo ( $\mathrm{a}$ e b) da touceira antes e após o primeiro dia de pastejo, respectivamente.

Usando o mesmo recurso foi possível criar uma sequência de pontos na foto da touceira que representasse a disposição dos perfilhos mais externos do perfil da touceira (Figura 14). Com as coordenadas desses pontos foi possível gerar uma linha de tendência e equações de modo que elas representassem à disposição das folhas no perfil da touceira em relação à base da touceira no 
eixo $\mathrm{X}$ e ao solo no eixo $\mathrm{Y}$. As unidades da altura e distância foram expressas em porcentagem afim de ajustar para um mesmo tamanho os perfis das touceiras pois a as touceiras fotografadas tinham tamanhos diferentes e dessa forma não é possível agrupar as coordenadas na mesma equação. Ficou definido que as coordenadas do ponto mais próximo à base da touceira corresponderiam a altura relativa ao solo e distância relativa a base da touceira igual a $0 \%$ enquanto que, as coordenadas do ponto mais extremo da base da touceira corresponde a 100\% (Figura 14).

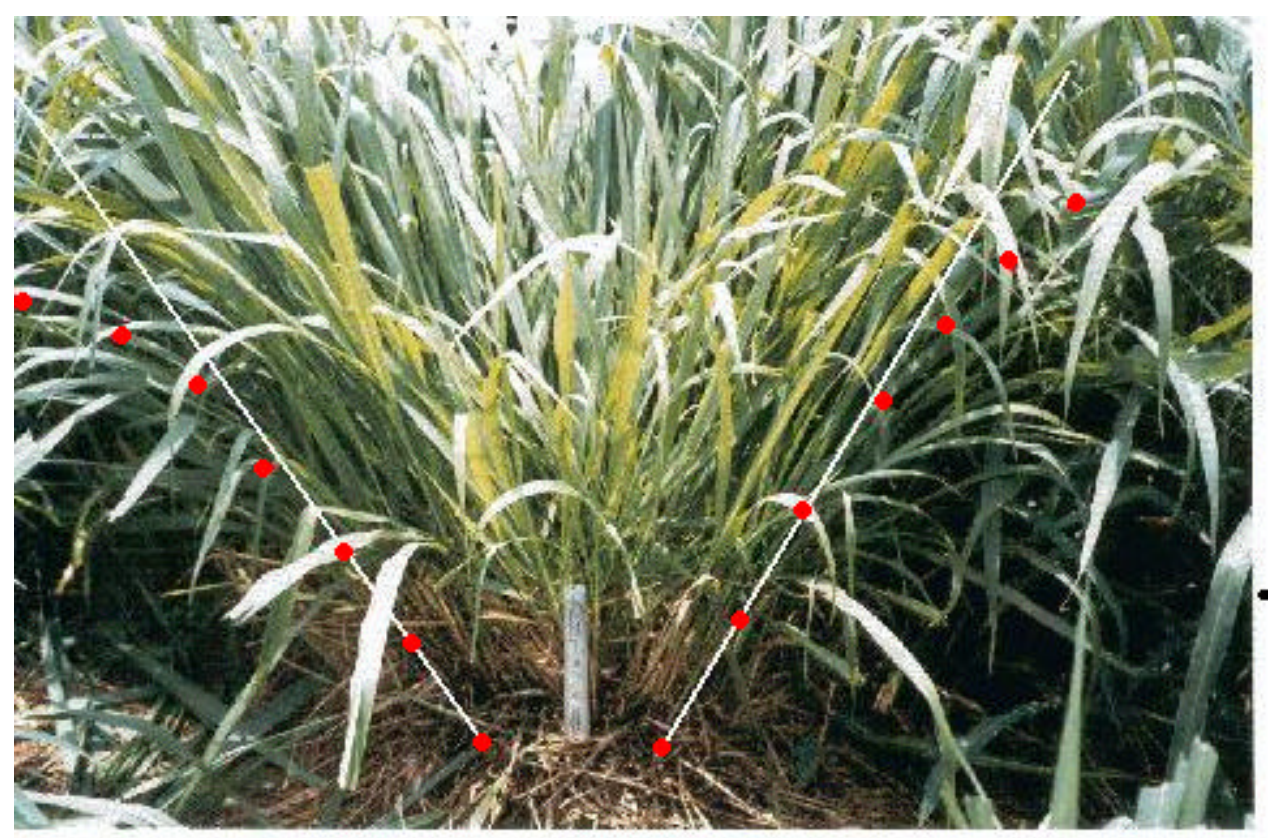

Figura 14 - Imagem do perfil de um touceira de capim Tanzânia (antes do pastejo) cortada vertical no meio da sua área basal e marcada com uma linha branca indicando a inclinação por perfilhos mais externos da touceira. A sequência de pontos vermelhos representam o formato externo da touceira. 


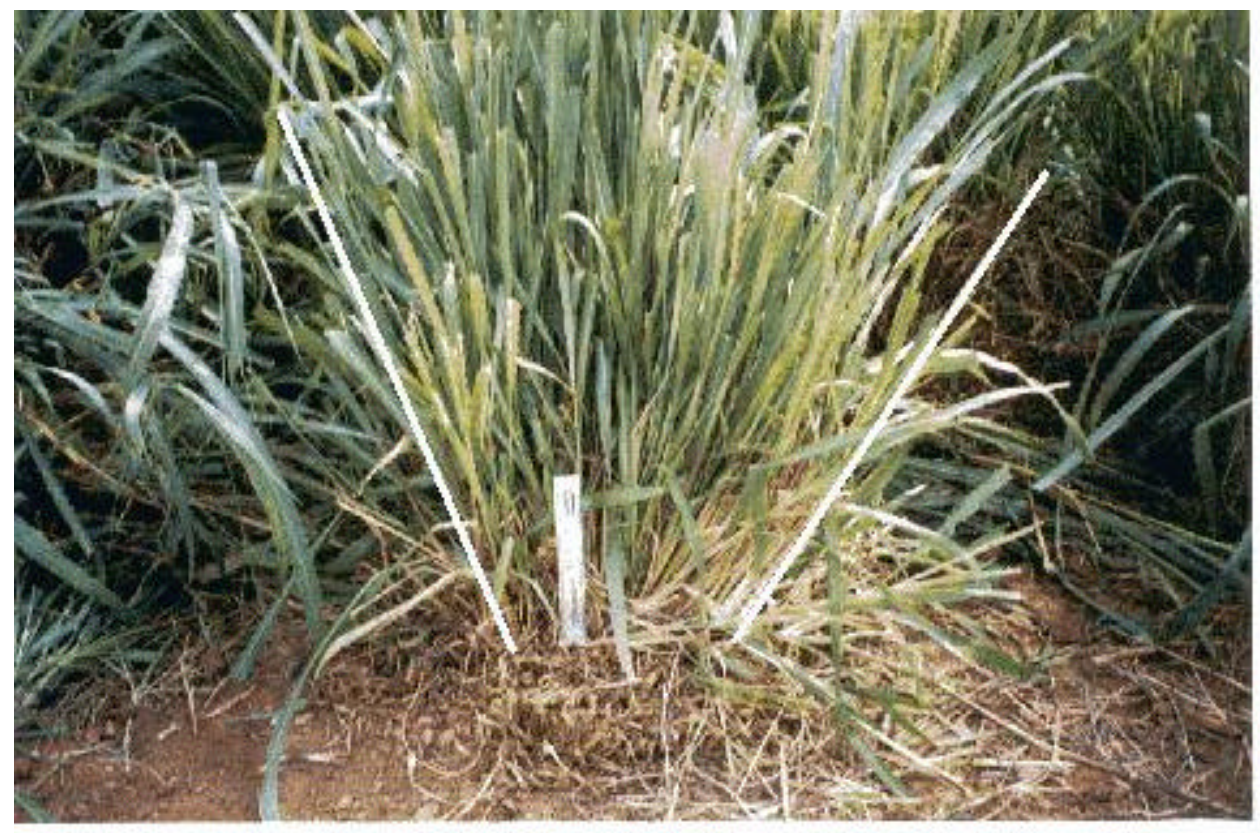

Figura 15 - Imagem do perfil de um touceira de capim Tanzânia (após o primeiro dia de pastejo) cortada verticalmente no meio da sua área basal lembrando o formato de um cone invertido.

\subsection{Análise estatística}

A análise de dados com medidas repetidas envolve a especificação de um modelo para os valores médios em cada uma das ocasiões e para a estrutura de covariâncias entre as medidas feitas ao longo das ocasiões, visto que a estrutura de covariâncias tem uma influência direta sobre as estimativas da variabilidade dos parâmetros associados às médias e em alguns casos, pode afetar as próprias estimativas desses parâmetros].

Considerando que no presente estudo as medidas das variáveis, foram feitas de um modo sistemático (ao longo de onze ciclos de pastejo) em cada unidade experimental, espera-se uma correlação não nula entre essas observações e uma heterocedasticidade das variâncias, sugerindo o uso de 
uma estrutura de covariâncias complexa e com muitos parâmetros a serem estimados.

Neste contexto, ao invés dos onze ciclos de pastejo definidos inicialmente, foram definidos quatro épocas (Tabela 5), que resumem os resultados dos ciclos que as compõem e facilitam a definição de uma estrutura de covariâncias parcimoniosa. Foi realizado uma análise exploratória para verificar as pressuposições do modelo estatístico para então efetuar a análise de perfis dos dados resultantes de um delineamento em blocos completos, para estudar o comportamento dos tratamentos ao longo das épocas.

Tabela 5. Distribuição dos ciclos de pastejo nas épocas e seus respectivos períodos de ocorrência.

\begin{tabular}{ccc}
\hline Época & Ciclo & Período \\
\hline \multirow{2}{*}{1} & 1 & $30 / 10 / 99-04 / 12 / 99$ \\
& 2 & $05 / 12 / 99-09 / 01 / 00$ \\
& 3 & $10 / 01 / 00-14 / 02 / 00$ \\
& & \\
2 & 4 & $15 / 02 / 00-21 / 03 / 00$ \\
& 5 & $22 / 03 / 00-26 / 04 / 00$ \\
& 6 & $27 / 04 / 00-01 / 06 / 00$ \\
& & \\
& 7 & $02 / 06 / 00-07 / 07 / 00$ \\
& 8 & $08 / 07 / 00-12 / 08 / 00$ \\
& 10 & $18 / 09 / 00-23 / 10 / 00$ \\
& 11 & $24 / 10 / 00-28 / 11 / 00$ \\
& 12 & $29 / 11 / 00-03 / 01 / 01$ \\
\end{tabular}


Quando houve interação entre tratamentos e épocas, foram comparadas as médias de tratamentos dentro de cada época, bem como das épocas dentro de cada tratamento, usando o teste t-Student para as médias de mínimos quadrados correspondentes. O nível de significância utilizado nas comparações foi de 5\%. Para essas análises foi utilizado o PROC MIXED do SAS (1995), conforme descrito por LIMA (1996). As regressões linear e quadráticas foram analisadas através do PROC GLM do SAS (1995) e o nível de significância utilizado nas comparações foi de $5 \%$.

\subsection{Estimativas de alguns parâmetros baseados nas determinações de características de produção da planta forrageira}

Através das determinações da massa de forragem antes do pastejo, pós pastejo, perdas de forragem, altura da planta, porcentagem de folha, de haste e de material morto, da carga animal, etc., foi possível estimar e avaliar outros parâmetros. Segue abaixo a forma como foram estimados esses parâmetros.

a) Produção de forragem (MS, MSV, folhas, haste, material morto): massa de forragem (MS, MSV, folhas, haste, material morto) cortada a $5 \mathrm{~cm}$ do solo e expresso em $\mathrm{kg} / \mathrm{ha}$

b) Densidade de forragem (MS, MSV, folhas, haste, material morto): produção de forragem (MS, MSV, folhas, haste, material morto) dividida pela altura da planta;

c) Relação folha/haste : produção de folhas/produção de haste;

d) Participação de folhas (haste ou material morto) na pastagem: massa de folhas (haste ou material morto) dividida pela soma das massas de folhas, haste e material morto; 
e) Produção de folhas, haste e material morto na pastagem ou de forragem perdida: produção de forragem (MS) ou da massa de forragem perdida multiplicado pela participação de folhas, haste e material morto;

f) Produção total de forragem (MS, MSV, folhas, haste, material morto): soma das produções de forragem (MS, MSV, folhas, haste, material morto) estimadas em cada ciclo;

g) Produção acumulada de forragem (MS, MSV, folhas, haste, material morto): produção de forragem (MS, MSV, folhas, haste, material morto) antes do pastejo menos a produção de forragem (MS, MSV, folhas, haste, material morto) pós pastejo do ciclo anterior;

h) Produção total acumulada de forragem (MS, MSV, folhas, haste, material morto): soma das produções acumuladas de forragem (MS, MSV, folhas, haste, material morto) estimadas em cada ciclo;

i) Total de massa de forragem perdida: soma das massas de forragem perdida em cada ciclo;

j) Porcentagem de perdas: massa de forragem perdida (MS, MSV, folhas, haste, material morto) dividido pela produção de forragem (MS, MSV, folhas, haste, material morto);

k) Eficiência do pastejo: massa de forragem perdida dividido pela massa de forragem acumulada;

I) Oferta de forragem: massa de forragem (MS, MSV, folhas, haste, material morto) dividido pela carga animal instantânea média durante o período de ocupação.

m) Disponibilidade de forragem: massa de forragem (MS, MSV, folhas, haste, material morto) expressa em kg/ha. 


\section{RESULTADOS E DISCUSSÃO}

\subsection{Escolha do número e da relação dimensão:formato da unidade amostral para estimar a massa de forragem}

Nos pré experimentos 1 e 2 realizados para definir a metodologia para estimar a massa de forragem no experimento principal não houve interação entre os fatores dimensão:formato e número de unidades amostrais para as variáveis coeficiente de variação (CV\%) e massa média de forragem. Dessa forma a interpretação dos resultados estatísticos de cada fator foram feitos separadamente. Nas Tabelas 6 e 7 são apresentados os resultados estatísticos dos pré experimentos 1 e 2 , respectivamente.

Tomado como referência as relações com os menores CV\% (3.00R e 2.00R nas Tabelas 5 e 6 , respectivamente) observamos que a relação dimensão:formato de $1.00 \mathrm{Q}$ é a relação de menor área que não difere dos tratamentos 3.00R e $2.00 \mathrm{R}$ nos pré experimentos 1 e 2 , respectivamente.

$\mathrm{O}$ número de amostras também teve efeito sobre o $\mathrm{CV} \%$ como pode ser observado nas Tabelas 8 e 9. A expectativa era de que aumentando o número de amostras o CV\% diminuísse, entretanto, isso não ocorreu. Resultados semelhantes foram apresentados por Mclntire (1987). Nesse contexto, é importante determinar a quantidade de amostras na qual o valor do CV\% passa a variar menos, ou seja, passa a ser constante com o aumento no número de amostras. Nesse sentido, os resultados das Tabelas 8 e 9 indicam que, a partir de 3 e 4 amostras não existe diferença estatística entre os CV\% para os pré 
experimentos 1 e 2 , respectivamente.

Tabela 6. Nível descritivo (p) para comparação entre os coeficientes de variação (CV\%) médios da relação dimensão-formato no pré experimento 1 (capim Elefante).

\begin{tabular}{|c|c|c|c|c|c|c|c|c|c|c|}
\hline \multirow{2}{*}{$\begin{array}{c}\text { Relação } \\
\text { D:F }\end{array}$} & \multirow{2}{*}{$\begin{array}{c}\text { Massa* }^{\star} \\
\mathrm{Kg} \\
\mathrm{MV} / \mathrm{m}^{2}\end{array}$} & \multirow{2}{*}{ CV\% } & \multicolumn{8}{|c|}{ Relação Dimensão:Formato (D:F) } \\
\hline & & & $0.25 Q$ & $0.25 \mathrm{R}$ & $1.00 Q$ & $1.00 \mathrm{R}$ & $2.00 Q$ & $2.00 \mathrm{R}$ & $3.00 Q$ & $3.00 \mathrm{R}$ \\
\hline $0.25 Q$ & $5,0 a b$ & 108,3 & & 0.0011 & 0.0001 & 0.0001 & 0.0001 & 0.0001 & 0.0001 & 0.0001 \\
\hline $0.25 R$ & $5,4 \mathrm{a}$ & 85,9 & 0.0011 & . & 0.0001 & 0.0001 & 0.0001 & 0.0001 & 0.0001 & 0.0001 \\
\hline $1.00 Q$ & $4,5 a b c$ & 31,1 & 0.0001 & 0.0001 & . & 0.2254 & 0.3795 & 0.8038 & 0.4762 & 0.0739 \\
\hline $1.00 \mathrm{R}$ & $4,2 \mathrm{bc}$ & 39,2 & 0.0001 & 0.0001 & 0.2254 & . & 0.7369 & 0.1449 & 0.0557 & 0.0031 \\
\hline $2.00 Q$ & $4,1 \mathrm{bc}$ & 36,9 & 0.0001 & 0.0001 & 0.3795 & 0.7369 & . & 0.2603 & 0.1131 & 0.0083 \\
\hline $2.00 \mathrm{R}$ & $4,1 \mathrm{bc}$ & 29,5 & 0.0001 & 0.0001 & 0.8038 & 0.1449 & 0.2603 & . & 0.6423 & 0.1227 \\
\hline $3.00 Q$ & $3,8 \mathrm{c}$ & 26,4 & 0.0001 & 0.0001 & 0.4762 & 0.0557 & 0.1131 & 0.6423 & & 0.2783 \\
\hline $3.00 \mathrm{R}$ & $3,9 \mathrm{c}$ & 19,1 & 0.0001 & 0.0001 & 0.0739 & 0.0031 & 0.0083 & 0.1227 & 0.2783 & . \\
\hline
\end{tabular}

*Médias seguidas pela mesma letra não são diferentes $(p<0.05)$ pelo teste de Tukey.

${ }^{* \star}$ Diferença significativa $(p<0.05)$ pelo teste t.

Tabela 7. Nível descritivo (p) para comparação entre os coeficientes de variação (CV\%) médios da relação dimensão-formato no pré experimento 2 (capim Tanzânia - pré pastejo).

\begin{tabular}{cccccccccc}
\hline $\begin{array}{c}\text { Relação } \\
\text { D:F }\end{array}$ & $\begin{array}{l}\text { Massa* } \\
\text { g MS/m }\end{array}$ & CV\% & & \multicolumn{6}{c}{ Relação Dimensão:Formato (D:F) } \\
\cline { 4 - 8 } & & $0.25 \mathrm{R}$ & $1.00 \mathrm{Q}$ & $1.00 \mathrm{R}$ & $2.00 \mathrm{Q}$ & $2.00 \mathrm{R}$ \\
\hline & & & & & & & & \\
$0.25 \mathrm{Q}$ & $339 \mathrm{~b}$ & 42,1 &. & 0.9525 & 0.0001 & 0.8466 & 0.0001 & 0.0001 \\
$0.25 \mathrm{R}$ & $329 \mathrm{~b}$ & 41,9 & 0.9525 &. & 0.0001 & 0.8934 & 0.0001 & 0.0001 \\
$1.00 \mathrm{Q}$ & $393 \mathrm{a}$ & 28,0 & 0.0001 & 0.0001 &. & 0.0001 & 0.6517 & 0.7529 \\
$1.00 \mathrm{R}$ & $400 \mathrm{a}$ & 41,4 & 0.8466 & 0.8934 & 0.0001 &. & 0.0001 & 0.0001 \\
$2.00 \mathrm{Q}$ & $419 \mathrm{a}$ & 26,9 & 0.0001 & 0.0001 & 0.6517 & 0.0001 &. & 0.8913 \\
$2.00 \mathrm{R}$ & $415 \mathrm{a}$ & 26,4 & 0.0001 & 0.0001 & 0.7529 & 0.0001 & 0.8913 &. \\
& & & & & & & & \\
\hline
\end{tabular}

*Médias seguidas pela mesma letra não são diferentes $(p<0.05)$ pelo teste de Tukey.

**Diferença significativa $(p<0.05)$ pelo teste t. 
Tabela 8. Nível descritivo (p) para comparação entre os coeficientes de variação (CV\%) médios do número de amostras através do teste t no pré experimento 1 (capim Elefante).

\begin{tabular}{|c|c|c|c|c|c|c|c|c|c|}
\hline \multicolumn{3}{|c|}{ Massa* } & \multicolumn{7}{|c|}{ Números de amostras (NA)** } \\
\hline NA & $\mathrm{Kg} \mathrm{MV} / \mathrm{m}^{2}$ & CV\% & 2 & 3 & 4 & 5 & 6 & 7 & 8 \\
\hline 2 & $4,4 \mathrm{a}$ & 32,7 & & 0.0398 & 0.0270 & 0.0026 & 0.0160 & 0.0050 & 0.0007 \\
\hline 3 & $4,6 \mathrm{a}$ & 45,6 & 0.0398 & & 0.8720 & 0.3168 & 0.7141 & 0.4333 & 0.1556 \\
\hline 4 & $4,6 \mathrm{a}$ & 46,6 & 0.0270 & 0.8720 & & 0.4004 & 0.8373 & 0.5332 & 0.2073 \\
\hline 5 & $4,3 a$ & 51,8 & 0.0026 & 0.3168 & 0.4004 & & 0.5246 & 0.8270 & 0.6722 \\
\hline 6 & $4,3 \mathrm{a}$ & 47,9 & 0.0160 & 0.7141 & 0.8373 & 0.5246 & & 0.6759 & 0.2903 \\
\hline 7 & $4,3 \mathrm{a}$ & 50,5 & 0.0050 & 0.4333 & 0.5332 & 0.8270 & 0.6759 & & 0.5214 \\
\hline 8 & $4,0 \mathrm{a}$ & 54,5 & 0.0007 & 0.1556 & 0.2073 & 0.6722 & 0.2903 & 0.5214 & . \\
\hline
\end{tabular}

*Médias seguidas pela mesma letra não são diferentes $(p<0.05)$ pelo teste de Tukey.

${ }^{* *}$ Diferença significativa $(p<0.05)$ pelo teste t.

Tabela 9. Nível descritivo (p) para comparação entre os coeficientes de variação $(\mathrm{CV} \%)$ médios do número de amostras através do teste t no pré experimento 2 (capim Tanzânia - pré pastejo).

\begin{tabular}{|c|c|c|c|c|c|c|c|c|c|c|}
\hline \multirow[t]{2}{*}{ NA } & \multirow{2}{*}{$\begin{array}{l}\text { Massa* } \\
\text { g MS/m² }\end{array}$} & \multirow[b]{2}{*}{ CV\% } & \multicolumn{8}{|c|}{ Número de amostras (NA) ${ }^{\star *}$} \\
\hline & & & 2 & 3 & 4 & 5 & 6 & 7 & 8 & 9 \\
\hline 2 & $366 \mathrm{a}$ & 19,6 & & 0.0147 & 0.0002 & 0.0001 & 0.0001 & 0.0001 & 0.0001 & 0.0001 \\
\hline 3 & 399 a & 29,3 & 0.0147 & & 0.1714 & 0.1112 & 0.0714 & 0.0218 & 0.0025 & 0.0042 \\
\hline 4 & $417 \mathrm{a}$ & 34,6 & 0.0002 & 0.1714 & & 0.8198 & 0.6593 & 0.3465 & 0.0898 & 0.1276 \\
\hline 5 & $397 a$ & 35,5 & 0.0001 & 0.1112 & 0.8198 & & 0.8312 & 0.475 & 0.1412 & 0.1942 \\
\hline 6 & $384 \mathrm{a}$ & 36,3 & 0.0001 & 0.0714 & 0.6593 & 0.8312 & & 0.616 & 0.2075 & 0.2772 \\
\hline 7 & $377 \mathrm{a}$ & 38,3 & 0.0001 & 0.0218 & 0.3465 & 0.475 & 0.616 & & 0.4464 & 0.5573 \\
\hline 8 & $361 \mathrm{a}$ & 41,3 & 0.0001 & 0.0025 & 0.0898 & 0.1412 & 0.2075 & 0.4464 & & 0.8611 \\
\hline 9 & $359 a$ & 40,6 & 0.0001 & 0.0042 & 0.1276 & 0.1942 & 0.2772 & 0.5573 & 0.8611 & \\
\hline
\end{tabular}

*Médias seguidas pela mesma letra não são diferentes $(p<0.05)$ pelo teste de Tukey.

${ }^{* \star}$ Diferença significativa $(p<0.05)$ pelo teste $t$. 
Os pesquisadores Guzman et al. (1992) também utilizaram o critério da estabilização do CV\% para determinarem o melhor tamanho e formato da unidade amostral para estimar a massa de forragem em pastagens de capim Elefante estabelecidas em relevos planos e inclinados. Os pesquisadores utilizaram os métodos da máxima curvatura do coeficiente de variação (MCCV) e máxima curvatura do coeficiente de variação modificado (MCCVM). Os autores concluíram que pelo método da MCCV, o tamanho ideal da unidade amostral esta entre 1,0 a $1,75 \mathrm{~m}^{2}$ no relevo plano e de 1,25 a 1,75 $\mathrm{m}^{2}$ no relevo inclinado. Pelo método MCCVM o tamanho seria de $1,0 \mathrm{~m}^{2}$ e 1,5 $\mathrm{m}^{2}$ para os relevos planos e inclinados, respectivamente. Os autores também indicaram que o formato retangular seria mais indicados pois os $\mathrm{CV} \%$ foram mais baixos do que no formato quadrado. Entretanto, no trabalho não há informações sobre análise estatística dessa comparação. Nesse caso, é possível levantar a hipótese de que os CV\% observados nos formatos retangulares e quadrados seriam estatisticamente iguais pois os valores dos $\mathrm{CV} \%$ foram semelhantes entre os formatos $(20,5 ; 17,8$; e $20,1 \%$ para os formatos $0,5 \times 2,0 \mathrm{~m} ; 2,0 \times 0,5 \mathrm{~m}$ e $1,0 \times 1,0 \mathrm{~m}$ no relevo plano, respectivamente e de 18,$1 ; 11,2 ; 17,6$ e17,2\% para os formatos $0,5 \times 3,0 \mathrm{~m} ; 3,0 \times 0,5 \mathrm{~m} ; 1,0 \times 1,5 \mathrm{~m} \mathrm{e} 1,5 \times 1,0 \mathrm{~m}$ no relevo inclinado, respectivamente).

Por sua vez, no pré experimento 3 (capim Tanzânia - pós pastejo) houve interação entre os fatores número de amostras e a relação dimensão:formato. Neste caso todas as 48 interações deveriam ser comparadas entre si. Entretanto a análise comparativa dos resultados é difícil de ser realizar devido a quantidade de interações. Nesse caso a análise exploratória dos dados mostrou que as observações referentes a 2 amostras eram obscuras e influentes e por esse motivo estavam tornado a interação significativa. Analisando a Figura 16 verificamos os valores observados no tratamento referente a 2 amostras tem uma variação bem mais alta que as demais. Desse modo foi realizado a análise estatística desconsiderando o tratamento com 2 amostras. O resultado dessa nova análise não detectou interação entre os 
fatores e dessa forma foi possível avaliar o efeito dos fatores número de amostras e relação dimensão:formato de forma independente como nos outros trabalhos.

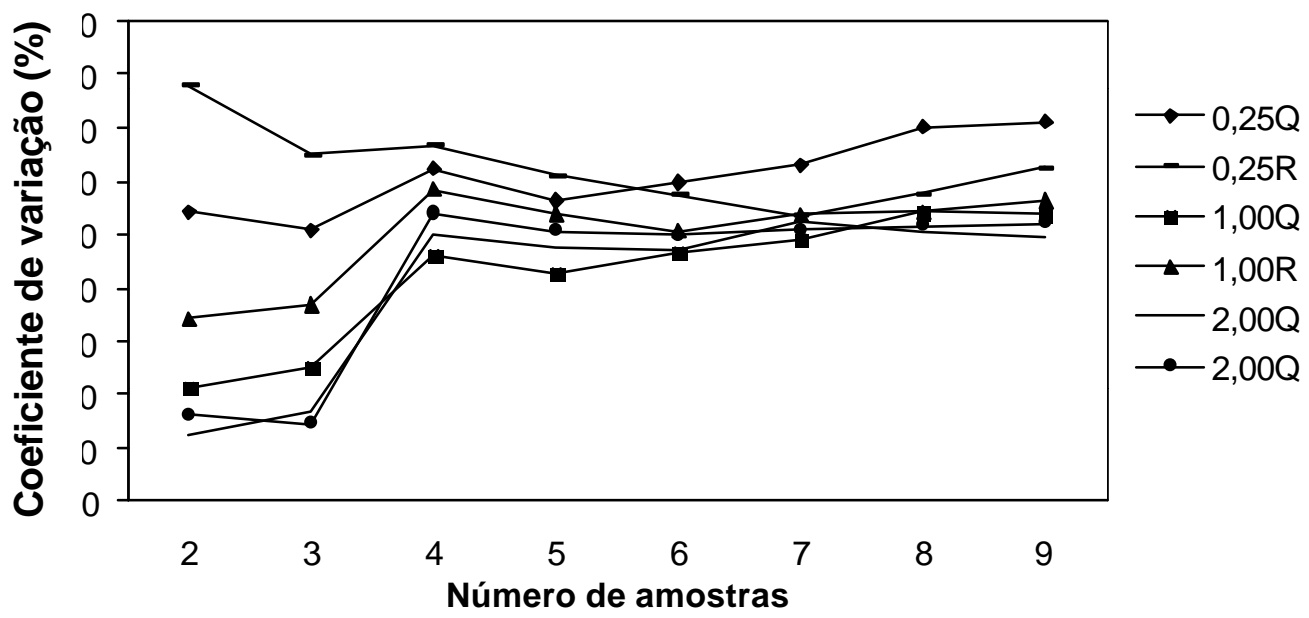

Figura 16 - Coeficiente de variação em função do número de amostras em cada relação dimensão:formato.

Nas Tabelas 10 e 11 estão os níveis descritivos (p) da análise estatística dos resultados do pré experimento 3 desconsiderando o tratamento de 2 amostras. Pelos resultados apresentados na Tabela 10 pode-se verificar que as relações com $1 \mathrm{~m}^{2}$ de área não diferem da relação com o menor CV\% (2.00R) enquanto que, pela Tabela 11, observa-se que a partir de 4 amostras não ocorre diferenças no CV\% quando o número de amostras é aumentado.

Essa conclusão esta coerente com a Figura 17 onde estão apresentados os CV\% de cada uma das 48 combinação dos fatores numero de amostras (8) e relação dimensão:formato (6). As combinações com as maiores quantidades de interações iguais $(p<0.05)$ são 4 amostras de $1 \mathrm{~m}^{2}$ no formato quadrado $(4 \mathrm{x}$ 1Q) e 5 amostras de $1 \mathrm{~m}^{2}$ no formato quadrado ( $\left.5 \times 1 Q\right)$. Também podemos observar na Figura 17 que a partir de $4 \times 1 \mathrm{Q}$ houve uma tendência de estabilizar o CV\%. 
Tabela 10. Nível descritivo (p) para comparação entre os coeficientes de variação (CV\%) médios da relação dimensão-formato no pré experimento 3 (capim Tanzânia - pós pastejo).

\begin{tabular}{ccccccccc}
\hline & \multicolumn{6}{c}{ Massa $^{*}$} & & \multicolumn{6}{c}{ Relação Dimensão:Formato (D:F) } \\
\cline { 3 - 8 } D:F & g MS/m & CV\% & $0.25 \mathrm{Q}$ & $0.25 \mathrm{R}$ & $1.00 \mathrm{Q}$ & $1.00 \mathrm{R}$ & $2.00 \mathrm{Q}$ & $2.00 \mathrm{R}$ \\
\hline & & & & & & & & \\
$0.25 \mathrm{Q}$ & $154 \mathrm{~b}$ & 62,0 &. & 0.6960 & 0.0001 & 0.0063 & 0.0001 & 0.0001 \\
$0.25 \mathrm{R}$ & $173 \mathrm{a}$ & 60,6 & 0.6960 &. & 0.0001 & 0.0186 & 0.0001 & 0.0001 \\
$1.00 \mathrm{Q}$ & $178 \mathrm{a}$ & 45,4 & 0.0001 & 0.0001 &. & 0.0712 & 0.8734 & 0.8341 \\
$1.00 \mathrm{R}$ & $170 \mathrm{ab}$ & 52,0 & 0.0063 & 0.0186 & 0.0712 &. & 0.0500 & 0.1099 \\
$2.00 \mathrm{Q}$ & $182 \mathrm{a}$ & 44,9 & 0.0001 & 0.0001 & 0.8734 & 0.0500 &. & 0.7124 \\
$2.00 \mathrm{R}$ & $184 \mathrm{a}$ & 46,2 & 0.0001 & 0.0001 & 0.8341 & 0.1099 & 0.7124 &.
\end{tabular}

${ }^{*}$ Médias seguidas pela mesma letra não são diferentes $(p<0.05)$ pelo teste de Tukey.

**Diferença significativa $(p<0.05)$ pelo teste t.

Tabela 11. Nível descritivo (p) para comparação entre os coeficientes de variação (CV\%) médios do número de amostras através do teste $\mathrm{t}$ no pré experimento 3 (capim Tanzânia - pós pastejo).

\begin{tabular}{|c|c|c|c|c|c|c|c|c|c|}
\hline \multicolumn{3}{|c|}{ Massa* } & \multicolumn{7}{|c|}{ Número de amostras (NA) ${ }^{\star \star}$} \\
\hline NA & $\mathrm{g} \mathrm{MS} / \mathrm{m}^{2}$ & CV\% & 3 & 4 & 5 & 6 & 7 & 8 & 9 \\
\hline 3 & $116 \mathrm{e}$ & 34,9 & 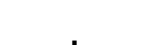 & 0.0001 & 0.0001 & 0.0001 & 0.0001 & 0.0001 & 0.0001 \\
\hline 4 & $144 d$ & 56,3 & 0.0001 & & 0.2783 & 0.2536 & 0.5092 & 0.9798 & 0.7457 \\
\hline 5 & $156 \mathrm{~cd}$ & 52,1 & 0.0001 & 0.2783 & & 0.9539 & 0.6701 & 0.2673 & 0.1599 \\
\hline 6 & $174 \mathrm{c}$ & 51,9 & 0.0001 & 0.2536 & 0.9539 & & 0.6285 & 0.2433 & 0.1436 \\
\hline 7 & $194 \mathrm{~b}$ & 53,7 & 0.0001 & 0.5092 & 0.6701 & 0.6285 & & 0.4932 & 0.3256 \\
\hline 8 & $208 a b$ & 56,4 & 0.0001 & 0.9798 & 0.2673 & 0.2433 & 0.4932 & & 0.7649 \\
\hline 9 & $223 \mathrm{a}$ & 57,6 & 0.0001 & 0.7457 & 0.1599 & 0.1436 & 0.3256 & 0.7649 & \\
\hline
\end{tabular}

*Médias seguidas pela mesma letra não são diferentes $(p<0.05)$ pelo teste de Tukey.

${ }^{* \star}$ Diferença significativa $(p<0.05)$ pelo teste $t$. 


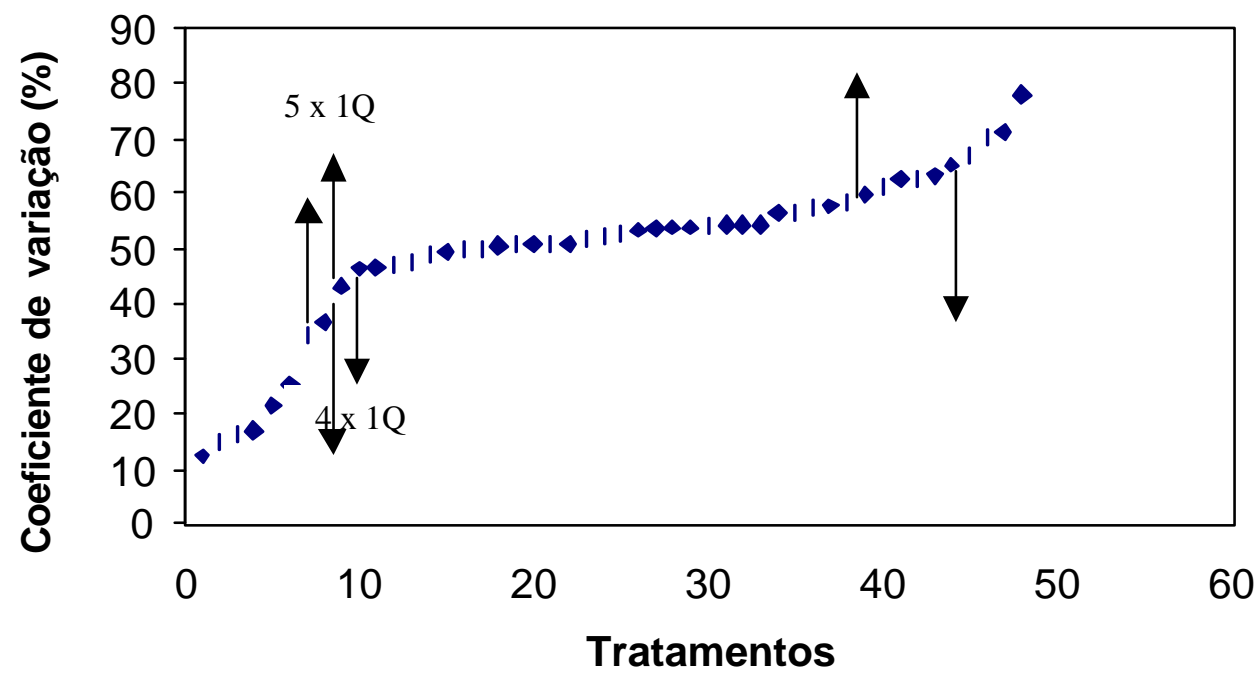

Figura 17 - Coeficientes de variação médios das 48 interações entre os fatores número de amostras e relação dimensão:formato no pré experimento 3 (capim Tanzânia - pós pastejo). A sigla $4 \times 1 Q$ significa 4 amostras, ou unidades amostrais, de $1 \mathrm{~m}^{2}$ no formato quadrado. As setas no mesmo sentido superior e inferior representam as interações que são iguais as combinações $5 \times 1 Q$ e $4 \times 1 \mathrm{Q}$, respectivamente.

Os melhores resultados observados com as moldura em formato quadrado em relação ao retangular pode estar associado a um possível fonte de erro que ocorre na colheita da forragem no perímetro da parcela pois a moldura dificulta a operação de corte (Mannetje, 1987). Além disso, pode promover dúvidas quanto a localização da planta, ou seja, se ela faz parte da parcela ou não. Dessa forma pode ocorrer corte de plantas (ou parte delas) que estão fora da parcela ou deixar no campo plantas que deveriam ser colhidas. Esse tipo de erro é menor no formato quadrado do que no retangular pois a relação perímetro:área é menor no quadrado e diminui com o aumento da área 
$(400,460,400,462,282$ e $327 \mathrm{~cm} / \mathrm{m} 2$ para $0.25 \mathrm{Q}, 0.25 \mathrm{R}, 1.00 \mathrm{Q}, 1.00 \mathrm{R}, 2.00 \mathrm{Q}$ e 2.00R, respectivamente).

Pelos resultados apresentados podemos concluir que a avaliação da massa de forragem de capins de hábito de crescimento cespitoso (que formam touceiras) deve ser feita com 4 amostras por piquete utilizando molduras de 1 $\mathrm{m}^{2}$ em formato quadrado $(1 \mathrm{~m} \times 1 \mathrm{~m})$. Através dessas dimensões obtem-se o menor coeficiente de variação com a maior eficiência no processo de amostragem.

\subsection{Efeito da altura da pastagem sobre a profundidade de pastejo.}

O efeito da altura da planta antes do pastejo foi avaliada com o objetivo de se determinar, após cada dia de ocupação do piquete a altura do resíduo através do qual pode-se determinar a profundidade do pastejo. As Figuras $18 \mathrm{e}$ 19 indicam os resultados dessa avaliações.

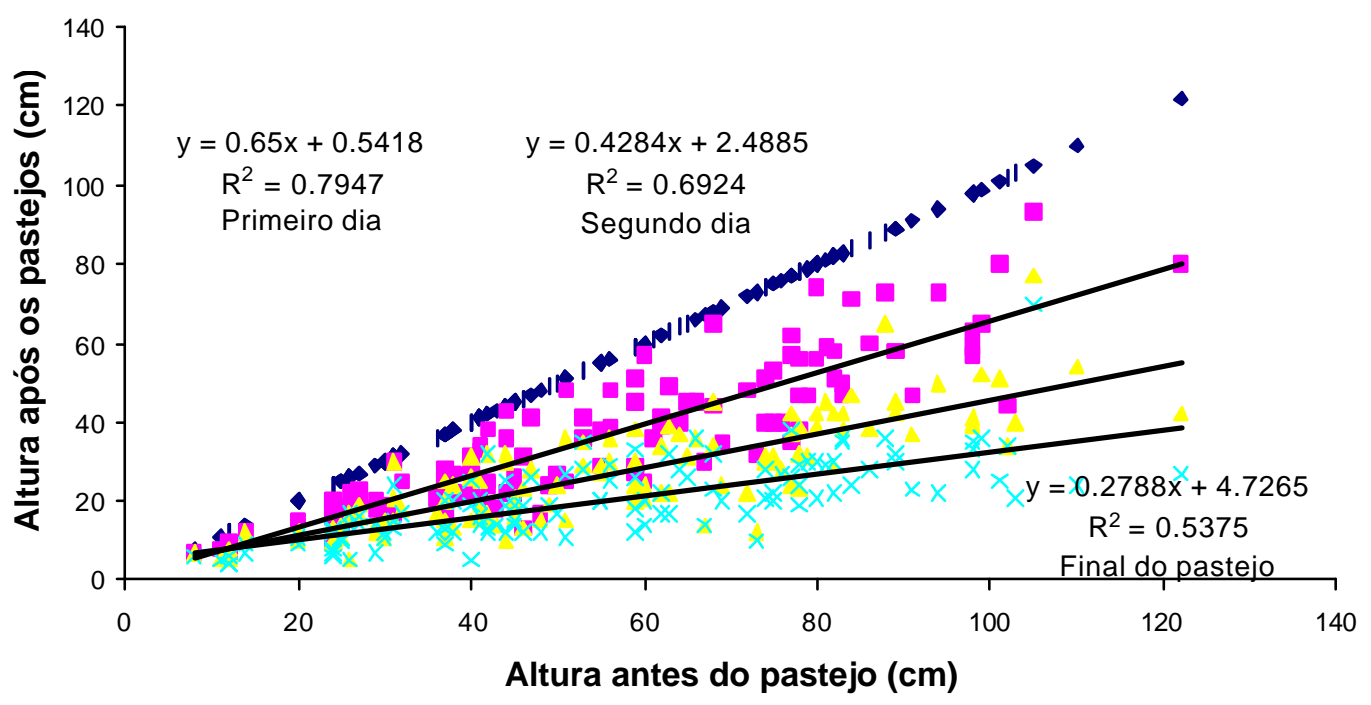

I Antes do pastejo $\quad$ Primeiro dia de pastejo $\triangle$ Segundo dia de pastejo $\times$ Final dos pastejo

Figura 18 - Relação entre a altura da planta antes do pastejo e a altura da planta após cada dia de pastejo nos piquetes do tratamento 1. 


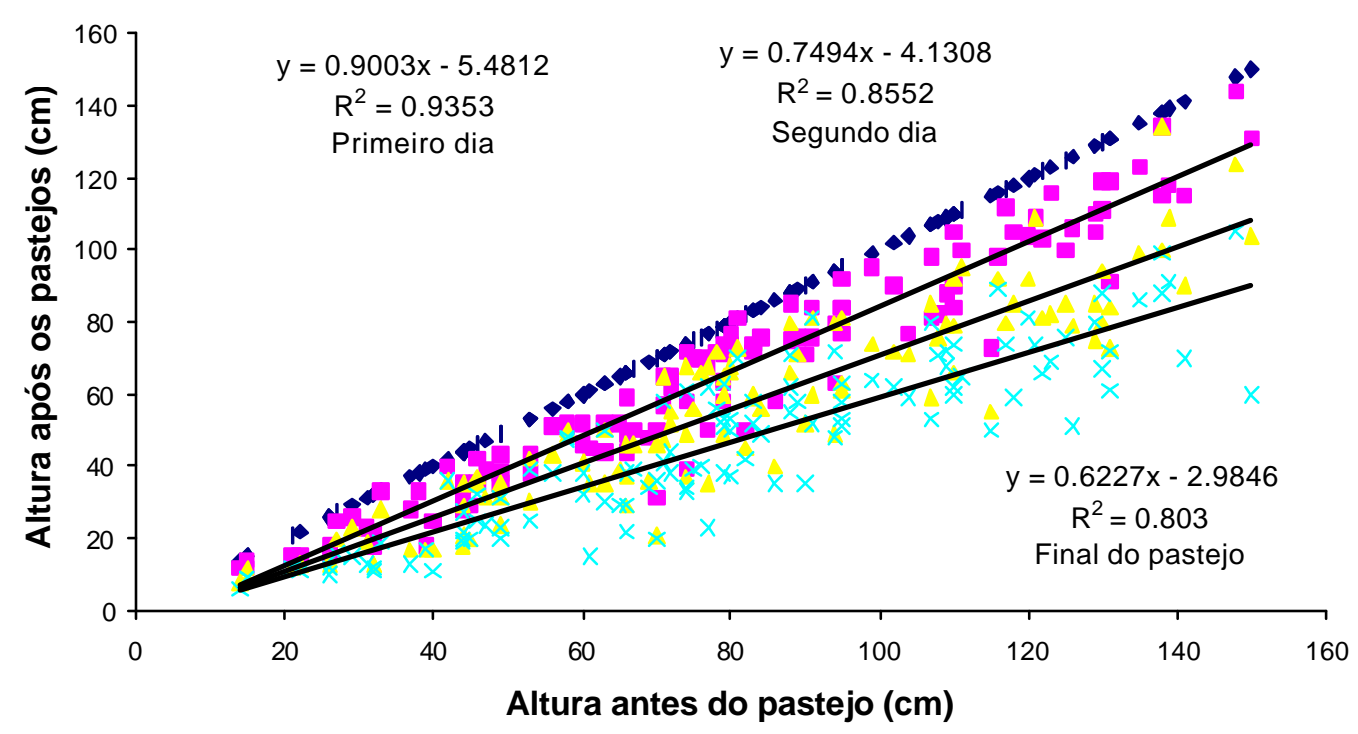

$\bullet$ Antes do pastejo $\square$ Primeiro dia de pastejo $\triangle$ Segundo dia de pastejo $\times$ Final do pastejo

Figura 19 - Relação entre a altura da planta antes do pastejo e a altura da planta após cada dia de pastejo nos piquetes do tratamento 3.

Os resultados mostram que houve uma resposta linear positiva entre a altura da planta e a profundidade de pastejo independente do tratamento e do dia de pastejo. Esse resultado esta de acordo com os trabalhos de Hodgson (1990) e Hodgson et al. (1994) onde os autores comentam que a profundidade do bocado é proporcional a altura da planta.

Pelas Figuras 20 e 21 observa-se que a profundidade de pastejo não foi afetada pela altura inicial das plantas independente do tratamento e do dia de pastejo. As correlações entre a altura das plantas antes do pastejo e a altura relativa das plantas após cada pastejo foram baixas ou seja independente da altura do pasto as plantas foram consumidas proporcionalmente a sua altura. A altura das plantas no último dia de pastejo foi cerca de $40 \%$ da altura inicial independente do tratamento. Esse resultado é semelhante ao valor de $40 \mathrm{a}$ $50 \%$ registrado por Brâncio et al. (2000). 


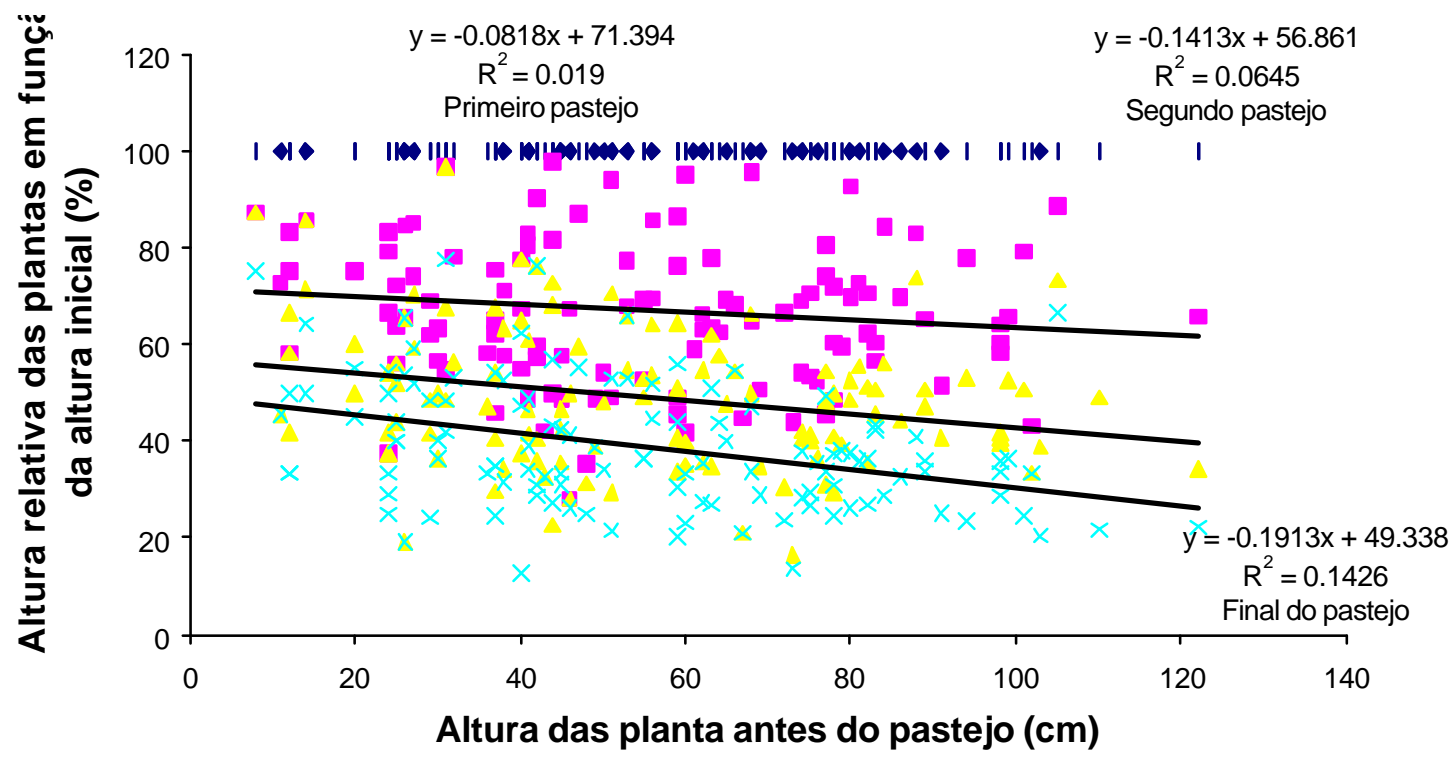

- Antes do pastejo $\quad$ Primeiro dia de pastejo $\triangle$ Segundo dia de pastejo $\times$ Final do pastejo

Figura 20 - Relação entre a altura da planta antes do pastejo e o porcentual da altura inicial da planta (antes do pastejo) em cada dia de pastejo nos piquetes do tratamento 1 . 


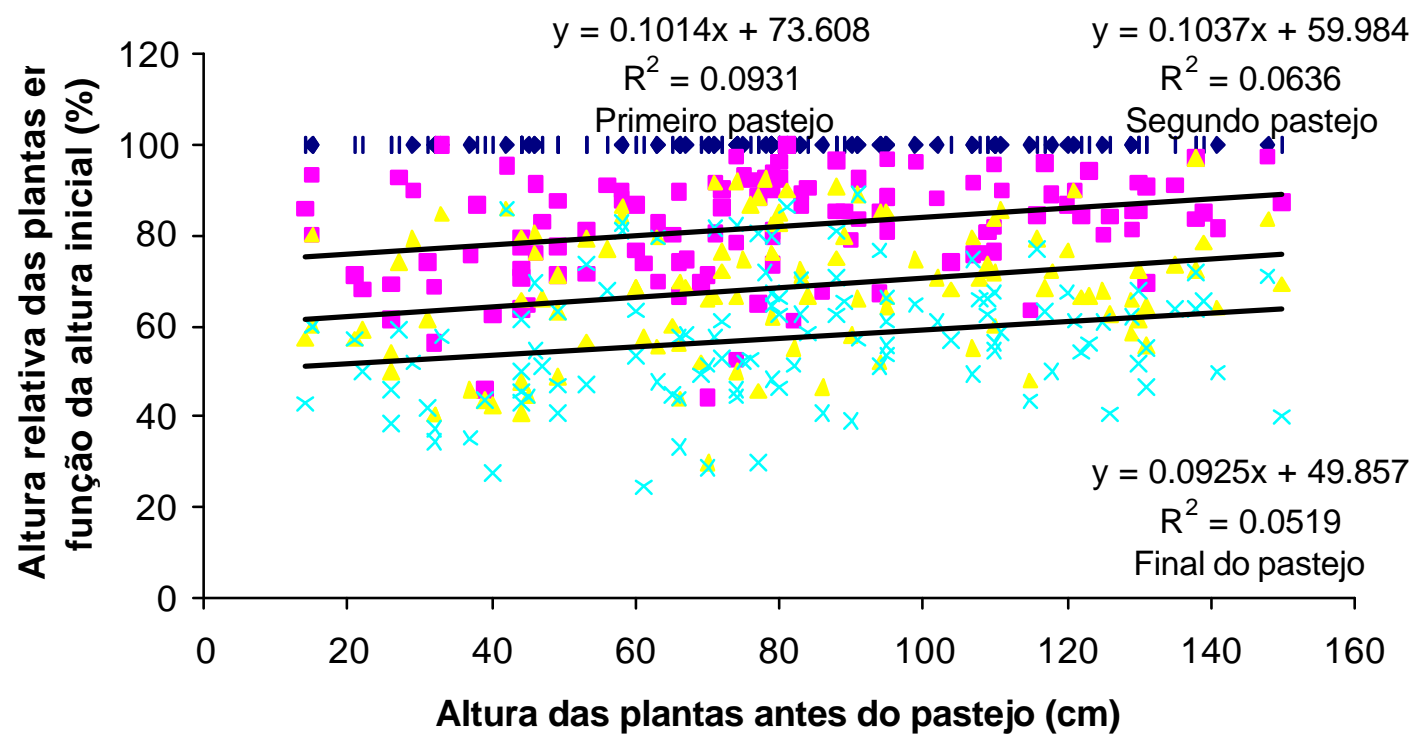

I Antes do pastejo $\square$ Primeiro dia de pastejo $\triangle$ Segundo dia de pastejo $\times$ Final do pastejo

Figura 21 - Relação entre a altura da planta antes do pastejo e o porcentual da altura inicial da planta (antes do pastejo) em cada dia de pastejo nos piquetes do tratamento 3 . 


\subsection{Massa de forragem e altura do pasto após pastejo (resíduo)}

O ajuste da carga de animal nos piquetes era realizado para manter a massa de forragem verde pós pastejo ou do resíduo (MFVR) igual a 1000, 2500 e $4000 \mathrm{~kg} / \mathrm{ha}$ matéria seca verde (MSV) para os tratamentos de baixa (T1), média (T2) e alta (T3) massa de forragem no resíduo, respectivamente. Os valores médios da MFVR observados no final do experimento (Tabela 12) ficaram próximos dos valores propostos, entretanto eles não foram constantes entre as épocas. Apesar disso, quando analisamos a MFVR dentro de cada época, observamos diferenças entre os tratamentos, com exceção da época 3 onde o T2 e T3 foram semelhantes mas superiores ao T1 (Tabela 12).

Tabela 12. Massa de forragem verde pós pastejo (resíduo) (MFVR) em função dos tratamentos e das épocas do ano ${ }^{1}$.

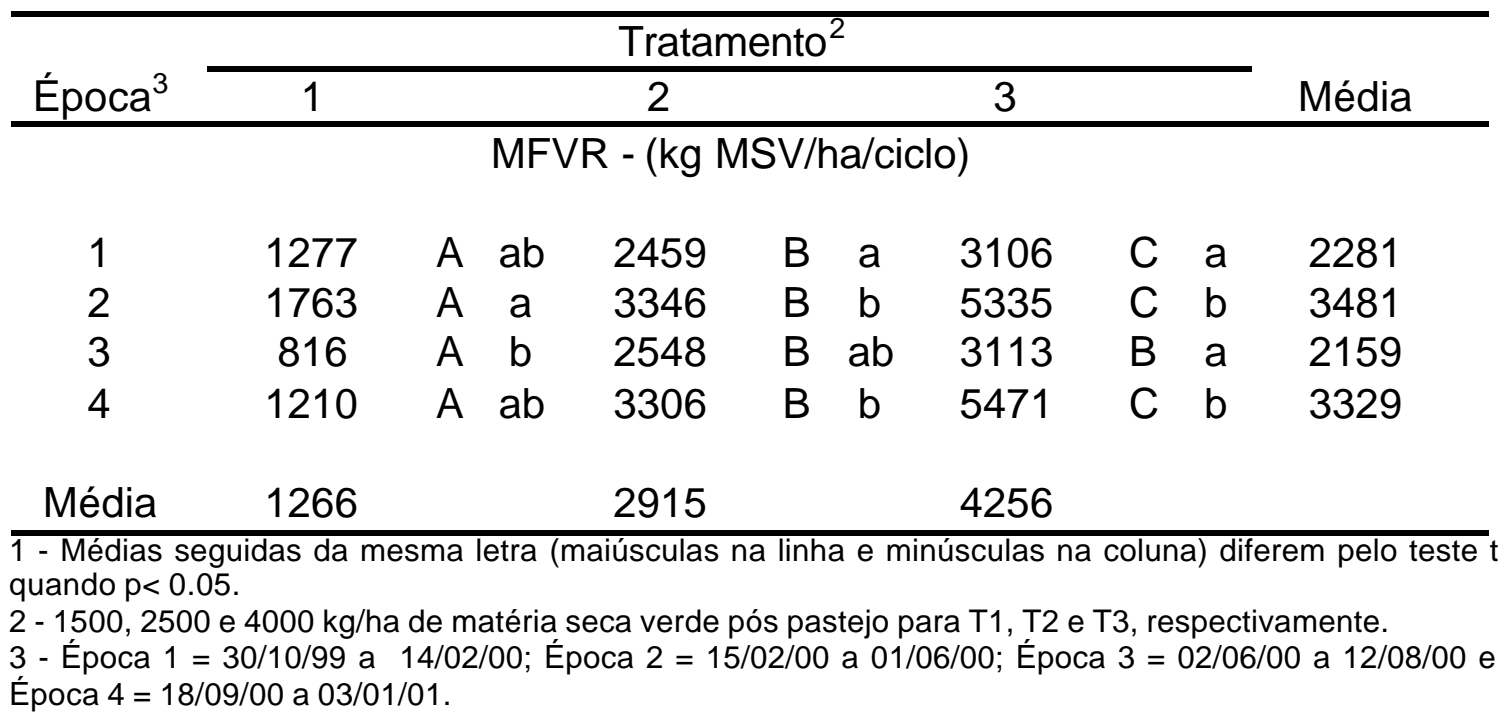

A altura média das plantas após os pastejos (AR) apresentou comportamento semelhante ao da MFVR. A AR diferiu entre os tratamentos independente da época, entretanto, ela variou entre as épocas (Tabela 13). A AR nas épocas 1 e 3 foram iguais entre si mas inferiores às alturas das épocas 
2 e 4, independente do tratamento. Comparando as análises estatísticas da MFVR e da AR, expostas nas Tabelas 12 e 13, observa-se que os resultados da altura pós pastejo apresentaram menores variações do que a massa de forragem. Com esse resultado mais o respaldo da afirmação de Hodgson et al. (1994) de que a altura é mais fácil de aferir do que a massa de forragem, podese sugerir que o manejo das pastagens deveria ser feito com base na altura pós pastejo em vez de considerar a massa de forragem pós pastejo.

Tabela 13. Altura média das plantas no resíduo (AR) em função dos tratamentos e das épocas do ano ${ }^{1}$.

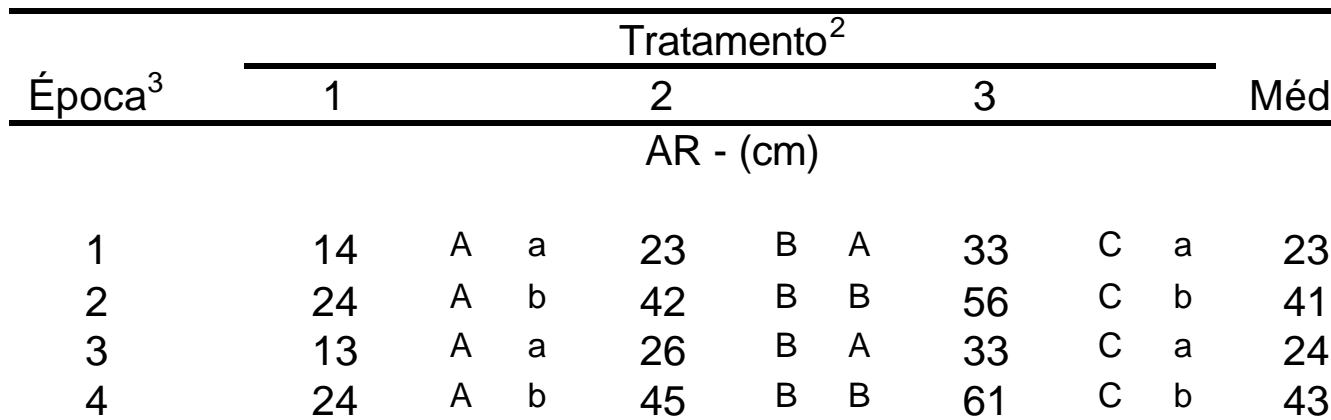

$\begin{array}{llll}\text { Média } & 19 & 34 & 46\end{array}$

1 - Médias seguidas da mesma letra (maiúsculas na linha e minúsculas na coluna) diferem pelo teste $t$ quando $p<0.05$

2 - 1500, 2500 e $4000 \mathrm{~kg} / \mathrm{ha}$ de matéria seca verde pós pastejo para T1, T2 e T3, respectivamente.

3 - Época 1 = 30/10/99 a 14/02/00; Época 2 = 15/02/00 a 01/06/00; Época $3=02 / 06 / 00$ a 12/08/00 e Época $4=18 / 09 / 00$ a 03/01/01.

As variações observadas na MFVR e na $A R$ durante o período experimental deve se a mudanças nas características morfológicas da planta como apresentado no item 4.4. Nas épocas de maior produção de MFVR (épocas 2 e 4) a participação da haste na planta antes do pastejo (HP\%) também foram superiores às épocas 1 e 3 (Tabela 15). Dessa forma os animais deveriam consumir mais haste para atender os valores propostos de MFVR e assim o desempenho dos animais poderia ser comprometido. Esse fato seria mais marcante na época 2 pois a haste estava em pleno processo de alongamento e bastante lignificada. $\mathrm{Na}$ época 1 a $\mathrm{HP} \%$ também foi alta 
entretanto a relação folha/haste nas plantas antes do pastejo (FHP) foi maior do que nas outras épocas (Tabela 14). Além disso, a qualidade da haste nessa época é alta porque coincide com o inicio da rebrota dos pastos ou seja as haste são tecidos jovens e dessa forma não limitara o seu consumo pelo animal (Balsalobre, 1996).

\subsection{Relação entre características morfológicas da planta e do manejo sobre o desenvolvimento das pastagens}

A relação folha/haste é alterada com o manejo das pastagens (Peternelli et al., 2000; Aguiar et al., 2001) e tem efeito sobre o consumo animal (Gomide \& Gomide, 2001).

Nesse trabalho a relação folha/haste nas plantas antes do pastejo (FHP) aumentaram com a severidade do pastejo (Tabela 14) conforme observado também por Peternelli et al. (2000). As diferenças observadas na FHP entre os tratamentos esta mais associada com a variação na participação da haste (HP\%) entre os tratamentos do que com a participação das folhas na planta (FP\%) pois a HP\% diferiu entre todos os tratamentos o que não ocorreu com a FP\% entre os T2 e T3 conforme pode ser observado nas Tabelas 15 e 16. Dessa forma também podemos inferir que o efeito dos tratamentos foi maior na $\mathrm{HP} \%$ do que na FP\%.

A FHP também diferiu durante o período experimental. A FHP diminuiu da época 1 para a 2 devido ao processo de alongamento das hastes no estádio que precede o florescimento (abril a maio) e depois, nas épocas 3 e 4, a FHP aumentou novamente mas àníveis inferiores ao da época 1. A redução da FHP na época 2 foi resultado do aumento na média da produção de haste associado a manutenção da produção de folhas conforme pode ser observado nas Tabelas 17 e 18. 
Tabela 14. Relação folha/haste média nas plantas antes dos pastejos (FHP) em função dos tratamentos e das épocas de ano ${ }^{1}$.

\begin{tabular}{|c|c|c|c|c|c|}
\hline \multirow[b]{2}{*}{ Época $^{3}$} & \multicolumn{3}{|c|}{ Tratamento $^{2}$} & \multirow{2}{*}{\multicolumn{2}{|c|}{ Média }} \\
\hline & 1 & 2 & 3 & & \\
\hline \multicolumn{6}{|c|}{$\mathrm{FHP}$} \\
\hline 1 & 1,9 & 1,6 & 1,3 & 1,6 & $a$ \\
\hline 2 & 1,0 & 0,7 & 0,5 & 0,7 & b \\
\hline 3 & 1,7 & 0,8 & 0,6 & 1,0 & c \\
\hline 4 & 1,2 & 1,0 & 1,0 & 1,1 & c \\
\hline
\end{tabular}

$\begin{array}{lllllll}\text { Média } & 1,4 & \mathrm{~A} & 1,0 & \mathrm{~B} & 0,9 & \mathrm{C}\end{array}$

1 - Médias seguidas da mesma letra (maiúsculas na linha e minúsculas na coluna) diferem pelo teste $\mathrm{t}$ quando $\mathrm{p}<0.05$.

2 - 1500, 2500 e $4000 \mathrm{~kg} / \mathrm{ha}$ de matéria seca verde pós pastejo para T1, T2 e T3, respectivamente.

3 - Época 1 = 30/10/99 a 14/02/00; Época 2 = 15/02/00 a 01/06/00; Época $3=02 / 06 / 00$ a 12/08/00 e Época 4 = 18/09/00 a 03/01/01.

Tabela 15. Participação média de haste nas plantas antes dos pastejos (HP\%) em função dos tratamentos e das épocas do ano ${ }^{1}$.

\begin{tabular}{|c|c|c|c|c|c|c|c|c|}
\hline \multirow[b]{2}{*}{ Época $^{3}$} & \multicolumn{6}{|c|}{ Tratamento $^{2}$} & \multirow{2}{*}{\multicolumn{2}{|c|}{ Média }} \\
\hline & 1 & & 2 & & 3 & & & \\
\hline \multicolumn{9}{|c|}{ HP\% } \\
\hline 1 & $28 \%$ & & $31 \%$ & & $35 \%$ & & $31 \%$ & a \\
\hline 2 & $38 \%$ & & $45 \%$ & & $50 \%$ & & $44 \%$ & b \\
\hline 3 & $16 \%$ & & $22 \%$ & & $26 \%$ & & $21 \%$ & c \\
\hline 4 & $35 \%$ & & $36 \%$ & & $38 \%$ & & $36 \%$ & $d$ \\
\hline Média & $29 \%$ & A & $33 \%$ & B & $37 \%$ & C & & \\
\hline $\begin{array}{l}1 \text { - Médias } \\
\text { quando } \mathrm{p}<0 \\
2-1500,250 \\
3-\text { Epoca } 1 \\
\text { Énoca } 4=18\end{array}$ & $\begin{array}{l}\mathrm{a} 144 \\
01 / 01\end{array}$ & & & & & & & $\begin{array}{l}\text { ste t } \\
00 \mathrm{e}\end{array}$ \\
\hline
\end{tabular}


Tabela 16. Participação média de folhas nas plantas antes dos pastejos (FP\%) em função dos tratamentos e das épocas do ano ${ }^{1}$.

\begin{tabular}{|c|c|c|c|c|c|c|c|c|}
\hline \multirow[b]{2}{*}{ Época ${ }^{3}$} & \multicolumn{6}{|c|}{ Tratamento $^{2}$} & \multirow{2}{*}{\multicolumn{2}{|c|}{ Média }} \\
\hline & 1 & & 2 & & 3 & & & \\
\hline \multicolumn{9}{|c|}{ FP\% } \\
\hline 1 & $54 \%$ & & $50 \%$ & & $46 \%$ & & $50 \%$ & a \\
\hline 2 & $42 \%$ & & $37 \%$ & & $33 \%$ & & $37 \%$ & $b$ \\
\hline 3 & $31 \%$ & & $21 \%$ & & $21 \%$ & & $24 \%$ & C \\
\hline 4 & $45 \%$ & & $39 \%$ & & $40 \%$ & & $41 \%$ & $d$ \\
\hline Média & $43 \%$ & A & $37 \%$ & $\mathrm{~B}$ & $35 \%$ & $\mathrm{~B}$ & & \\
\hline \multicolumn{9}{|c|}{$\begin{array}{l}1 \text { - Médias seguidas da mesma letra (maiúsculas na linha e minúsculas na coluna) diferem pelo teste } \\
\text { quando } p<0.05 \text {. } \\
2-1500,2500 \text { e } 4000 \mathrm{~kg} / \mathrm{ha} \text { de matéria seca verde pós pastejo para T1, T2 e T3, respectivamente. } \\
3 \text { - Época } 1=30 / 10 / 99 \text { a } 14 / 02 / 00 ; \text { Época } 2=15 / 02 / 00 \text { a 01/06/00; Época } 3=02 / 06 / 00 \text { a } 12 / 08 / 00 \\
\text { Época } 4=18 / 09 / 00 \text { a 03/01/01. }\end{array}$} \\
\hline
\end{tabular}

Tabela 17. Produção média de haste antes dos pastejos (HPHA) em função dos tratamentos e das épocas do ano ${ }^{1}$.

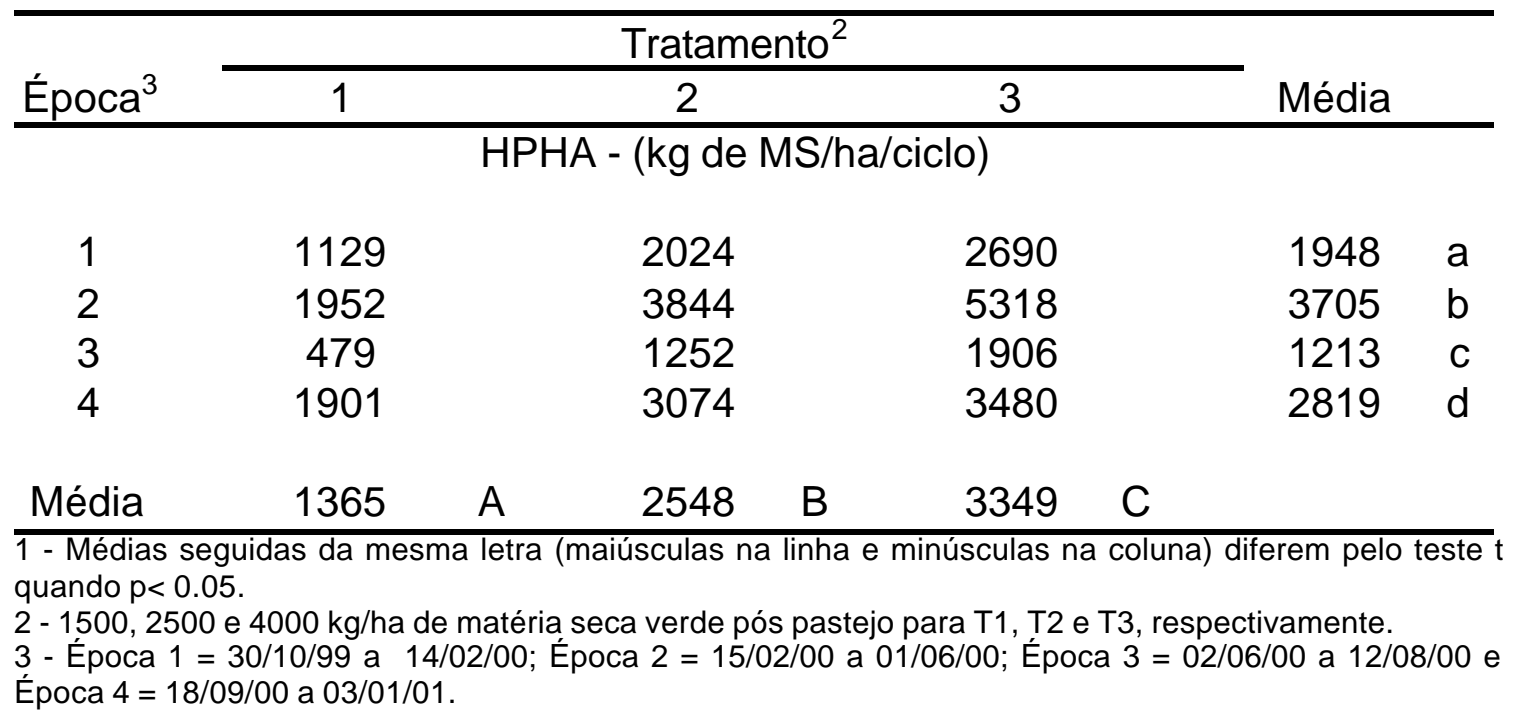


Tabela 18. Produção média de folhas antes do pastejo (FPHA) em função dos tratamentos e das épocas do ano ${ }^{1}$.

\begin{tabular}{|c|c|c|c|c|c|c|c|c|}
\hline \multirow[b]{2}{*}{ Época ${ }^{3}$} & \multicolumn{6}{|c|}{ Tratamento $^{2}$} & \multirow{2}{*}{\multicolumn{2}{|c|}{ Média }} \\
\hline & 1 & & 2 & & 3 & & & \\
\hline \multicolumn{9}{|c|}{ FPHA - (kg de MS/ha/ciclo) } \\
\hline 1 & 2116 & & 3185 & & 3433 & & 2911 & a \\
\hline 2 & 2115 & & 2930 & & 3292 & & 2779 & a \\
\hline 3 & 769 & & 975 & & 1199 & & 981 & b \\
\hline 4 & 2394 & & 3159 & & 3493 & & 3015 & a \\
\hline Média & 1849 & A & 2562 & B & 2854 & B & & \\
\hline $\begin{array}{l}1 \text { - Médias } \\
\text { quando } p< \\
2-1500,25 \\
3 \text { - Época } \\
\text { Época } 4=1\end{array}$ & $\begin{array}{l}\text { a } 14 / 0 \\
3 / 01 / 01\end{array}$ & & ulas na & & ; Époc & 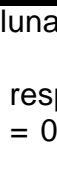 & $\begin{array}{l}\text { nente. } \\
\text { a } 12 / 08\end{array}$ & \\
\hline
\end{tabular}

Esse fato mostra a importância de determinar práticas de manejo de pastagens ou de outras práticas agronômicas, como por exemplo o uso de reguladores vegetais (Penati et al., 2000), para conter o alongamento da haste, uma vez que, esse tecido tem baixo valor nutritivo e baixa preferência pelos animais Paiva et al. (2001), Balsalobre (1996) e Teixeira (1998).

Esse comportamento também foi observado na produção de material morto nas plantas antes do pastejo (MMPHA) (Tabela 19). Entretanto, ao contrário do que ocorreu com MMP\% (Tabela 20), a MMPHA foi afetada pela MFVR. No T1 foi observado a menor MMPHA e não foi encontrada diferença entre os T2 e T3. Esses resultados estão coerentes com as observações realizadas por Paiva et al. (2001) onde a produção de material morto aumentou com o avanço do período experimental (janeiro a outubro) e com o aumento na disponibilidade de forragem. 
Tabela 19. Produção média de material morto antes dos pastejos (MMPHA) em função dos tratamentos e das épocas do ano ${ }^{1}$.

\begin{tabular}{|c|c|c|c|c|c|c|c|c|}
\hline \multirow[b]{2}{*}{ Época $^{3}$} & \multicolumn{6}{|c|}{ Tratamento $^{2}$} & \multirow{2}{*}{\multicolumn{2}{|c|}{ Média }} \\
\hline & 1 & & 2 & & 3 & & & \\
\hline \multicolumn{9}{|c|}{ MMPHA (kg de MS/ha/ciclo) } \\
\hline 1 & 731 & & 1235 & & 1450 & & 1138 & a \\
\hline 2 & 921 & & 1506 & & 1659 & & 1362 & b \\
\hline 3 & 1485 & & 2854 & & 2960 & & 2433 & c \\
\hline 4 & 1070 & & 2104 & & 2063 & & 1746 & d \\
\hline Média & 1051 & A & 1925 & B & 2033 & B & & \\
\hline $\begin{array}{l}1-\text { Médias } \\
q \text { quando } p<0 \\
2-1500,25\end{array}$ & $\begin{array}{l}14 / 02 \\
1 / 01\end{array}$ & & & & s na col & & 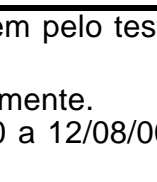 & \\
\hline
\end{tabular}

Tabela 20. Participação média de material morto nas plantas antes dos pastejos (MMP\%) em função dos tratamentos e das épocas do ano ${ }^{1}$.

\begin{tabular}{cccccc}
\hline & \multicolumn{4}{c}{ Tratamento $^{2}$} & \\
\cline { 2 - 4 } Época $^{3}$ & 1 & 2 & 3 & Média \\
\hline & & MMP\% & & & \\
1 & $17 \%$ & $19 \%$ & $19 \%$ & $19 \%$ & a \\
2 & $20 \%$ & $18 \%$ & $18 \%$ & $19 \%$ & a \\
3 & $53 \%$ & $58 \%$ & $53 \%$ & $54 \%$ & b \\
4 & $20 \%$ & $25 \%$ & $23 \%$ & $23 \%$ & c
\end{tabular}

$\begin{array}{lllllll}\text { Média } & 28 \% & \mathrm{~A} & 30 \% & \mathrm{~A} & 28 \% & \mathrm{~A}\end{array}$

1 - Médias seguidas da mesma letra (maiúsculas na linha e minúsculas na coluna) diferem pelo teste $t$ quando $\mathrm{p}<0.05$.

2 - 1500, 2500 e $4000 \mathrm{~kg} / \mathrm{ha}$ de matéria seca verde pós pastejo para T1, T2 e T3, respectivamente.

3 - Época $1=30 / 10 / 99$ a 14/02/00; Época $2=15 / 02 / 00$ a 01/06/00; Época $3=02 / 06 / 00$ a 12/08/00 e Época $4=18 / 09 / 00$ a 03/01/01.

Mudanças na estrutura morfológica da planta podem afetar a densidade de forragem ( $\mathrm{kg} \mathrm{MS} / \mathrm{cm} / \mathrm{ha}$ ) que também é outra característica que interfere no 
consumo de pastagens pelo animal (Burns et al., 1991; Carvalho et al., 2001b). Entretanto, a MFVR não afetou a densidade de forragem antes do pastejo (DP) (Tabela 21) apesar das alterações ocorridas na relação HFP, HP\%, FP\% e MMP\% entre os tratamentos, como já discutido. As alterações na HFP, HP\%, FP\% e MMP\% poderiam explicar as diferenças observadas na DP entre as épocas de pastejo como também foi observado por Silva et al. (1994). Esses autores observaram em pastagens formadas com capim Elefante anão, que a densidade de forragem não foi afetada pela oferta de forragem mas ela foi alterada durante o período experimental. Esses autores determinaram que a densidade de forragem aumenta do estrato superior do dossel parra os estratos mais baixos.

Tabela 21. Densidade média de forragem antes dos pastejos (DP) em função dos tratamentos e das épocas do ano ${ }^{1}$.

\begin{tabular}{|c|c|c|c|c|c|}
\hline \multirow[b]{2}{*}{ Época ${ }^{3}$} & \multicolumn{3}{|c|}{ Tratamento $^{2}$} & \multirow{2}{*}{\multicolumn{2}{|c|}{ Média }} \\
\hline & 1 & 2 & 3 & & \\
\hline \multicolumn{6}{|c|}{ DP - (kg MS/cm/ha/ciclo) } \\
\hline 1 & 104 & 105 & 99 & 103 & $a b$ \\
\hline 2 & 91 & 98 & 101 & 96 & bc \\
\hline 3 & 101 & 115 & 107 & 107 & $a b$ \\
\hline 4 & 79 & 89 & 91 & 86 & c \\
\hline
\end{tabular}

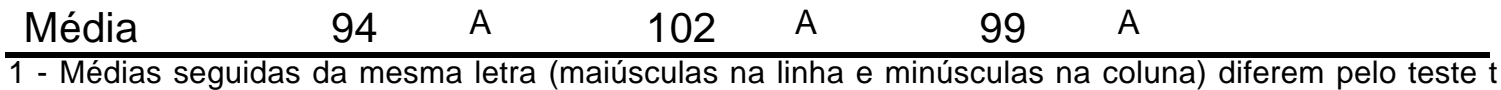
quando $\mathrm{p}<0.05$.

2 - 1500, 2500 e $4000 \mathrm{~kg} / \mathrm{ha}$ de matéria seca verde pós pastejo para T1, T2 e T3, respectivamente. 3 - Época 1 = 30/10/99 a 14/02/00; Época 2 = 15/02/00 a 01/06/00; Época $3=02 / 06 / 00$ a 12/08/00 e Época 4 = 18/09/00 a 03/01/01.

A ausência do efeito da MFVR sobre a densidade pode ser explicado pela forte relação entre a altura e massa de forragem durante o experimento como pode ser observado na Figura 22 pois a densidade é a relação entre a massa de forragem dividida pela altura. Dessa forma a densidade de forragem 
será sempre semelhante pois, o aumento na produção de forragem foi relacionado com o aumento da altura.

Apesar da análise estatística detectar diferenças na DP entre épocas, as variações entre as DP não foram acentuadas pois as épocas 1, 2 e 3 foram iguais e a época 4, que foi diferente das épocas 1 e 3, não diferiu da época 2, ou seja, não existe uma definição clara do efeito das épocas de pastejo sobre DP.

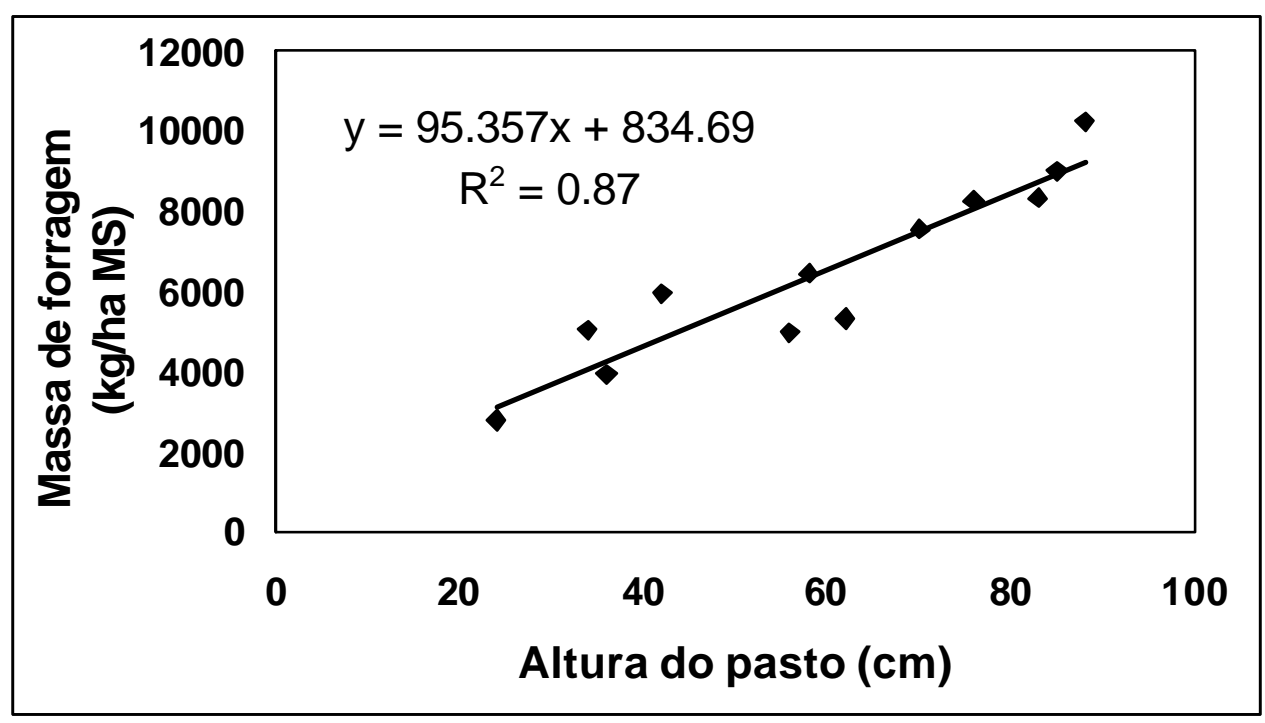

Figura 22 - Relação entre altura da pastagem antes do pastejo com a massa de forragem.

Diferenças na DP no perfil das pastagens também foram observadas nesse experimento como no trabalho de Silva et al. (1994). Porém, essa distribuição foi pouco alterada pela MFVR pois, como pode ser observado na Tabela 22, somente nos estratos 5 e 6 a densidade do T3 foi superior a densidade do T1 e no restante dos estratos não houve diferença entre os tratamentos. No trabalho de Silva et al. (1994) a variação foi maior do que nesse trabalho. A diferença entre os resultados pode ser explicado pela forma como o perfil foi estratificado. Nesse trabalho, o tamanho (comprimento) dos 
estratos são proporcionais a altura da planta e assim, o estrato de uma planta alta é maior (mais comprido) do que o estrato de uma planta mais baixa enquanto que, no trabalho de Silva et al. (1994), os estratos foram separados a intervalos fixos de $10 \mathrm{~cm}$, independente da altura das plantas.

Tabela 22. Densidade média de forragem antes dos pastejos (DPE) em vários estratos do perfil do dossel em função dos tratamentos ${ }^{1}$ sem considerar o estrato correspondente ao resíduo (7).

\begin{tabular}{|c|c|c|c|c|c|c|c|c|c|c|}
\hline \multirow[b]{2}{*}{ Estrato $^{3}$} & \multicolumn{9}{|c|}{ Tratamento $^{2}$} & \multirow[b]{2}{*}{ Média } \\
\hline & 1 & & & 2 & & & 3 & & & \\
\hline \multicolumn{11}{|c|}{ DPE - (Kg MS/cm/ha) } \\
\hline 1 & 5 & A & a & 5 & A & a & 9 & A & a & 6 \\
\hline 2 & 16 & $A$ & b & 16 & $A$ & $b$ & 22 & $A$ & $b$ & 18 \\
\hline 3 & 44 & A & C & 44 & A & C & 55 & A & C & 48 \\
\hline 4 & 53 & A & $d$ & 53 & $A$ & $d$ & 58 & $A$ & c & 55 \\
\hline 5 & 71 & A & e & 71 & $A B$ & e & 68 & B & $d$ & 70 \\
\hline 6 & 86 & A & $f$ & 86 & $B$ & $f$ & 74 & $B$ & $d$ & 82 \\
\hline Média & 46 & & & 46 & & & 48 & & & \\
\hline
\end{tabular}

O problema de compararmos estratos que foram definidos sem levar em consideração a altura da planta pode levar a erros por compararmos estratos que estão na mesma altura mas apresentam característica morfológicas diferentes como por exemplo, quando a parte superior de uma planta baixa é comparada com o estrato intermediário de uma planta alta. O estudo de estratos parece mais lógico quando consideramos o comportamento animal uma vez que o consumo da forragem é proporcional a altura da planta. (Figuras 18, 19, 20 e 21). Desse modo, a melhor indicação parece ser a de definir os estratos levando em consideração a altura da planta do que estabelece-los com o mesmo comprimento dos extratos principalmente quando existe a intenção de 
relacionar as características morfológicas de cada estrato com as avaliações de consumo e/ou comportamento animal.

Nesse mesmo sentido, outro aspecto que não é levado em consideração quando estudamos a distribuição da densidade de forragem em vários estratos do dossel é o formato da planta. A touceira estabelecida por plantas de Tanzânia tem a forma de um cone invertido e assim a massa de forragem correspondente a um estrato, principalmente nos inferiores, se concentra em uma área ou volume menor do que a massa de forragem do estrato superior aumentando a densidade de forragem nas camadas inferiores como apresentado na Tabela 23. Os resultados da Tabela 23 indicam que, considerando o formato das touceiras a densidade de forragem seria de 52 a $121 \mathrm{~kg} \mathrm{MS} / \mathrm{cm} /$ ha nos estratos 3 e 6 respectivamente, comparado com as densidades de 48 e $82 \mathrm{~kg} \mathrm{MS} / \mathrm{cm} / \mathrm{ha}$ (Tabela 22) se o formato da planta não for considerado.

Os dados da Tabela 23 indicam que nos estratos superiores (1 e 2) a densidade variou de 7 a $19 \mathrm{~kg} \mathrm{MS} / \mathrm{cm} / \mathrm{ha}$ enquanto que nos estratos inferiores essa densidade é maior do que o dobro do anterior. Esse fato mostra que para o comportamento animal é mais interessante analisar os estratos inferiores que, além de representara maior parte da produção de forragem, também tem a maior densidade.

Para estimar a densidade de forragem corrigida em função do formato da planta é necessário conhecer a taxa de ocupação do solo pelas touceiras (TO) e o formato da planta para ajustar a DP em função da distribuição espacial das plantas na área. Conforme observa-se na Tabela 24, a TO no inicio do experimento (época 1) era de $41 \%$ e na época 4 foi para $25 \%$ e se manteve estável até a época 5. Portanto, podemos considerar que a TO parece ter estabilizada em cerca de $24 \%$. Desse modo, podemos inferir que a área e/ou volume médio ocupado pelas plantas entouceiradas corresponde a $62 \%$ $((100 \%+24 \%) / 2)$ da área e/ou volume do dossel. Nesse caso, se a densidade de forragem for estimada em $100 \mathrm{~kg} \mathrm{MS} / \mathrm{cm} / \mathrm{ha}$, quando levamos em 
consideração o formato da planta a densidade (efetivamente ofertada aos animais) aumenta para $161 \mathrm{~kg} \mathrm{MS} / \mathrm{cm} / \mathrm{ha}(100 / 0,62)$ o que, provavelmente, devera favorecer o consumo da forragem pelos animais.

Tabela 23. Densidade de forragem antes do pastejo em vários estratos do perfil do dossel em função dos tratamentos e corrigido pelo formato da planta $(\mathrm{DPEC})^{1}$ sem considerar o estrato correspondente ao resíduo (7).

\begin{tabular}{ccccccc}
\hline & \multicolumn{4}{c}{ Tratamentos $^{2}$} & & Média \\
\cline { 2 - 4 } Estrato $^{3}$ & 1 & 2 & 3 & & & \\
& \multicolumn{5}{c}{ DPEC - Kg MS/cm/ha } \\
1 & 5 & 7 & 9 & 7 & $\mathrm{a}$ \\
2 & 16 & 20 & 22 & 19 & $\mathrm{~b}$ \\
3 & 49 & 50 & 57 & 52 & $\mathrm{c}$ \\
4 & 67 & 74 & 65 & 69 & $\mathrm{~d}$ \\
5 & 105 & 89 & 80 & 91 & $\mathrm{e}$ \\
6 & 155 & 116 & 93 & 121 & $\mathrm{f}$
\end{tabular}

$\begin{array}{lllllll}\text { Média } & 66 & \text { A } & 59 & \text { A } & 54 & \text { A }\end{array}$

1 - Médias seguidas da mesma letra (maiúsculas na linha e minúsculas na coluna) diferem pelo teste $t$ quando $p<0.05$.

2 - 1500, 2500 e $4000 \mathrm{~kg} / \mathrm{ha}$ de matéria seca verde pós pastejo para T1, T2 e T3, respectivamente.

3 - Os estratos 1 e 6 correspondem aos estratos mais alto e baixo do perfil do dossel, respectivamente.

Mudanças na TO do solo pelas plantas pode ser reflexo de um processo de adaptação das plantas na comunidade. No inicio desse experimento as altas TO deve-se ao fato do plantio ter sido recente e das sementes terem sido distribuídas em linha bem próximas $(17 \mathrm{~cm})$ ou seja, praticamente toda a área estava ocupada com plantas de Tanzânia.

Com o decorrer do experimento as touceiras se formaram e ficaram mais caracterizadas nas pastagens apesar da TO diminuir (Tabela 24). Entretanto, o tamanho das touceiras (TT) diferiu em função dos tratamentos e da época do ano. Pelo dados apresentados na Tabela 25 observa-se que a porcentagem de 
touceiras com 1 e 2 pontos ( touceiras menores) foram semelhantes entre os tratamentos nas épocas 1 e 5 e houve diferença entre os tratamentos nas épocas 2, 3 e 4. Na época 1 não houve diferenças entre os TT porque estava começando o manejo diferenciado dos pastos e não houve tempo suficiente para o TT ser afetado pela MFVR.

Tabela 24. Taxa de ocupação do solo pela área basal da touceira (TO) em função dos tratamentos e das épocas do ano ${ }^{1}$.

\begin{tabular}{ccccccc}
\hline & \multicolumn{3}{c}{ Tratamento $^{2}$} & & \\
$n_{\text {Época }}{ }^{3}$ & 1 & 2 & 3 & & Média \\
\hline & & TO - \% & & & \\
& & & $38 \%$ & $41 \%$ & a \\
1 & $41 \%$ & $45 \%$ & $37 \%$ & $39 \%$ & a \\
2 & $40 \%$ & $39 \%$ & $31 \%$ & $31 \%$ & $\mathrm{c}$ \\
3 & $31 \%$ & $31 \%$ & $28 \%$ & $25 \%$ & $\mathrm{~d}$ \\
4 & $22 \%$ & $24 \%$ & $20 \%$ & $24 \%$ & $\mathrm{~d}$
\end{tabular}

$\begin{array}{lllllll}\text { Média } & 32 \% & \mathrm{~A} & 33 \% & \mathrm{~A} & 31 \% & \mathrm{~A}\end{array}$

1 - Médias seguidas da mesma letra (maiúsculas na linha e minúsculas na coluna) diferem pelo teste $t$ quando $\mathrm{p}<0.05$.

2 - 1500, 2500 e $4000 \mathrm{~kg} / \mathrm{ha}$ de matéria seca verde pós pastejo para T1, T2 e T3, respectivamente.

3 - Época 1 = 30/10/99 a 14/02/00; Época $2=15 / 02 / 00$ a 01/06/00; Época $3=02 / 06 / 00$ a 12/08/00; Época $4=18 / 09 / 00$ a 03/01/01 e Época $5=04 / 01 / 01$ a 06/08/01.

Nas época 2, 3 e 4 observa-se o efeito do manejo sobre o TT pois o T2 e T3 foram superiores ao T1 mas, iguais entre si. Na época 5 os TT voltaram a serem iguais entre os tratamentos entretanto pode-se observar que houve uma redução no TT no T1 entre as épocas 4 e 5 . Esse fato ocorreu porque durante a época 5 o manejo dos piquetes passaram a ser realizado para atender $2500 \mathrm{~kg}$ $\mathrm{MSV} /$ ha no resíduo, independente do tratamento. Desse modo o T1 que estava sendo manejado com a menor MFVR (1000 kg/ha MSV) passou a ser manejado mais alto e assim a TT aumentou e passou a ser igual aos valores do T2 e T3.

Entretanto o mesmo efeito não foi observado para TO pois ela não foi alterada pela mudança de manejo realizada na época 5 . Desse fato podemos 
inferir que em pastagens bem estabelecidas a planta altera primeiro a TT antes de alterar a TO. Esse raciocínio fica coerente ao observarmos que a produção de forragem na época 4 foi maior do que na época 1 apesar da TO ser menor.

Tabela 25. Porcentagem de touceiras de 1 e 2 pontos em relação ao número total de touceiras em função dos tratamentos e das épocas do ano ${ }^{1}$.

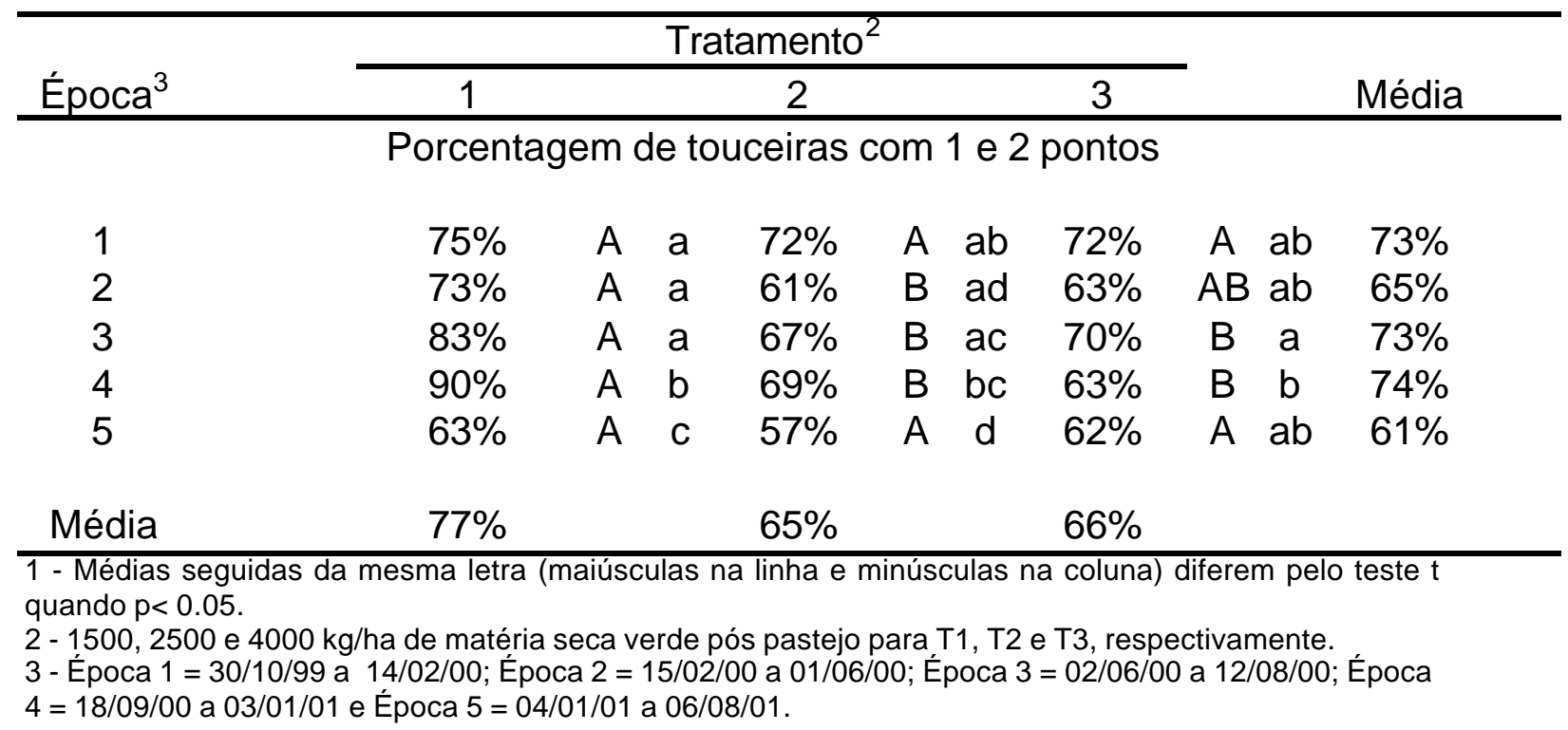

Portanto alteração no TT deve estar associada àmecanismos rápidos de adaptação da planta a mudanças no meio ambiente causadas pelas diferentes intensidade de pastejo. Quando menor a MFVR menor foi a altura das pastagens (Tabela 26) assim como deve ter sido menor o tamanho das folhas (Carvalho et al., 2001b). Essas mudanças reduzem a capacidade da planta de competir por nutrientes, luz e água com outras plantas da comunidade. Dessa forma as plantas devem ficar mais próximas uma das outras para reduzir o tamanho da área a ser sombreada conforme pode ser observado na Figura 23. Quando diminui a distância entre as touceiras o ritmo de crescimento da planta (RC) necessária para sombrear o solo (descoberto ou com outra vegetação) em um determinado tempo pode ser menor do que nas pastagens caracterizadas por touceiras maiores e mais distantes entre si. 
Tabela 26. Altura média das plantas antes dos pastejos (AP) em função dos tratamentos e das épocas do ano ${ }^{1}$.

\begin{tabular}{|c|c|c|c|c|c|}
\hline \multirow[b]{2}{*}{ Época ${ }^{3}$} & \multicolumn{3}{|c|}{ Tratamento $^{2}$} & \multirow[b]{2}{*}{ Média } & \\
\hline & 1 & 2 & 3 & & \\
\hline \multicolumn{5}{|c|}{$\mathrm{AP}(\mathrm{cm})$} & \\
\hline 1 & 36 & 58 & 70 & 54 & a \\
\hline 2 & 56 & 76 & 88 & 74 & $b$ \\
\hline 3 & 24 & 34 & 42 & 33 & c \\
\hline 4 & 62 & 83 & 85 & 77 & b \\
\hline
\end{tabular}

$\begin{array}{lllllll}\text { Média } & 45 & \mathrm{~A} & 63 & \mathrm{~B} & 71 & \mathrm{C}\end{array}$

1 - Médias seguidas da mesma letra (maiúsculas na linha e minúsculas na coluna) diferem pelo teste $t$ quando $\mathrm{p}<0.05$.

2 - 1500, 2500 e $4000 \mathrm{~kg} / \mathrm{ha}$ de matéria seca verde pós pastejo para T1, T2 e T3, respectivamente.

3 - Época 1 = 30/10/99 a 14/02/00; Época $2=15 / 02 / 00$ a 01/06/00; Época $3=02 / 06 / 00$ a 12/08/00; Época $4=18 / 09 / 00$ a 03/01/01 e Época $5=04 / 01 / 01$ a 06/08/01.

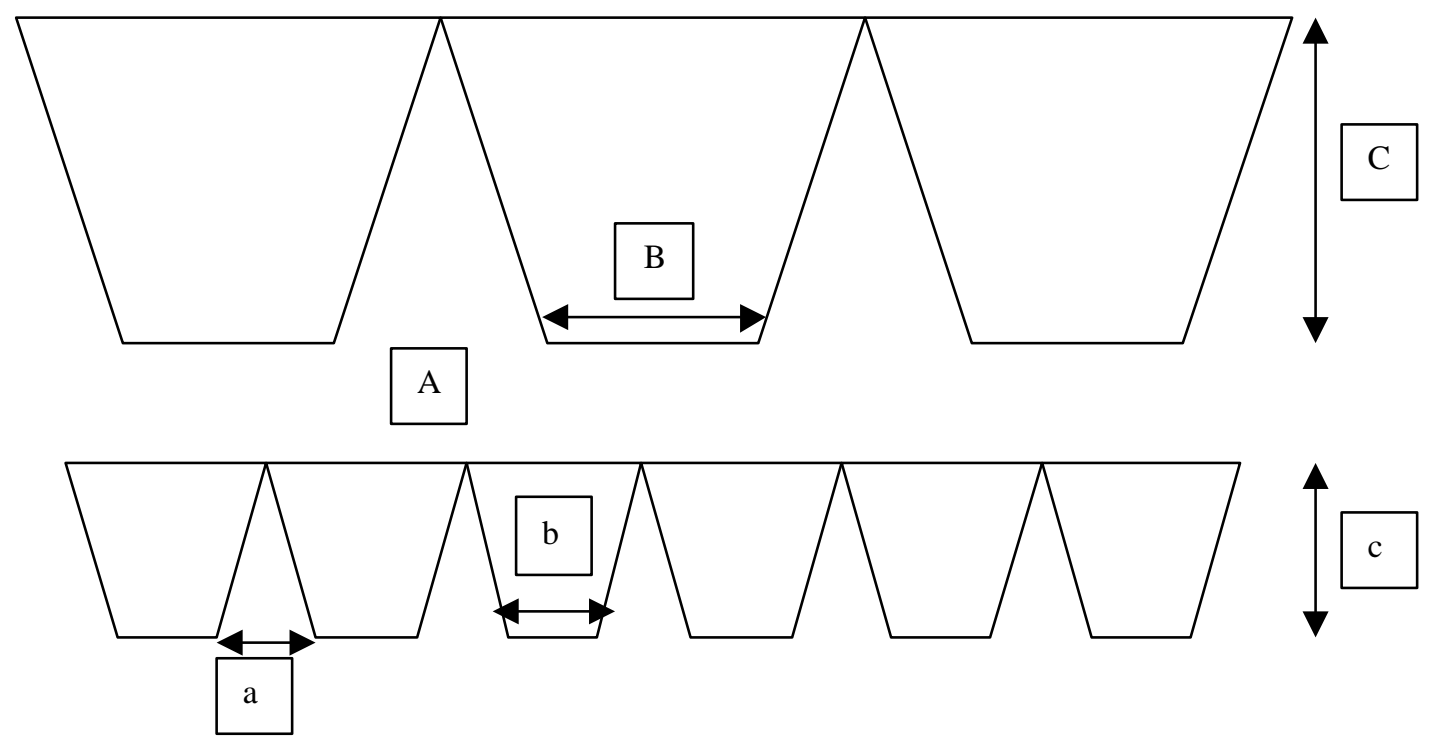

Figura 23 - Formato e distribuição das touceiras na pastagem em função da intensidade de pastejo. As letras a, b e c representam a distância entre touceiras, diâmetro da área basal da touceira e altura da planta. O desenho com letras maiúsculas representa a pastagens com menor intensidade de pastejo. 
Através dessa hipótese é possível avaliar o manejo das pastagens em função do RC (cm de altura) da planta, do espaçamento entre as touceiras e do diâmetro da área basal da touceira através do seguinte modelo:

$R C=\{\operatorname{tg} a[(D / 2)+(s(D+d) / 100)]\} / n$ (modelo 1$)$

Onde:

$\mathrm{H}=$ ritmo de crescimento $(\mathrm{cm} / \mathrm{dia})$;

$a=$ angulo de inclinação da touceira em relação ao solo $\left({ }^{\circ}\right)$;

$\mathrm{D}=$ distância entre touceiras $(\mathrm{cm})$;

$\mathrm{d}=$ diâmetro da área basal da touceira $(\mathrm{cm})$;

$\mathrm{S}=$ sobreposição entre as folhas das touceiras vizinhas em função da diâmetro superior da touceira (\%);

$\mathrm{S}=$ Diâmetro da área de sombreamento da touceira $(\mathrm{cm})$

$\mathrm{n}=$ número de dias para ocorrer o sombreamento com a sobreposição (dias).

O modelo foi desenvolvido aplicando conceitos de trigonometria sobre a Figura 24 a partir da equação:

$R C=\operatorname{tg} a[(D / 2)+s S]$ onde $S=d+(2 D / 2)=d+D$

Esse modelo também leva em consideração a taxa de sobreposição (s) entre as folhas das touceiras vizinhas e o tempo necessário para ocorrer essa sobreposição ( $\mathrm{t}$ ). Essas considerações são importantes quando avaliamos a capacidade da planta em competir por luz com outras plantas (daninhas ou não). 


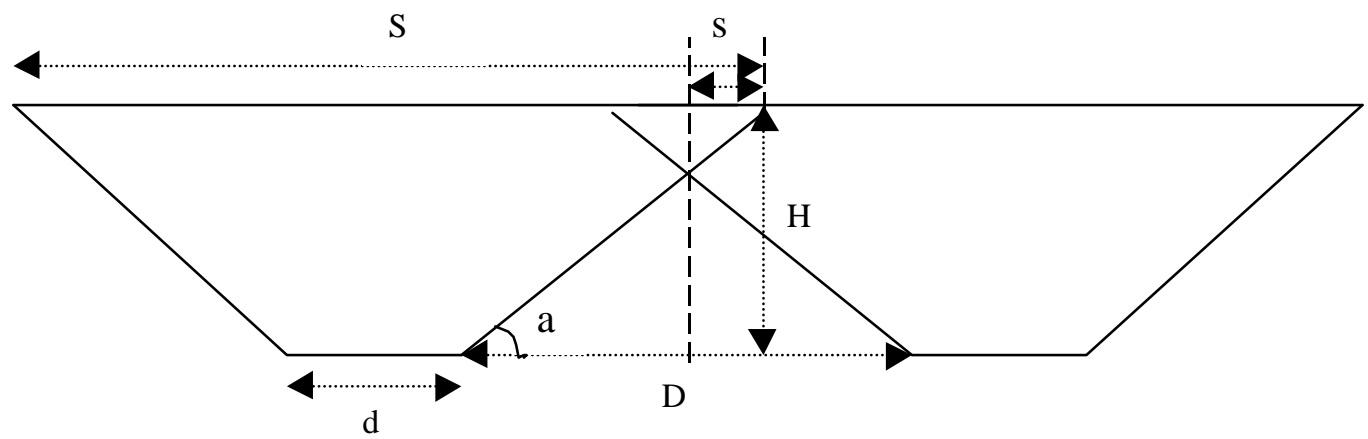

Figura 24 - Croqui de touceiras vizinhas com suas folhas em sobreposição. $\mathrm{H}=$ altura $(\mathrm{cm}) ; \mathrm{a}=$ angulo de inclinação da touceira ( $)$; D = distância entre touceiras $(\mathrm{cm}) ; \mathrm{d}=$ diâmetro da área basal da touceira $(\mathrm{cm}) ; \mathrm{S}$ $=$ diâmetro da área de sombreamento da touceira $(\mathrm{cm}) ; \mathrm{s}=$ sobreposição entre as folhas das touceiras vizinhas em função de $S$ (\%).

Através desse modelo será possível determinar o ritmo de crescimento da planta necessário para que, em um determinado intervalo de tempo e taxa de sobreposição, a planta seja capaz de cobrir a área do solo sem touceira. $\mathrm{Na}$ Tabela 27 temos vários exemplos de ritmos de crescimentos gerados pelo modelo.

No primeiro exemplo da Tabela 27, a planta devera crescer $2,4 \mathrm{~cm} /$ dia para manter-se estabelecida na área entretanto, se o $\mathrm{RC}$ for inferior a 2,4 cm/dia, alterações no manejo devem ser realizadas, como por exemplo aumentar o nível de adubação e/ou aumentar a altura de pastejo. Pelo modelo podemos justificar os resultados positivos na recuperação da pastagem com 0 aumento na altura de pastejo pois além de manter uma área foliar remanescente maior ou seja, melhorar a capacidade de rebrota da planta, o aumento na altura de pastejo reduz a distância $(\mathrm{H})$ entre a altura de pastejo e a altura necessária para ocorrer o sombreamento total da área (Figura 25). Dessa 
forma, o ritmo de crescimento da planta poderá ser menor para sombrear a área no mesmo intervalo de tempo.

Tabela 27. Ritmo de crescimento da planta necessário para ocorrer a sobreposição de $10 \%$ das folhas das touceiras vizinhas em 20 dias a pós o corte ou pastejo seguindo o modelo 1.

\begin{tabular}{|c|c|c|c|c|c|}
\hline \multirow[t]{3}{*}{ Parâmetros } & \multicolumn{5}{|c|}{ Valores } \\
\hline & \multicolumn{5}{|c|}{ A - Variando a distância entre touceiras vizinhas } \\
\hline & 20 & 20 & 20 & 20 & 20 \\
\hline $\mathrm{d}(\mathrm{cm})$ & 40 & 40 & 40 & 40 & 40 \\
\hline $\mathrm{D}(\mathrm{cm})$ & 40 & 50 & 60 & 70 & 80 \\
\hline $\mathrm{s}(\%)$ & 10 & 10 & 10 & 10 & 10 \\
\hline$a\left({ }^{\circ}\right)$ & 60 & 60 & 60 & 60 & 60 \\
\hline $\mathrm{H}(\mathrm{cm})$ & 48 & 59 & 69 & 80 & 90 \\
\hline \multirow[t]{2}{*}{$\mathrm{RC}(\mathrm{cm} / \mathrm{dia})$} & 2,4 & 2,9 & 3,5 & 4,0 & 4,5 \\
\hline & \multicolumn{5}{|c|}{ B - Variando o diâmetro da área basal da touceira } \\
\hline $\mathrm{n}$ (dias) & 20 & 20 & 20 & 20 & 20 \\
\hline $\mathrm{d}(\mathrm{cm})$ & 20 & 30 & 40 & 50 & 60 \\
\hline $\mathrm{D}(\mathrm{cm})$ & 60 & 60 & 60 & 60 & 60 \\
\hline $\mathrm{s}(\%)$ & 10 & 10 & 10 & 10 & 10 \\
\hline$a\left({ }^{\circ}\right)^{\prime}$ & 60 & 60 & 60 & 60 & 60 \\
\hline $\mathrm{H}(\mathrm{cm})$ & 66 & 68 & 69 & 71 & 73 \\
\hline \multirow[t]{2}{*}{$\mathrm{RC}(\mathrm{cm} / \mathrm{dia})$} & 3,3 & 3,4 & 3,5 & 3,6 & 3,6 \\
\hline & \multicolumn{5}{|c|}{ C - Variando o angulo de inclinação da touceira } \\
\hline n (dias) & 20 & 20 & 20 & 20 & 20 \\
\hline $\mathrm{d}(\mathrm{cm})$ & 40 & 40 & 40 & 40 & 40 \\
\hline $\mathrm{D}(\mathrm{cm})$ & 60 & 60 & 60 & 60 & 60 \\
\hline $\mathrm{s}(\%)$ & 10 & 10 & 10 & 10 & 10 \\
\hline$a\left({ }^{\circ}\right)$ & 40 & 50 & 60 & 70 & 80 \\
\hline $\mathrm{H}(\mathrm{cm})$ & 34 & 48 & 69 & 110 & 227 \\
\hline $\mathrm{RC}(\mathrm{cm} / \mathrm{dia})$ & 1,7 & 2,4 & 3,5 & 5,5 & 11,3 \\
\hline
\end{tabular}




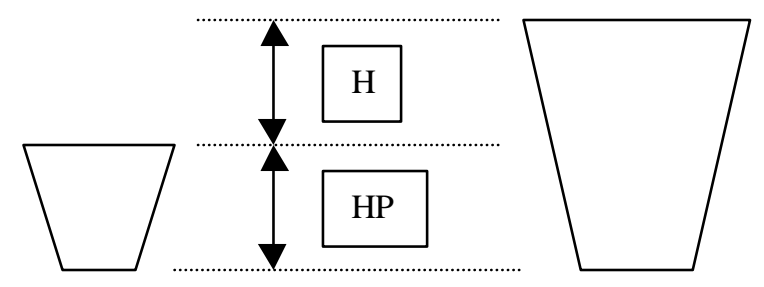

Figura 25 - Redução da altura $(H)$ necessária para ocorrer o sombreamento em função do aumento na altura de pastejo (HP).

Pela Tabela 27 podemos observar que o angulo de inclinação dos perfilhos externos da touceira (a) tem forte influência sobre o RC ou seja, quanto menor a inclinação da touceira menor é o $\mathrm{RC}$ da planta para sombrear o solo descoberto. Alterações no angulo e no formato da planta podem ocorrer como mecanismos de adaptação da planta a mudanças no manejo. Entretanto, nesse trabalho não houve alteração no angulo $\left(57^{\circ}\right.$ e $57^{\circ}$ para os $\mathrm{T} 1$ e T3 antes do pastejo, respectivamente e $56^{\circ}$ e $63^{\circ}$ para T1 e T3 após o primeiro dia de pastejo, respectivamente) (Figuras 14 e 15, respectivamente) e no formato das touceiras em função do nível de MFVR conforme observa-se na Figura 26. Esses resultados indicam que essas características podem ser pouco influenciadas pelo meio ambiente. Portanto essas característica morfológica da planta deveriam merecer atenção nos programas de seleção e melhoramento de cultivares de Panicum sp. ou de outras espécies que formam touceiras para serem utilizadas como ferramentas para o manejo das plantas forrageiras para corte e/ou pastejo. 


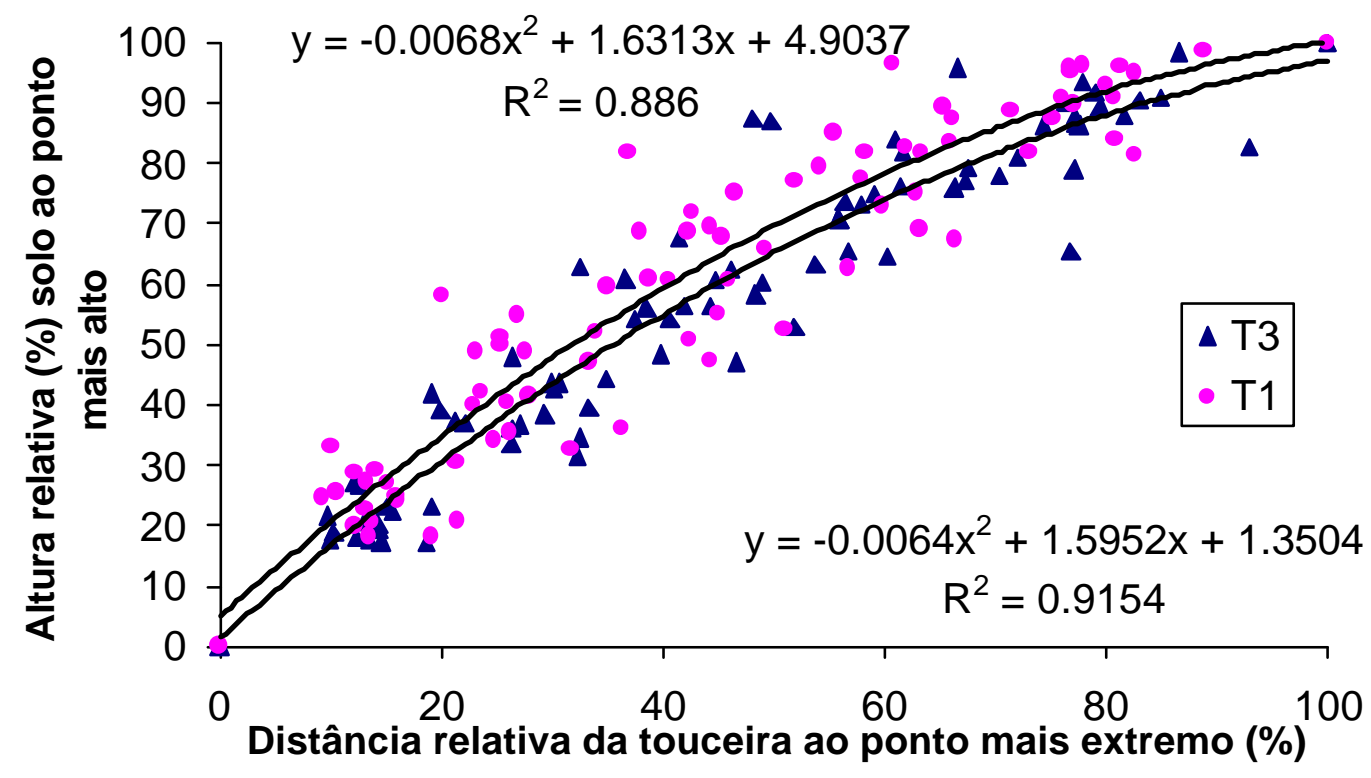

Figura 26 - Formato externo das touceiras representado pelas equações quadráticas. Não houve diferença entre as equações a $p<0.05$. O perímetro da touceira e o solo foram definidos como $0 \%$ enquanto que os pontos mais altos do solo e distantes da touceira foram definidos como $100 \%$.

O diâmetro da touceira $(20$ a $60 \mathrm{~cm}$ ) (d) tem pouca influência sobre 0 processo de sombreamento como observa-se na Tabela 27. Desse modo o modelo 1 poderia ser substituído por um modelo mais simples (modelo 2). Esse novo modelo, também foi desenvolvido através de conceitos de trigonometria aplicados sobre a Figura 24, entretanto ele não considera o diâmetro da touceira e a taxa de sombreamento é expressa em função da distância entre as touceiras (D) e não do diâmetro superior das touceiras (S) como foi feito para o modelo 1.

Quando comparamos os resultados estimados pelos modelos 1 e 2 (Tabela 27 e 28, respectivamente) verificamos que eles são semelhantes e dessa forma, o modelo 2 seria mais indicado pois para usa-lo não é necessário medir o diâmetro da touceira. Além disso, se o angulo da touceira não for 
alterado pelo meio ambiente esse valor poderá ser tabelado futuramente e dessa forma a única medida a ser determinada no campo para utilizar o modelo 2 será a distância entre touceiras vizinhas.

$\mathrm{RC}=\{\operatorname{tg} \mathrm{a}[(\mathrm{D} / 2)+(\mathrm{s}(\mathrm{D}) / 100)]\} / \mathrm{n}$ (modelo 2$)$

Tabela 28. Ritmo de crescimento da planta necessário para ocorrer a sobreposição de $10 \%$ das folhas das touceiras vizinhas em 20 dias seguindo o modelo 2 .

\begin{tabular}{ll}
\hline Parâmetros & Valores
\end{tabular}

\begin{tabular}{|c|c|c|c|c|c|}
\hline \multirow[b]{2}{*}{ n (dias) } & \multicolumn{5}{|c|}{ A - Variando a distância entre touceiras vizinhas } \\
\hline & 20 & 20 & 20 & 20 & 20 \\
\hline $\mathrm{d}(\mathrm{cm})$ & 40 & 40 & 40 & 40 & 40 \\
\hline $\mathrm{D}(\mathrm{cm})$ & 40 & 50 & 60 & 70 & 80 \\
\hline $\mathrm{s}(\%)$ & 10 & 10 & 10 & 10 & 10 \\
\hline$a\left(^{\circ}\right)^{\prime}$ & 60 & 60 & 60 & 60 & 60 \\
\hline $\mathrm{H}(\mathrm{cm})$ & 42 & 52 & 62 & 73 & 83 \\
\hline \multirow[t]{2}{*}{$\mathrm{RC}(\mathrm{cm} / \mathrm{dia})$} & 2,1 & 2,6 & 3,1 & 3,6 & 4,2 \\
\hline & \multicolumn{5}{|c|}{ B - Variando o angulo de inclinação da touceira } \\
\hline n (dias) & 20 & 20 & 20 & 20 & 20 \\
\hline $\mathrm{d}(\mathrm{cm})$ & 40 & 40 & 40 & 40 & 40 \\
\hline $\mathrm{D}(\mathrm{cm})$ & 60 & 60 & 60 & 60 & 60 \\
\hline $\mathrm{s}(\%)$ & 10 & 10 & 10 & 10 & 10 \\
\hline$a\left(^{0}\right)^{\prime}$ & 40 & 50 & 60 & 70 & 80 \\
\hline $\mathrm{H}(\mathrm{cm})$ & 30 & 43 & 62 & 99 & 204 \\
\hline $\mathrm{RC}(\mathrm{cm} / \mathrm{dia})$ & 1,5 & 2,1 & 3,1 & 4,9 & 10,2 \\
\hline
\end{tabular}




\subsection{Produção de forragem e desempenho animal}

Pela Tabela 29 podemos observar que o aumento na MFVR proporcionou incrementos positivos na produção total de matéria seca (PTMSP) e na produção total da matéria seca verde (PTMVP) nas pastagens.

Tabela 29. Resultados das análises estatísticas de algumas variáveis relacionadas a produção animal e vegetal sobre o efeito dos tratamentos durante período de 30/10/99 a 3/01/01.

\begin{tabular}{|c|c|c|c|}
\hline Parâmetro & $\begin{array}{l}\text { Valor } \\
\text { médio }\end{array}$ & $\begin{array}{l}\text { Análise }^{1} \\
\text { estatística }\end{array}$ & $\begin{array}{l}\text { Trata- } \\
\text { mento }\end{array}$ \\
\hline $\begin{array}{l}1 \text { - Produção total de matéria seca (kg/ha) } \\
\text { Antes do pastejo - (PTMSP) }\end{array}$ & $\begin{array}{l}90.255 \\
77.396 \\
47.135\end{array}$ & $\begin{array}{l}A \\
B \\
C\end{array}$ & $\begin{array}{l}3 \\
2 \\
1\end{array}$ \\
\hline $\begin{array}{l}2 \text { - Produção total de matéria seca verde }(\mathrm{kg} / \mathrm{ha}) \\
\text { Antes do pastejo - (PTMVP) }\end{array}$ & $\begin{array}{l}68.233 \\
56.221 \\
35.354\end{array}$ & $\begin{array}{l}A \\
B \\
C\end{array}$ & $\begin{array}{l}3 \\
2 \\
1\end{array}$ \\
\hline $\begin{array}{l}3 \text { - Produção total acumulada de matéria seca } \\
\text { (kg/ha) (PTAMS) }\end{array}$ & $\begin{array}{l}36.850 \\
34.144 \\
25.278\end{array}$ & $\begin{array}{l}A \\
A \\
B\end{array}$ & $\begin{array}{l}2 \\
3 \\
1\end{array}$ \\
\hline $\begin{array}{l}4 \text { - Produção total acumulada de matéria seca } \\
\text { verde (kg/ha) - (PTAMV) }\end{array}$ & $\begin{array}{l}27.049 \\
25.333 \\
21.406\end{array}$ & $\begin{array}{l}A \\
A \\
B\end{array}$ & $\begin{array}{l}2 \\
3 \\
1\end{array}$ \\
\hline $\begin{array}{l}5 \text { - Produção total de haste (kg MS ou MSV/ha) } \\
\text { (PTH) }\end{array}$ & $\begin{array}{l}36.839 \\
28.028 \\
15.015\end{array}$ & $\begin{array}{l}A \\
B \\
C\end{array}$ & $\begin{array}{l}3 \\
2 \\
1\end{array}$ \\
\hline $\begin{array}{l}6 \text { - Produção total acumulada de haste }{ }^{2} \\
\text { (kg MS ou MSV/ha) - (PTAH) }\end{array}$ & $\begin{array}{l}6.457 \\
4.928 \\
4.070\end{array}$ & $\begin{array}{c}A \\
A B \\
B\end{array}$ & $\begin{array}{l}2 \\
3 \\
1\end{array}$ \\
\hline $\begin{array}{l}7 \text { - Produção total de folhas (kg MS ou MSV/ha) } \\
\text { (PTF) }\end{array}$ & $\begin{array}{l}31.394 \\
28.182 \\
20.339\end{array}$ & $\begin{array}{l}A \\
A \\
B\end{array}$ & $\begin{array}{l}3 \\
2 \\
1\end{array}$ \\
\hline
\end{tabular}


Tabela 29. Resultados das análises estatísticas de algumas variáveis relacionadas a produção animal e vegetal sobre o efeito dos tratamentos durante período de 30/10/99 a 3/01/01.

\begin{tabular}{|c|c|c|c|}
\hline Parâmetro & $\begin{array}{l}\text { Valor } \\
\text { médio }\end{array}$ & $\begin{array}{l}\text { Análise }^{1} \\
\text { estatística }\end{array}$ & $\begin{array}{l}\text { Trata- } \\
\text { mento }\end{array}$ \\
\hline $\begin{array}{l}8 \text { - Produção total acumulada de folhas } \\
\text { (kg MS ou MSV/ha) - (PTAF) }\end{array}$ & $\begin{array}{l}20.592 \\
20.416 \\
17.336\end{array}$ & $\begin{array}{l}A \\
A \\
A\end{array}$ & $\begin{array}{l}2 \\
3 \\
1\end{array}$ \\
\hline $\begin{array}{l}9 \text { - Produção total de material morto (kg MS/ha) } \\
\text { (PTMM) }\end{array}$ & $\begin{array}{l}22.363 \\
21.175 \\
11.561\end{array}$ & $\begin{array}{l}\text { A } \\
A \\
B\end{array}$ & $\begin{array}{l}3 \\
2 \\
1\end{array}$ \\
\hline $\begin{array}{l}10 \text { - Produção total acumulada de material morto } \\
\text { (kg MS/ha) - (PTAMM) }\end{array}$ & $\begin{array}{l}9.801 \\
8.646 \\
3.663\end{array}$ & $\begin{array}{c}A \\
A B \\
A\end{array}$ & $\begin{array}{l}2 \\
3 \\
1\end{array}$ \\
\hline 11 - Lotação animal média (UA/ha) - (LAM) & $\begin{array}{l}6,5 \\
5,2 \\
4,1\end{array}$ & $\begin{array}{l}\text { A } \\
B \\
\text { C }\end{array}$ & $\begin{array}{l}1 \\
2 \\
3\end{array}$ \\
\hline $\begin{array}{l}12 \text { - Produtividade total (kg de peso vivo/ha) } \\
\text { ajustando o número de cabeças em função } \\
\text { do PV dos testers - (PROTO) }\end{array}$ & $\begin{array}{l}1.518 \\
1.419 \\
1.287\end{array}$ & $\begin{array}{l}\text { A } \\
A \\
A\end{array}$ & $\begin{array}{l}1 \\
2 \\
3\end{array}$ \\
\hline 13 - Eficiência de pastejo (\%) (EP) & $\begin{array}{l}75 \\
67 \\
47\end{array}$ & $\begin{array}{l}A \\
A \\
B\end{array}$ & $\begin{array}{l}1 \\
2 \\
3\end{array}$ \\
\hline $\begin{array}{l}14 \text { - Ganho de peso vivo médio (g/cab/dia) } \\
\text { (GPV) }\end{array}$ & $\begin{array}{l}398 \\
541 \\
564\end{array}$ & $\begin{array}{l}\text { A } \\
B \\
B\end{array}$ & $\begin{array}{l}1 \\
2 \\
3\end{array}$ \\
\hline $\begin{array}{l}15 \text { - Produção total de matéria seca verde } \\
\text { (kg/ha) pós do pastejo (MFVRT) }\end{array}$ & $\begin{array}{l}46.816 \\
32.065 \\
13.926\end{array}$ & $\begin{array}{l}\text { A } \\
B \\
C\end{array}$ & $\begin{array}{l}3 \\
2 \\
1\end{array}$ \\
\hline $\begin{array}{l}16 \text { - Produção média de matéria seca verde } \\
\text { (kg/ha/ciclo) pós pastejo - (MFVR) }\end{array}$ & $\begin{array}{l}4.256 \\
2.915 \\
1.266\end{array}$ & $\begin{array}{l}\text { A } \\
B \\
C\end{array}$ & $\begin{array}{l}3 \\
2 \\
1\end{array}$ \\
\hline $\begin{array}{l}17 \text { - Peso vivo dos animais testers no final } \\
\text { Do experimento }(\mathrm{kg}) \text { - (PV) }\end{array}$ & $\begin{array}{l}384 \\
446 \\
444\end{array}$ & $\begin{array}{l}\text { A } \\
B \\
B\end{array}$ & $\begin{array}{l}1 \\
2 \\
3\end{array}$ \\
\hline
\end{tabular}


Resultado semelhante foi obtido na avaliação do efeito dos tratamentos sobre a produção de matéria seca (PMSP) e produção de matéria seca verde (PMVP) dentro de cada época de pastejo (Tabelas 30 e 31, respectivamente).

Tabela 30. Produção média de matéria seca antes dos pastejos (PMSP) em função dos tratamentos e das épocas do ano ${ }^{1}$.

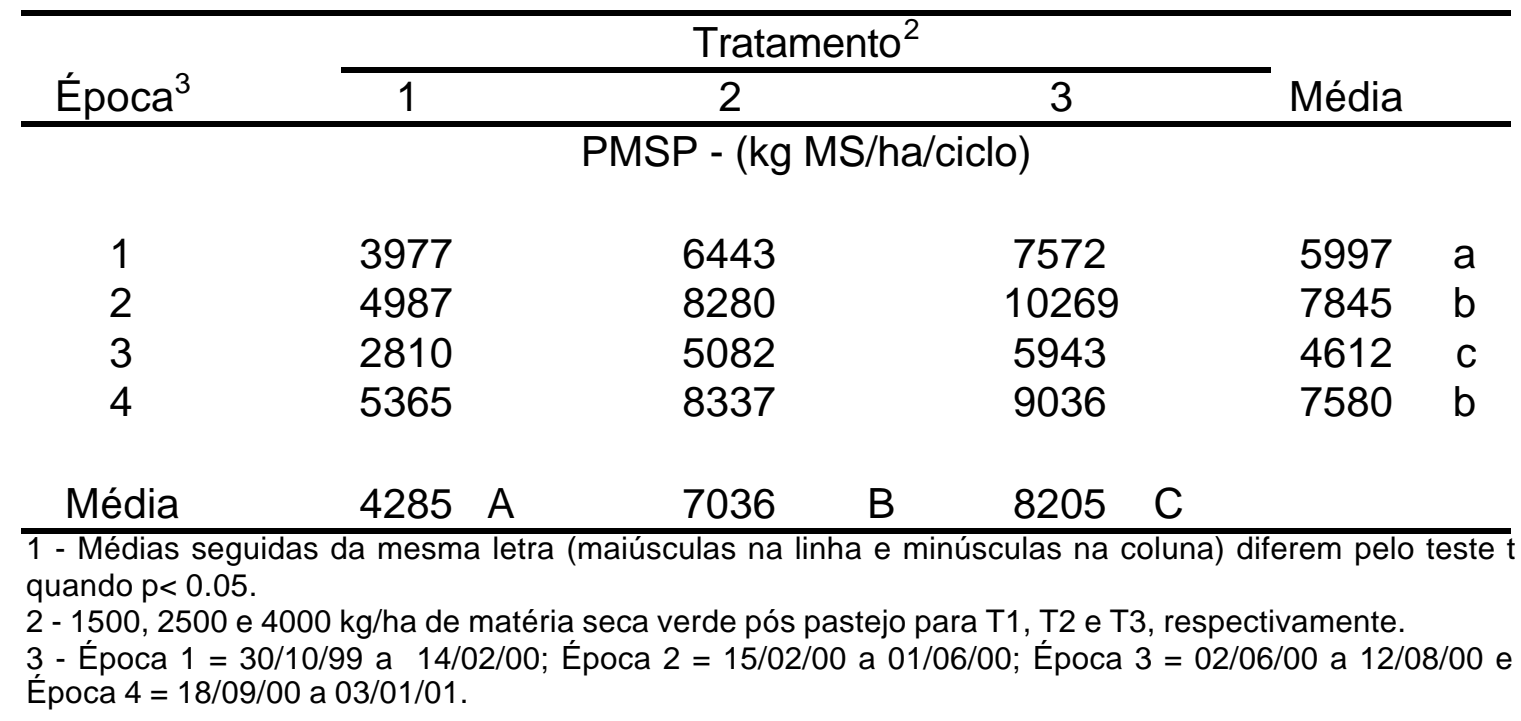

Tabela 31. Produção média de matéria seca verde antes dos pastejos (PMVP) em função dos tratamentos e das épocas do ano ${ }^{1}$.

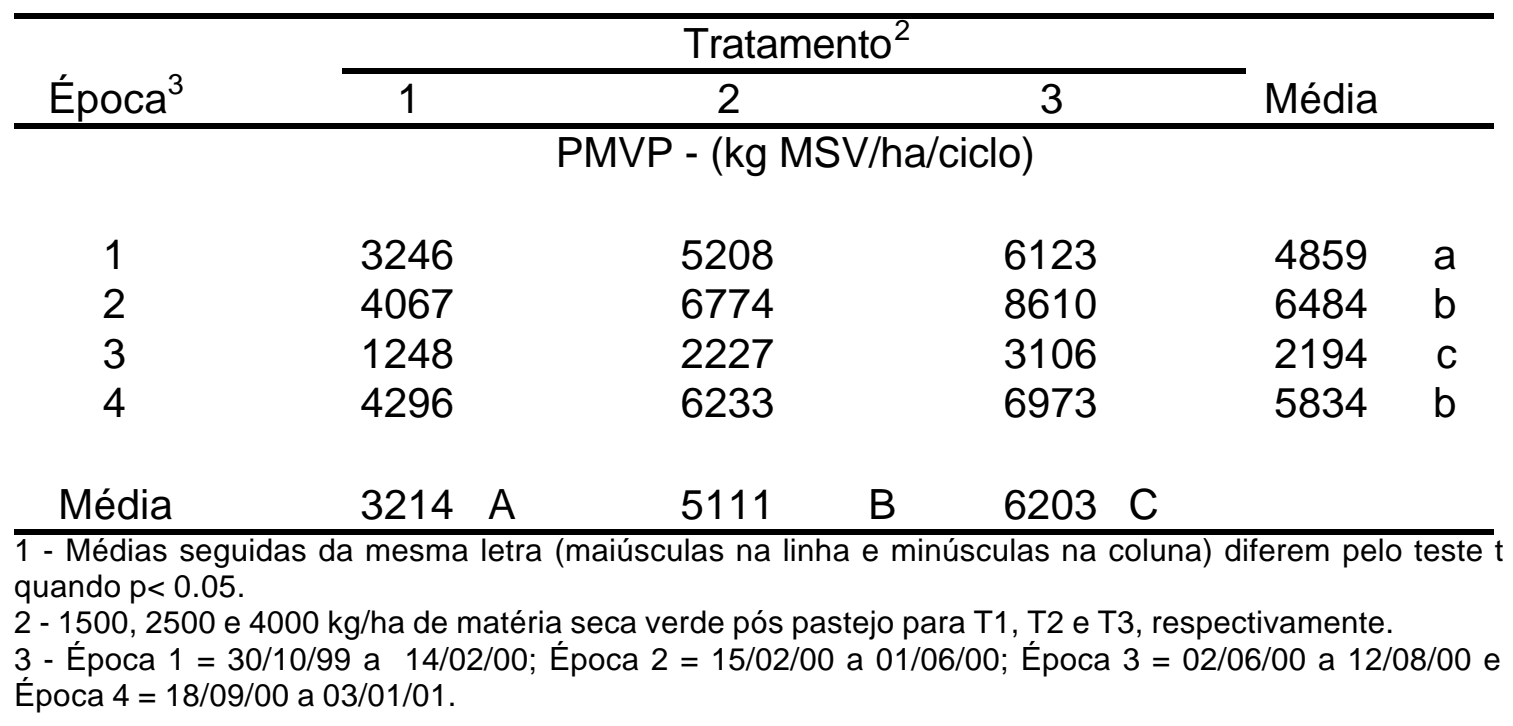


As PMSP e PMVP oscilaram durante 0 período experimental, evidenciando o processo da estacionalidade da produção de forragem. As PMSP e PMVP aumentaram da época 1 para a época 2 e depois a produção voltou a cair para então, na época 4 , voltar a crescer. O aumento da produção de forragem na época 2 esta associado ao incremento na produção de haste (Tabela 17) devido ao florescimento do capim. A produção de forragem na época 3 foi limitada pelas condições climáticas visto que nesta época do ano foram registradas as menores temperaturas e radiação solar do período experimental (Tabela 1).

Além disso, na época 3, a rebrota do capim e o consumo de forragem foram limitados pelo aumento na taxa de acúmulo de material morto (MMAC) (Tabela 32) causado pelo intenso processo de senescência dos perfilhos que morreram após o florescimento.

Tabela 32. Taxa média de acúmulo de material morto antes dos pastejos (MMAC) em função dos tratamentos e das épocas do ano 1 .

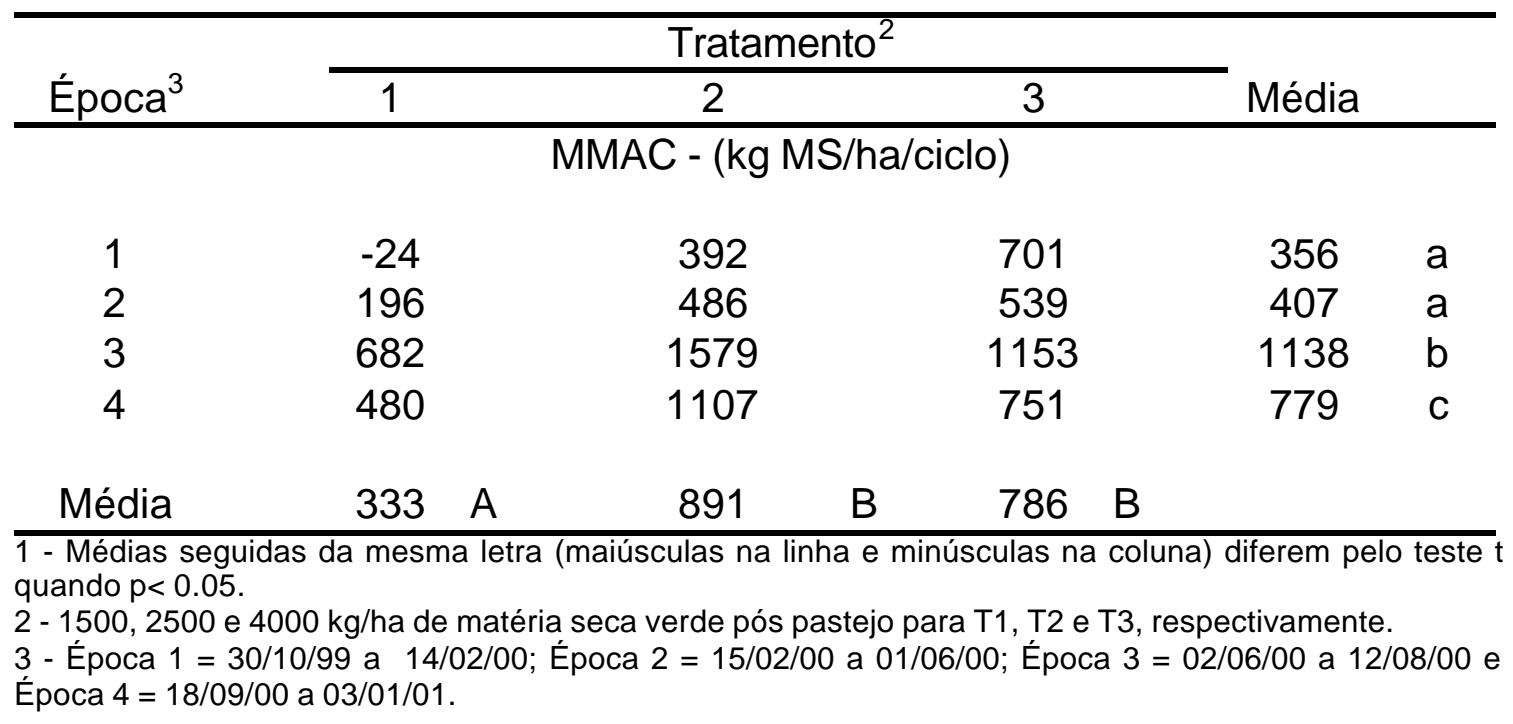

Os valores negativos das taxas de acumulo de matéria seca (ACMS) e taxas de acúmulo de matéria seca verde (ACMV) na época 3 (Tabelas 33 e 34, respectivamente) pode ser explicados pelas razões já apresentadas no 
parágrafo acima. Porém essas variáveis não diferiram entre as épocas 1, 2 e 4 . Esse fato indica que a ACMV e ACMS apresentaram menores variações que a PMSP e PMVP.

Tabela 33. Taxa média de acúmulo de matéria seca antes dos pastejos (ACMS) em função dos tratamentos e das épocas do ano ${ }^{1}$.

\begin{tabular}{|c|c|c|c|c|c|c|c|c|c|c|}
\hline \multirow[b]{2}{*}{ Época $^{3}$} & \multicolumn{9}{|c|}{ Tratamento $^{2}$} & \multirow[b]{2}{*}{ Média } \\
\hline & \multicolumn{2}{|l|}{1} & & \multicolumn{2}{|c|}{2} & & \multicolumn{2}{|l|}{3} & & \\
\hline \multicolumn{11}{|c|}{ ACMS - (kg MS/ha/ciclo) } \\
\hline 1 & 2316 & A & a & 3907 & B & a & 4709 & B & a & 3644 \\
\hline 2 & 2796 & A & a & 4231 & $A B$ & a & 4645 & B & a & 3891 \\
\hline 3 & 579 & $A B$ & b & 638 & B & b & -556 & A & b & 221 \\
\hline 4 & 3502 & A & a & 4625 & A & $\mathrm{a}$ & 3618 & A & a & 3915 \\
\hline Média & 2298 & & & 3350 & & & 3104 & & & \\
\hline $\begin{array}{l}1-\text { Médias } \\
\text { quando p< } \\
2-1500,2 \\
3-\text { Época } \\
\text { Época } 4=\end{array}$ & $3 / 01$ & . & & 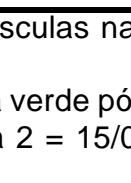 & & & las nac & & & $\begin{array}{l}\text { ste } t \\
00 \mathrm{e}\end{array}$ \\
\hline
\end{tabular}

Tabela 34. Taxa média de acúmulo de matéria seca verde antes dos pastejos (ACMV) em função dos tratamentos e das épocas do ano ${ }^{1}$.

\begin{tabular}{|c|c|c|c|c|c|c|c|c|c|c|}
\hline \multirow[b]{2}{*}{ Época $^{3}$} & \multicolumn{9}{|c|}{ Tratamento $^{2}$} & \multirow[b]{2}{*}{ Média } \\
\hline & 1 & & & 2 & & & 3 & & & \\
\hline \multicolumn{11}{|c|}{ ACMV- (kg MSV/ha/ciclo) } \\
\hline 1 & 2341 & A & a & 3515 & $A B$ & a & 4008 & B & a & 3288 \\
\hline 2 & 2600 & A & a & 3745 & A & a & 4106 & A & a & 3484 \\
\hline 3 & -180 & B & b & -942 & $A B$ & b & -1618 & B & b & -913 \\
\hline 4 & 3022 & A & A & 3518 & A & a & 2719 & A & a & 3086 \\
\hline Média & 1946 & & & 2459 & & & 2303 & & & \\
\hline $\begin{array}{l}1 \text { - Médias } \\
\text { quando p< } \\
2-1500,2 \\
3-\text { Época } \\
\text { Época } 4=\end{array}$ & da mes & 1. & & & & & culas na & & & $\begin{array}{l}0 \text { teste } \mathrm{t} \\
\text { j08/00 e }\end{array}$ \\
\hline
\end{tabular}


A estacionalidade na produção de forragem também foi observada nos trabalhos de Teixeira (1998) e Tosi (1999). Entretanto, nenhum dos autores determinaram valores negativos para taxa de acúmulo. Além disso, a taxa média de acúmulo de MS determinada por Teixeira (1998) (256 kg MS/ha/dia) foi 1,8 vezes superior a melhor taxa de acumulo determinada neste experimento $(143 \mathrm{~kg} \mathrm{MS} / \mathrm{ha} / \mathrm{dia}=4709 \mathrm{~kg} \mathrm{MS} / \mathrm{ha}$ dividido por 33 dias de descanso - Tabela 33) porém, esse valor esta próximos dos resultados determinados por Tosi (1999) de $139 \mathrm{~kg} \mathrm{MS/ha/dia} \mathrm{como} \mathrm{média} \mathrm{do} \mathrm{período} \mathrm{de} \mathrm{"verão".} \mathrm{As} \mathrm{taxas} \mathrm{mais}$ baixas de acúmulo determinadas nesse experimento em relação as de Teixeira (1998) pode estar associada ao fato das pastagens serem novas e não houve tempo suficiente para sua estabilização. Essa hipótese é suportada pela queda na TO, conforme discutido no item 4.3. e pelos dados de Maia (2002) ${ }^{1}$ (informação pessoal) de que as produções de forragem na mesma área experimental estão superiores as produções determinadas nesse experimento.

${ }^{1}$ Mesmo não determinando diferenças na ACMS e ACMV entre ${ }^{2}$ os tratamentos nas épocas 2 e 4, foi observado que a somatória das produções acumuladas de matéria seca (PTAMS) e a somatória das produções acumuladas de matéria seca verde (PTAMV) no final do experimento foram iguais entre os T2 e T3 mas superiores ao T1. Nesse caso o aumento de MFVR a partir dos níveis obtidos para o T2 (2915 kg/ha de MSV no resíduo) não acarretará em incrementos significativos na PTAMS e PTAMV assim como na produção total acumulada de de haste (PTAH), produção total de folhas (PTF), produção total de material morto (PTMM) e produção total acumulada de material morto (PTAMM) (Tabela 29). Entretanto o aumento na MFVR aumentou a PTH mas não houve efeito dos tratamentos sobre a produção total acumulada de folhas (PTAF) (Tabela 29).

Apesar das PTMSP e PTMVP aumentarem com a MFVR, a lotação animal média (LAM) do período experimental diminuiu com o aumento da

1 - Maia, F.L.A. (2002) - Dados do trabalho de Dissertação que esta sendo realizado na ESALQ 
MFVR (Tabela 29). Quando avaliamos a lotação animal (LA) dentro de cada época observamos (Tabela 35) que, com exceção da época 1, os resultado foram semelhante a LAM.

Tabela 35. Taxa média de lotação animal (LA) em função dos tratamentos e das épocas do ano ${ }^{1}$.

\begin{tabular}{llll}
\hline & \multicolumn{3}{c}{ Tratamento $^{2}$} \\
Época $^{3}$ & 1 & 3 & Média \\
\hline \multicolumn{3}{c}{ LA (UA/ha) } &
\end{tabular}

$\begin{array}{lllllllllll}1 & 6,3 & \text { A } & \text { a } & 5,4 & \text { AB } & \text { a } & 4,5 & \text { B } & \text { ab } & 5,4 \\ 2 & 5,8 & \text { A } & \text { a } & 4,9 & \text { B } & \text { a } & 4,1 & \text { C } & \text { a } & 4,9 \\ 3 & 4,8 & \text { A } & \text { b } & 3,7 & \text { B } & \text { b } & 2,7 & \text { C } & \text { c } & 3,7 \\ 4 & 9,2 & \text { A } & \text { C } & 6,7 & \text { B } & \text { c } & 5,2 & \text { C } & \text { b } & 7,0\end{array}$

$\begin{array}{lrrr}\text { Média } & 6,5 & 5,2 & 4,1\end{array}$

1 - Médias seguidas da mesma letra (maiúsculas na linha e minúsculas na coluna) diferem pelo teste $t$ quando $\mathrm{p}<0.05$.

2 - 1500, 2500 e $4000 \mathrm{~kg} / \mathrm{h}$ a de matéria seca verde pós pastejo para T1, T2 e T3, respectivamente.

3 - Época 1 = 30/10/99 a 14/02/00; Época $2=15 / 02 / 00$ a 01/06/00; Época $3=02 / 06 / 00$ a 12/08/00 e Época $4=18 / 09 / 00$ a 03/01/01.

Diferenças entre as LA também ocorreram entre as épocas de pastejo. A LA na época 4 foi superior as demais épocas enquanto que as épocas 1 e 2 foram superiores a época 3. As menores lotações determinadas na época 3 deve-se ao fato das menores produções de forragem ocorrerem nessa época (Tabelas 30 e 31). Entretanto esse mesmo argumento não pode explicar o fato da lotação na época 4 ser maior que na época 2 visto que, nessas épocas, as produções de forragem foram semelhantes. A provável explicação para o fato deve estar associada aos processos de perdas de forragem pela ação física dos animais. Tomando como referência os resultados das Tabelas 36 e 37 não poderíamos justificar a diferença entre as lotações pelos processos de perdas pois não houve diferenças entre as épocas 2 e 4 com relação a porcentagem de perdas (PER\%) e quantidade de forragem perdida por unidade de área 
(PERHA), respectivamente. Deve-se salientar que as PER\% não diferiram entre os tratamentos e épocas entretanto a eficiência de pastejo foi menor no T3 mas semelhantes entre o T1 e T2 (Tabela 29).

Tabela 36. Perdas de forragem relativas a produção de forragem (PER\%) em função dos tratamentos e das épocas do ano ${ }^{1}$.

\begin{tabular}{cccccc}
\hline & \multicolumn{4}{c}{ Tratamento $^{2}$} & \\
\cline { 2 - 4 } Época $^{3}$ & 1 & 2 & 3 & Média \\
\hline & & PER\% & & & \\
1 & $17 \%$ & $19 \%$ & $27 \%$ & $21 \%$ & a \\
2 & $14 \%$ & $17 \%$ & $22 \%$ & $18 \%$ & a \\
3 & $17 \%$ & $14 \%$ & $16 \%$ & $16 \%$ & a \\
4 & $15 \%$ & $17 \%$ & $21 \%$ & $18 \%$ & a
\end{tabular}

$\begin{array}{lllllll}\text { Média } & 16 \% & \mathrm{~A} & 17 \% & \mathrm{~A} & 22 \% & \mathrm{~A}\end{array}$

1 - Médias seguidas da mesma letra (maiúsculas na linha e minúsculas na coluna) diferem pelo teste $t$ quando $\mathrm{p}<0.05$.

2 - 1500, 2500 e $4000 \mathrm{~kg} / \mathrm{h}$ a de matéria seca verde pós pastejo para T1, T2 e T3, respectivamente.

3 - Época $1=30 / 10 / 99$ a 14/02/00; Época $2=15 / 02 / 00$ a 01/06/00; Época $3=02 / 06 / 00$ a 12/08/00 e Época $4=18 / 09 / 00$ a 03/01/01.

Tabela 37. Quantidade de forragem perdida (PERHA) em função dos tratamentos e das épocas do ano ${ }^{1}$.

\begin{tabular}{|c|c|c|c|c|c|}
\hline \multirow[b]{2}{*}{ Época ${ }^{3}$} & \multicolumn{3}{|c|}{ Tratamento ${ }^{2}$} & \multirow{2}{*}{\multicolumn{2}{|c|}{ Média }} \\
\hline & 1 & 2 & 3 & & \\
\hline \multicolumn{6}{|c|}{ PERHA - (kg MS/ha/ciclo) } \\
\hline 1 & 677 & 1278 & 2137 & 1364 & $a$ \\
\hline 2 & 662 & 1401 & 2101 & 1388 & $\mathrm{a}$ \\
\hline 3 & 430 & 718 & 922 & 690 & b \\
\hline 4 & 726 & 1304 & 1719 & 1249 & a \\
\hline
\end{tabular}

$\begin{array}{lllllll}\text { Média } & 624 & \text { A } & 1175 & \text { B } & 1720 & \text { C }\end{array}$

1 - Médias seguidas da mesma letra (maiúsculas na linha e minúsculas na coluna) diferem pelo teste $t$ quando $\mathrm{p}<0.05$.

2 - 1500, 2500 e $4000 \mathrm{~kg} / \mathrm{ha}$ de matéria seca verde pós pastejo para T1, T2 e T3, respectivamente.

3 - Época 1 = 30/10/99 a 14/02/00; Época $2=15 / 02 / 00$ a 01/06/00; Época $3=02 / 06 / 00$ a $12 / 08 / 00$ e Época 4 = 18/09/00 a 03/01/01. 
Entretanto pela Tabela 38 observa-se que na época 2 a participação de material verde na forragem perdida é maior do que na época 4 indicando maiores perdas de material verde na época 2 do que na 4 . Desse modo, a lotação animal foi menor para atender os valores proposto para os tratamentos. Esse fato é confirmado quando observa-se na Tabela 39 que a quantidade de haste perdida na época 2 é maior do que na época 4 já que, a quantidade de folhas perdidas (Tabela 40), que é o outro componente da matéria seca verde, é igual entre as épocas 2 e 4.

Tabela 38. Participação de material morto na forragem perdida (MMPER\%) em função dos tratamentos e das épocas do ano ${ }^{1}$.

\begin{tabular}{|c|c|c|c|c|c|}
\hline \multirow[b]{2}{*}{ Época ${ }^{3}$} & \multicolumn{3}{|c|}{ Tratamento $^{2}$} & \multirow[b]{2}{*}{ Média } & \\
\hline & 1 & 2 & 3 & & \\
\hline \multicolumn{6}{|c|}{ MMPE\% } \\
\hline 1 & - & - & - & - & \\
\hline 2 & $50 \%$ & $39 \%$ & $32 \%$ & $40 \%$ & a \\
\hline 3 & $81 \%$ & $73 \%$ & $68 \%$ & $74 \%$ & b \\
\hline 4 & $66 \%$ & $49 \%$ & $50 \%$ & $55 \%$ & c \\
\hline
\end{tabular}

$\begin{array}{lllllll}\text { Média } & 66 \% & \mathrm{~A} & 54 \% & \mathrm{~B} & 50 \% & \mathrm{~B}\end{array}$

1 - Médias seguidas da mesma letra (maiúsculas na linha e minúsculas na coluna) diferem pelo teste $\mathrm{t}$ quando $\mathrm{p}<0.05$.

2 - 1500, 2500 e $4000 \mathrm{~kg} / \mathrm{ha}$ de matéria seca verde pós pastejo para T1, T2 e T3, respectivamente.

3 - Época 1 = 30/10/99 a 14/02/00; Época $2=15 / 02 / 00$ a 01/06/00; Época $3=02 / 06 / 00$ a 12/08/00 e Época $4=18 / 09 / 00$ a 03/01/01. 
Tabela 39. Quantidade de haste perdida por ha (HPEHA) em função dos tratamentos e das épocas do ano ${ }^{1}$.

\begin{tabular}{|c|c|c|c|c|c|c|c|c|}
\hline \multirow[b]{2}{*}{ Época ${ }^{3}$} & \multicolumn{6}{|c|}{ Tratamento $^{2}$} & \multirow[b]{2}{*}{ Média } & \\
\hline & 1 & & 2 & & 3 & & & \\
\hline \multicolumn{9}{|c|}{ HPEHA - (kg MS/ha/ciclo) } \\
\hline 1 & - & & - & & - & & - & \\
\hline 2 & 166 & & 532 & & 951 & & 550 & a \\
\hline 3 & 46 & & 143 & & 206 & & 132 & $b$ \\
\hline 4 & 151 & & 316 & & 407 & & 291 & C \\
\hline Média & 121 & $A$ & 330 & $\mathrm{~B}$ & 521 & $\mathrm{C}$ & & \\
\hline $\begin{array}{l}\text { - Médias } \\
\text { quando p< } \\
2-1500,25 \\
3 \text { - Época } \\
\text { Época } 4=\end{array}$ & $\begin{array}{l}\text { a mes } \\
\mathrm{kg} / \mathrm{ha} \mathrm{c} \\
9 \mathrm{a} \quad 1 \\
3 / 01 / \mathrm{C}\end{array}$ & a let & $\begin{array}{l}\text { sculas } \\
\text { verde } \\
2=1\end{array}$ & linha & $\begin{array}{l}\text { sculas } \\
\text { T1, T' } \\
\text { /00; Ép }\end{array}$ & colur & rem pe & $\begin{array}{l}\text { este } \\
\text { /00 }\end{array}$ \\
\hline
\end{tabular}

Tabela 40. Quantidade de folhas perdidas por ha (FPEHA) em função dos tratamentos e das épocas do ano ${ }^{1}$.

\begin{tabular}{|c|c|c|c|c|c|}
\hline \multirow[b]{2}{*}{ Época ${ }^{3}$} & \multicolumn{3}{|c|}{ Tratamento $^{2}$} & \multirow{2}{*}{\multicolumn{2}{|c|}{ Média }} \\
\hline & 1 & 2 & 3 & & \\
\hline \multicolumn{5}{|c|}{ FPEHA - (kg MS/ha/ciclo) } & \\
\hline 1 & - & - & - & - & \\
\hline 2 & 140 & 374 & 541 & 352 & a \\
\hline 3 & 53 & 86 & 117 & 85 & b \\
\hline 4 & 143 & 437 & 513 & 364 & $\mathrm{a}$ \\
\hline
\end{tabular}

$\begin{array}{lllllll}\text { Média } & 112 & \text { A } & 299 & \text { B } & 391 & \text { B }\end{array}$

1 - Médias seguidas da mesma letra (maiúsculas na linha e minúsculas na coluna) diferem pelo teste $t$ quando $\mathrm{p}<0.05$.

2 - 1500, 2500 e $4000 \mathrm{~kg} / \mathrm{ha}$ de matéria seca verde pós pastejo para T1, T2 e T3, respectivamente.

3 - Época $1=30 / 10 / 99$ a 14/02/00; Época $2=15 / 02 / 00$ a 01/06/00; Época $3=02 / 06 / 00$ a 12/08/00 e Época $4=18 / 09 / 00$ a 03/01/01. 
A analise em conjunto dos processos de perdas, disponibilidade de forragem e características morfológicas das plantas podem auxiliar na discussão dos resultados do ganho de peso vivo (GPV). Os resultados das Tabela 29 e 41 mostram que GPV nos T2 e T3 foram iguais entre si mas superiores ao T1.

Tabela 41. Média dos ganho de peso vivo (GPV) em função dos tratamentos e das épocas do ano ${ }^{1}$.

\begin{tabular}{|c|c|c|c|c|c|}
\hline \multirow[b]{2}{*}{ Época $^{3}$} & \multicolumn{3}{|c|}{ Tratamento $^{2}$} & \multirow{2}{*}{\multicolumn{2}{|c|}{ Média }} \\
\hline & 1 & 2 & 3 & & \\
\hline \multicolumn{6}{|c|}{ GPV - (g/cab/dia) } \\
\hline 1 & 299 & 528 & 551 & 459 & $\mathrm{a}$ \\
\hline 2 & 530 & 646 & 572 & 583 & $b$ \\
\hline 3 & 271 & 417 & 458 & 382 & c \\
\hline 4 & 493 & 574 & 674 & 580 & $b$ \\
\hline
\end{tabular}

$\begin{array}{lllllll}\text { Média } & 398 & \mathrm{~A} & 541 & \mathrm{~B} & 564 & \mathrm{~B}\end{array}$

1 - Médias seguidas da mesma letra (maiúsculas na linha e minúsculas na coluna) diferem pelo teste $t$ quando $\mathrm{p}<0.05$.

2 - 1500, 2500 e $4000 \mathrm{~kg} / \mathrm{ha}$ de matéria seca verde pós pastejo para T1, T2 e T3, respectivamente.

3 - Época 1 = 30/10/99 a 14/02/00; Época $2=15 / 02 / 00$ a 01/06/00; Época $3=02 / 06 / 00$ a 12/08/00 e Época $4=18 / 09 / 00$ a 03/01/01.

A densidade de forragem nas pastagens (DP) e a relação folha/haste (FHP) são características que tem influência sobre o consumo e consequentemente sobre o desempenho animal (Stobbs, 1973; Stobbs, 1975 e Carvalho et al., 2001a). Como discutido no item 4.3. a DP não foi alterada pelos tratamentos, assim como o formato da planta. Portanto a densidade pouco contribuirá para explicar o comportamento da variável GPV assim como o formato da planta e sua disposição no dossel da pastagem.

Segundo Stobbs, (1973) e Gomide et al. (2001) o desempenho animal é favorecido com o aumento da relação folha/haste. Entretanto os resultados obtidos neste trabalho indicam o contrário ou seja, a relação folha/haste foi 
superior no tratamento de menor GPV (T1) (Tabela 41). Os trabalhos de Bortolo et al. 2001a e Bortolo et al. 2001b que foram conduzidos em lotação continua com carga variável apresentaram resultado semelhantes.

Como podemos observar a relação folha/haste no resíduo (FHR) (Tabela 42) é bem menor do que a FHP. Dessa forma parece ser mais razoável analisar o GPV em relação aos valores médios das relações folha/haste das pastagens antes e após o pastejo (FHM) (Tabela 43).

Pelos resultados expostos na Tabela 43 concluímos que a FHM também foi menor nos tratamentos (T2 e T3) onde foram registrados os melhores GPV. Desse modo a relação folha/haste assim como a densidade de forragem são parâmetros que contribuíram pouco para justificar o desempenho dos animais. Portanto, resta para o momento avaliar o desempenho animal em função da disponibilidade de forragem uma vez que, segundo Gomide, (1993) e Hodgson (1990), a disponibilidade de forragem e o consumo estão relacionadas com o desempenho animal.

A forragem ofertada (OFEPP) no início do pastejo é maior para a época 2 e semelhante para as épocas 1, 3 e 4 (Tabela 44). No final do pastejo a oferta de forragem (Tabela 45) (OFER) é menor do que a OFEPP, assim do mesmo modo que se calculou a relação média de folhas/haste procurou-se determinar as ofertas médias de matéria seca verde total (OFEPM), folhas (OFEFM) e haste (OFEHM) (Tabelas 46, 47 e 48, respectivamente).

Como determinaram Bortolo et al. (2001b) e Almeida et al. (2000b) os resultados das Tabelas 41 e 46, se comparados, permite inferir que existe uma relação assintótica entre o GPV e a OFEPM uma vez que o GPV aumentou até o T2 mantendo-se semelhante ao T3 embora os valores da OFEPM tenham aumentado do T1 até o T3. 
Tabela 42. Relação folha/haste média nas pastagens após os pastejos (FHR) em função dos tratamentos e das épocas do ano ${ }^{1}$.

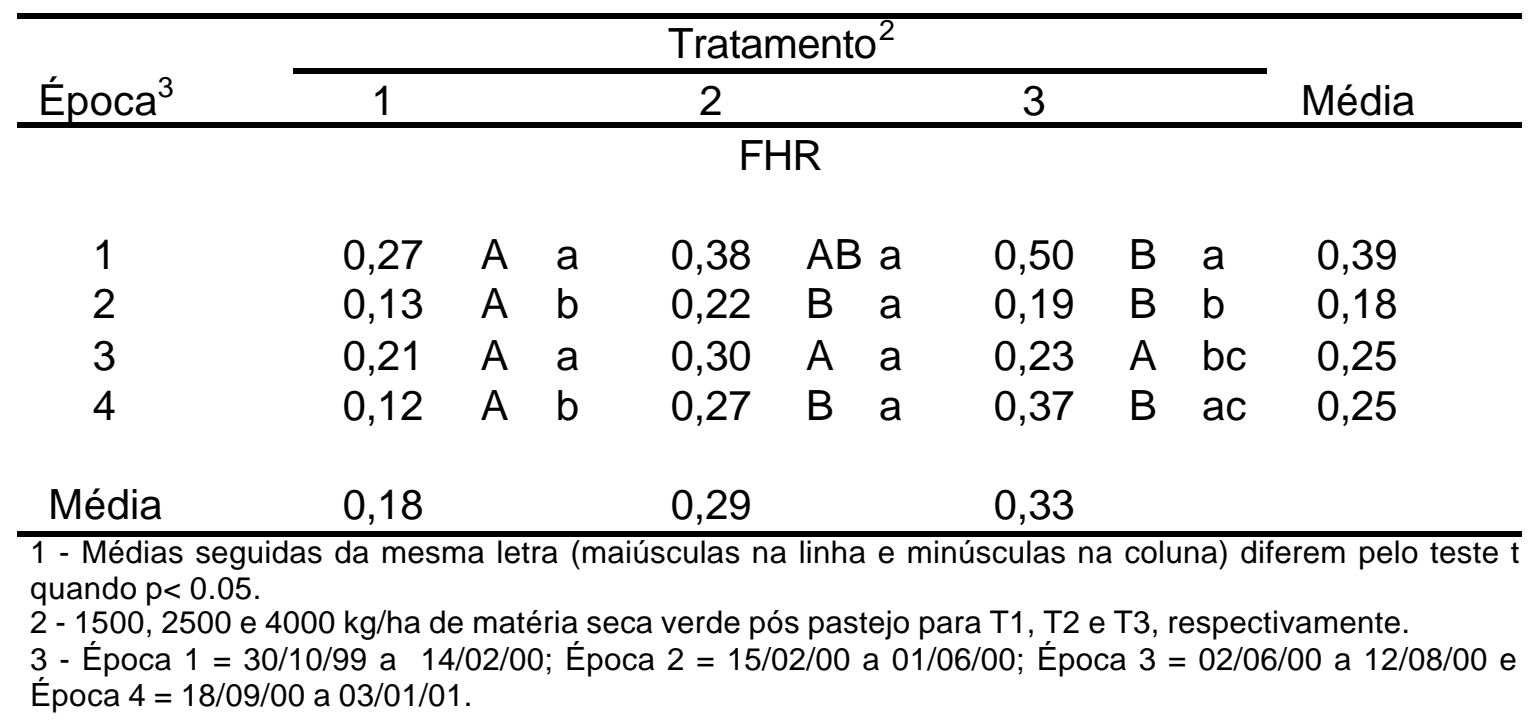

Tabela 43. Média das relações folha/haste média nas pastagens antes e após os pastejos (FHM) em função dos tratamentos e das épocas do ano ${ }^{1}$.

\begin{tabular}{|c|c|c|c|c|c|}
\hline \multirow[b]{2}{*}{ Época ${ }^{3}$} & \multicolumn{3}{|c|}{ Tratamento $^{2}$} & \multirow{2}{*}{\multicolumn{2}{|c|}{ Média }} \\
\hline & 1 & 2 & 3 & & \\
\hline \multicolumn{6}{|c|}{ FHM } \\
\hline 1 & 1,15 & 1,03 & 0,96 & 1,05 & a \\
\hline 2 & 0,67 & 0,57 & 0,48 & 0,57 & $b$ \\
\hline 3 & 1,09 & 0,64 & 0,55 & 0,76 & c \\
\hline 4 & 0,76 & 0,68 & 0,73 & 0,72 & c \\
\hline
\end{tabular}

$\begin{array}{lllllll}\text { Média } & 0,92 & \mathrm{~A} & 0,73 & \mathrm{~B} & 0,68 & \mathrm{~B}\end{array}$

1 - Médias seguidas da mesma letra (maiúsculas na linha e minúsculas na coluna) diferem pelo teste $t$ quando $\mathrm{p}<0.05$.

2 - 1500, 2500 e $4000 \mathrm{~kg} / \mathrm{ha}$ de matéria seca verde pós pastejo para T1, T2 e T3, respectivamente.

3 - Época $1=30 / 10 / 99$ a 14/02/00; Época 2 = 15/02/00 a 01/06/00; Época $3=02 / 06 / 00$ a 12/08/00 e Época $4=18 / 09 / 00$ a 03/01/01. 
Tabela 44. Oferta de matéria seca verde antes dos pastejos (OFEPP) em função dos tratamentos e das épocas do ano ${ }^{1}$.

\begin{tabular}{|c|c|c|c|c|c|}
\hline \multirow[b]{2}{*}{ Época $^{3}$} & \multicolumn{3}{|c|}{ Tratamento $^{2}$} & \multirow{2}{*}{\multicolumn{2}{|c|}{ Média }} \\
\hline & 1 & 2 & 3 & & \\
\hline \multicolumn{6}{|c|}{ OFEPP - (kg MSV/100 kg PV) } \\
\hline 1 & 9,9 & 18,3 & 28,3 & 18,8 & a \\
\hline 2 & 13,6 & 25,4 & 36,9 & 25,3 & b \\
\hline 3 & 5,1 & 11,6 & 20,7 & 12,5 & $\mathrm{a}$ \\
\hline 4 & 9,2 & 18,4 & 24,6 & 17,4 & a \\
\hline
\end{tabular}

$\begin{array}{lllllll}\text { Média } & 9,4 & \mathrm{~A} & 18,4 & \mathrm{~B} & 27,6 & \mathrm{C}\end{array}$

1 - Médias seguidas da mesma letra (maiúsculas na linha e minúsculas na coluna) diferem pelo teste $t$ quando $\mathrm{p}<0.05$.

2 - 1500, 2500 e $4000 \mathrm{~kg} / \mathrm{ha}$ de matéria seca verde pós pastejo para T1, T2 e T3, respectivamente.

3 - Época 1 = 30/10/99 a 14/02/00; Época $2=15 / 02 / 00$ a 01/06/00; Época $3=02 / 06 / 00$ a 12/08/00 e Época $4=18 / 09 / 00$ a 03/01/01.

Tabela 45. Oferta de matéria seca verde após os pastejos (OFEPR) em função dos tratamentos e das épocas do ano ${ }^{1}$.

\begin{tabular}{cccccc}
\hline & \multicolumn{4}{c}{ Tratamento $^{2}$} & \multirow{2}{*}{ Média } \\
\cline { 2 - 4 } Época $^{3}$ & 1 & 2 & 3 & & \\
& \multicolumn{5}{c}{ OFEPR - $(\mathrm{kg} \mathrm{MSV} / 100 \mathrm{~kg} \mathrm{PV})$} \\
1 & 4,2 & 9,3 & 16,3 & 9,9 & $\mathrm{a}$ \\
2 & 6,1 & 12,9 & 22,7 & 13,9 & $\mathrm{~b}$ \\
3 & 3,7 & 13,3 & 20,5 & 12,5 & $\mathrm{ab}$ \\
4 & 2,6 & 9,9 & 20,6 & 11,0 & $\mathrm{a}$
\end{tabular}

$\begin{array}{lllllll}\text { Média } & 4,1 & \mathrm{~A} & 11,3 & \mathrm{~B} & 20,0 & \mathrm{C}\end{array}$

1 - Médias seguidas da mesma letra (maiúsculas na linha e minúsculas na coluna) diferem pelo teste $t$ quando $\mathrm{p}<0.05$.

2 - 1500, 2500 e $4000 \mathrm{~kg} / \mathrm{ha}$ de matéria seca verde pós pastejo para T1, T2 e T3, respectivamente.

3 - Época $1=30 / 10 / 99$ a 14/02/00; Época $2=15 / 02 / 00$ a 01/06/00; Época $3=02 / 06 / 00$ a 12/08/00 e Época $4=18 / 09 / 00$ a 03/01/01. 
Tabela 46. Ofertas médias entre as ofertas de matéria seca verde antes e após os pastejos (OFEPM) em função dos tratamentos e das épocas do ano ${ }^{1}$.

\begin{tabular}{|c|c|c|c|c|c|}
\hline \multirow[b]{2}{*}{ Época ${ }^{3}$} & \multicolumn{3}{|c|}{ Tratamento $^{2}$} & \multirow[b]{2}{*}{ Média } & \\
\hline & 1 & 2 & 3 & & \\
\hline \multicolumn{5}{|c|}{ OFEPM - (kg MSV/100 kg PV) } & \\
\hline 1 & 7,0 & 13,8 & 22,3 & 14,4 & \\
\hline 2 & 9,8 & 19,2 & 29,8 & 19,6 & \\
\hline 3 & 4,4 & 12,4 & 20,6 & 12,5 & a \\
\hline 4 & 5,9 & 14,2 & 22,6 & 14,2 & a \\
\hline
\end{tabular}

$\begin{array}{lllllll}\text { Média } & 6,8 & \mathrm{~A} & 14,9 & \mathrm{~B} & 23,8 & \mathrm{C}\end{array}$

1 - Médias seguidas da mesma letra (maiúsculas na linha e minúsculas na coluna) diferem pelo teste $t$ quando $\mathrm{p}<0.05$.

2 - 1500, 2500 e $4000 \mathrm{~kg} / \mathrm{ha}$ de matéria seca verde pós pastejo para T1, T2 e T3, respectivamente.

3 - Época 1 = 30/10/99 a 14/02/00; Época 2 = 15/02/00 a 01/06/00; Época $3=02 / 06 / 00$ a 12/08/00 e Época $4=18 / 09 / 00$ a 03/01/01.

Tabela 47. Ofertas médias entre as ofertas de folhas antes e após os pastejos (OFEFM) em função dos tratamentos e das épocas do ano ${ }^{1}$.

\begin{tabular}{cccccc}
\hline & \multicolumn{4}{c}{ Tratamento } & \multirow{2}{*}{ Média } \\
\cline { 2 - 4 } Época & 1 & 2 & 3 & & \\
& \multicolumn{5}{c}{ OFEFM - $(\mathrm{kg} \mathrm{MS} / 100 \mathrm{~kg} \mathrm{PV})$} \\
1 & 3,9 & 7,2 & 11,2 & 7,4 & $\mathrm{a}$ \\
2 & 4,0 & 7,0 & 9,6 & 6,9 & $\mathrm{a}$ \\
3 & 1,9 & 4,2 & 6,0 & 4,0 & $\mathrm{~b}$ \\
4 & 2,8 & 5,9 & 9,1 & 5,9 & $\mathrm{c}$
\end{tabular}

$\begin{array}{lllllll}\text { Média } & 3,2 & \mathrm{~A} & 6,1 & \mathrm{~B} & 9,0 & \mathrm{C}\end{array}$

1 - Médias seguidas da mesma letra (maiúsculas na linha e minúsculas na coluna) diferem pelo teste $\mathrm{t}$ quando $\mathrm{p}<0.05$.

2 - 1500, 2500 e $4000 \mathrm{~kg} / \mathrm{ha}$ de matéria seca verde pós pastejo para T1, T2 e T3, respectivamente.

3 - Época $1=30 / 10 / 99$ a 14/02/00; Época $2=15 / 02 / 00$ a 01/06/00; Época $3=02 / 06 / 00$ a 12/08/00 e Época $4=18 / 09 / 00$ a 03/01/01. 
Tabela 48. Ofertas médias entre as ofertas de haste antes e após os pastejos (OFEHM) em função dos tratamentos e das épocas do ano ${ }^{1}$.

\begin{tabular}{|c|c|c|c|c|c|c|c|c|}
\hline \multirow[b]{2}{*}{ Época ${ }^{3}$} & \multicolumn{6}{|c|}{ Tratamento $^{2}$} & \multirow{2}{*}{\multicolumn{2}{|c|}{ Média }} \\
\hline & 1 & & 2 & & 3 & & & \\
\hline \multicolumn{9}{|c|}{ OFEHM - (kg MS/100 kg PV) } \\
\hline 1 & 3,2 & & 6,7 & & 11,1 & & 7,0 & a \\
\hline 2 & 5,8 & & 12,2 & & 20,2 & & 12,7 & $b$ \\
\hline 3 & 2,4 & & 8,2 & & 14,6 & & 8,4 & a \\
\hline 4 & 3,1 & & 8,3 & & 13,5 & & 8,3 & a \\
\hline Média & 3,6 & A & 8,9 & B & 14,9 & C & & \\
\hline $\begin{array}{l}1-\text { Médias } \\
\text { quando p<C } \\
2-1500,25 \\
3-\text { Época } 1 \\
\text { Época } 4=1\end{array}$ & $\mathrm{a}$ & & & & culas & & & este $\mathrm{t}$ \\
\hline
\end{tabular}

Esses resultados estão de acordo com os trabalhos de Hodgson (1990), Ribeiro et al. (1997), Almeida et al. (2000b), Bortolo et al. (2001b) e Barbosa et al. (2001b) que mostraram a relação assintótica ou quadrática da oferta de forragem com o consumo e/ou desempenho animal. Portanto, quando os resultados apresentados nas Tabelas 41 (GPV) e 46 são analisados pode-se inferir que a partir de $14,9 \mathrm{~kg}$ MSV/100 kg PV não há incremento significativos no GPV. Esse resultado esta coerente com os trabalhos de Hodgson (1990) e de Ribeiro et al. (1997) onde o consumo de forragem cresceu linearmente até a oiferta de $12 \mathrm{~kg} \mathrm{MS} / 100 \mathrm{~kg}$ PV e acima desse valor os incrementos de consumo foram reduzidos.

Desse mesmo modo é possível justificar o fato do GPV nas épocas 2 e 4 serem iguais apesar das ofertas médias de forragem serem diferentes (Tabela 46). Além disso a oferta de folhas são iguais entre essas épocas e segundo Bortolo et al. (2001b) expressar a oferta de forragem através da oferta de folhas é mais indicado quando se avalia o desempenho animal. Os resultados da Tabela 47 parece indicar que a ofertas de folhas ao redor de 6,1 $\mathrm{kg}$ MS de 
folhas/100 kg PV permite os melhores GPV. Almeida e al. (2000b) e Barbosa et al. (2001b) apresentaram valores de 7,5 e de 8 a $11 \mathrm{~kg}$ de folhas/100 kg PV, para capim Elefante anão e capim Tanzânia, respectivamente.

O comportamento assintótico entre a OFEPM e o GPV não justifica a diferença entre os desempenhos dos animais nas épocas 1 e 4 já que as ofertas de forragem foram igual nessas duas épocas. Entretanto as perdas de forragem por UA (PERUA) foram maiores na época 1 do que na época 4 (Tabela 49) e assim a oferta de forragem na época 1 deve ter sido menor do que $14,4 \mathrm{~kg} \mathrm{MSV} / 100 \mathrm{~kg}$ PV (Tabela 49).

Tabela 49. Perdas de matéria seca por unidade animal (PERUA) em função dos tratamentos e das épocas do ano ${ }^{1}$.

\begin{tabular}{|c|c|c|c|c|c|}
\hline \multirow[b]{2}{*}{ Época $^{3}$} & \multicolumn{3}{|c|}{ Tratamento $^{2}$} & \multirow[b]{2}{*}{ Média } & \\
\hline & 1 & 2 & 3 & & \\
\hline \multicolumn{5}{|c|}{ PERUA (kg MS/100 kg de PV) } & \\
\hline 1 & 2,2 & 4,5 & 8,4 & 5,0 & \\
\hline 2 & 2,3 & 5,2 & 8,6 & 5,4 & $\mathrm{a}$ \\
\hline 3 & 1,8 & 3,9 & 6,0 & 3,9 & b \\
\hline 4 & 1,5 & 4,0 & 6,4 & 4,0 & b \\
\hline
\end{tabular}

$\begin{array}{lllllll}\text { Média } & 1,9 & \text { A } & 4,4 & \text { B } & 7,4 & \text { C }\end{array}$

1 - Médias seguidas da mesma letra (maiúsculas na linha e minúsculas na coluna) diferem pelo teste $\mathrm{t}$ quando $\mathrm{p}<0.05$.

2 - 1500, 2500 e $4000 \mathrm{~kg} / \mathrm{ha}$ de matéria seca verde pós pastejo para T1, T2 e T3, respectivamente.

3 - Época 1 = 30/10/99 a 14/02/00; Época 2 = 15/02/00 a 01/06/00; Época $3=02 / 06 / 00$ a 12/08/00 e Época 4 = 18/09/00 a 03/01/01.

Desse modo, conclui-se que a oferta média de forragem durante 0 período de ocupação de $14,9 \mathrm{~kg}$ MSV/100 kg PV ou de $6,1 \mathrm{~kg}$ de folhas $/ 100 \mathrm{~kg}$ PV permite melhores GPV dos animais. 


\subsection{Produtividade animal}

A produção animal por área é reflexo do desempenho e da lotação animal. Como em outras culturas o aumento na produtividade é a principal ferramenta utilizada por técnicos e produtores para reduzir o custo da produção. Existem momentos onde o desempenho animal tem prioridade à lotação e consequentemente à produtividade, como por exemplo, quando é necessário acelerar a engorda dos animais para comercializa-los quando o preço da arroba esta alto. Para tanto torna-se necessário aumentar a oferta de forragem e desse modo poderá ocorrer sobra de forragem no pasto. Também surgirão situações onde o desempenho animal será prejudicado em detrimento da necessidade de realizar um pastejo severo para reduzir a forragem acumulada no pasto.

Como ocorreu nos trabalhos Bortolo et al. (2001b); Barbosa et al. (2001b); Almeida et al. (2000b) a expectativa era de que a produtividade animal (PRODU) diminuísse com o aumento na oferta de forragem. No entanto, a produção animal acumulada no final do experimento não foi alterada pela MFVR $(1518,1419$ e $1287 \mathrm{~kg}$ de PV/ha para os T1, T2, e T3, respectivamente Tabela 29) ou mesmo pela oferta de forragem. Esse resultado é explicado pelo balanço entre o GPV e LA, ou seja, no T1 o baixo ganho de peso foi compensado pela maior lotação e nos T2 e T3 as menores lotações foram compensados pelos GPV maiores.

Entretanto quando se compara o efeito dos tratamentos sobre a produtividade dentro de cada época, constata-se respostas diferentes como aconteceu nas épocas 2 e 4 onde foram detectados efeito dos tratamentos (Tabela 50). Esse fato deve merecer atenção quando se analisa trabalhos para avaliar a produtividade animal uma vez que observações realizadas por curto período de tempo podem distorcer resultados.

As menores produtividades obtidas na época 3 ocorreu porque nessa época foram registrados as menores lotações e os piores GPV. 
Tabela 50. Produtividade animal por ha (PRODU) em função dos tratamentos e das épocas do ano ${ }^{1}$.

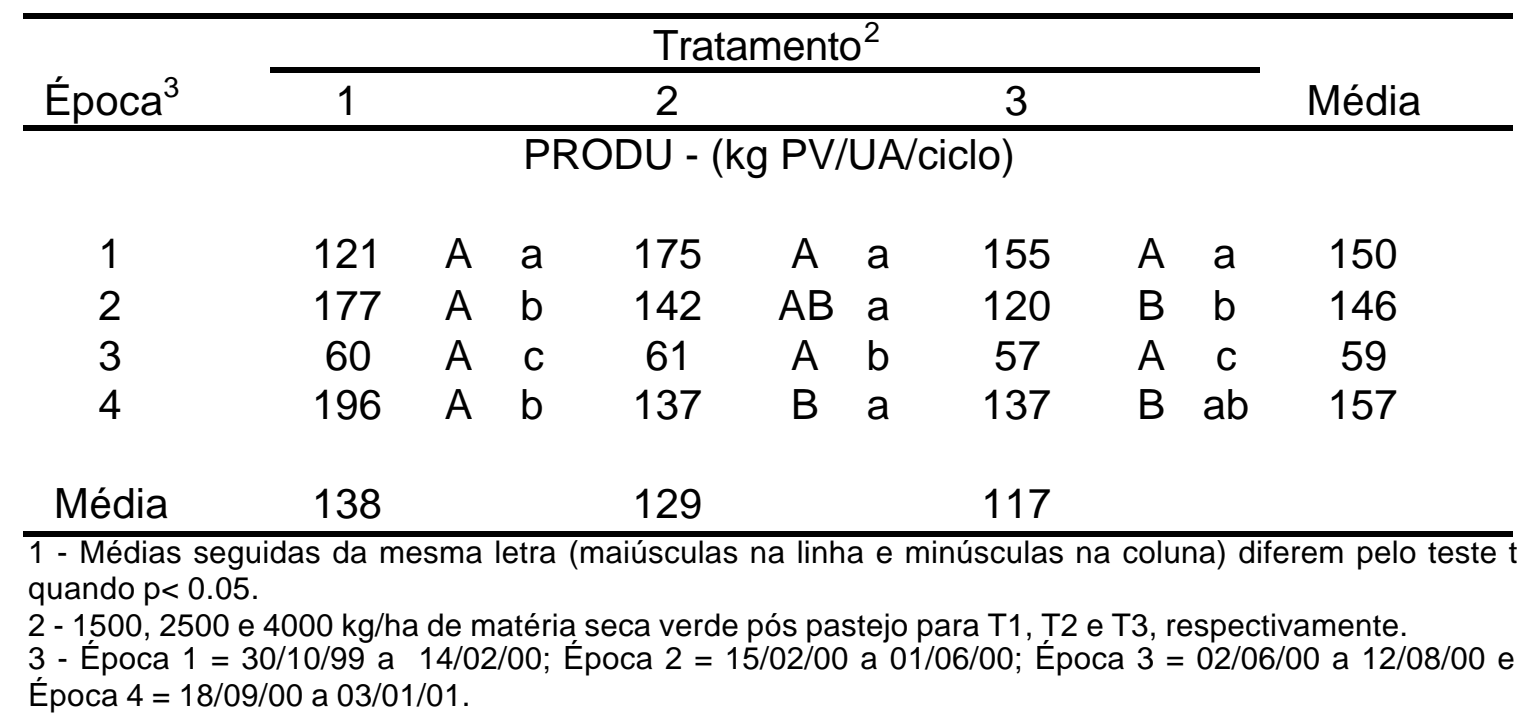

Apesar das PRODU no final do experimento serem iguais os animais do T1 teriam que ficar em pastejo por mais 154 dias [(445 $\mathrm{kg}-384 \mathrm{~kg}) / 0,397$ $\mathrm{kg} / \mathrm{dia}$ )] (Tabela 28) para alcançarem o mesmo peso vivo dos animais que estavam nos T2 e T3. Desse modo o manejo mais adequado seria o de manter a MFVR superior a $2915 \mathrm{~kg} \mathrm{MSV/ha} \mathrm{e} \mathrm{a} \mathrm{oferta} \mathrm{de} 14,9 \mathrm{~kg} \mathrm{MSV} / 100 \mathrm{~kg} P V$ ou de $6,1 \mathrm{~kg}$ de folhas $/ 100 \mathrm{~kg} \mathrm{PV}$. 


\section{CONCLUSÕES}

A avaliação da massa de forragem em pastagens estabelecidas com

plantas forrageiras de hábito de crescimento cespitoso deve ser realizada através do uso de quatro amostras de $1 \mathrm{~m}^{2}(1 \mathrm{~m} \times 1 \mathrm{~m})$ para estimar a produção em área de 1333 a $2000 \mathrm{~m}^{2}$.

A profundidade de pastejo esta relacionada linearmente com a altura da planta independentemente da disponibilidade de forragem e do dia de ocupação do pasto para a altura da planta variando de 8 a $150 \mathrm{~cm}$ quando da entrada dos animais no piquete.

A avaliação dos estratos inferiores do perfil do dossel das pastagens devem merecer mais atenção do que os estratos superiores nos estudos envolvendo comportamento e desempenho animal. Nos estratos inferiores a densidade de forragem atingiu valores superiores (91 a $121 \mathrm{~kg} \mathrm{MSV} / \mathrm{cm} / \mathrm{ha}$ ) do que nos estratos inferiores (7 a $19 \mathrm{~kg} \mathrm{MSV} / \mathrm{cm} / \mathrm{ha}$ ).

A intensidade de pastejo não teve efeito sobre o angulo (em relação ao solo) de inclinação dos perfilhos mais externos da touceira, sobre o formato das touceiras e sobre a distribuição da densidade de forragem no perfil da pastagem indicando que o capim Tanzânia tem pouca plasticidade em relação a essas características. Entretanto, a proporção de haste, de folhas, de material morto, da altura, da relação folha/haste foram características morfológicas afetadas pelos tratamentos e épocas do ano. 
A taxa de cobertura do solo diminuiu durante o período experimental e estabilizou em $24 \%$ independentemente do tratamento. O mesmo não ocorreu com o tamanho as touceiras que foram alteradas pelo manejo. $O$ tamanho das touceiras parece estar associada a mecanismos rápidos de adaptação da planta a mudanças no meio ambiente causadas pelas diferentes intensidades de pastejo.

Através do angulo de inclinação (a) dos perfilhos mais externos da touceira e da distância entre as touceiras (D) foi possível simular o ritmo de crescimento $(R C)$ da planta (e/ou touceira) através do modelo $R C=\{\operatorname{tg}$ a $(D / 2)$ $+(s(D) / 100)]\} / n$. Calculou-se o RC necessário para se obter $10 \%$ de sobreposição de folhas entre plantas vizinhas (s) em 20 dias (n) após o pastejo. Esse simulação permitiria monitorar a velocidade de rebrota e indicar a necessidade de realizar alterações no manejo.

A densidade de forragem e relação folha/haste pouco contribuíram para justificar as diferenças no desempenho dos animais que esteve relacionado com a oferta e disponibilidade de forragem no resíduo. As ofertas médias de forragem durante o período de ocupação dos piquetes ao nível de $14,9 \mathrm{~kg} \mathrm{MSV} / 100 \mathrm{~kg}$ PV ou de $6,1 \mathrm{~kg}$ de folhas $/ 100 \mathrm{~kg}$ PV e a disponibilidade de forragem no resíduo de $2915 \mathrm{~kg} \mathrm{MSV/ha} \mathrm{permitiram} \mathrm{os} \mathrm{melhores} \mathrm{desempenhos}$ dos animais que foi de $541 \mathrm{~g} / \mathrm{cab} /$ dia durante o período de 14 meses.

Os aumentos de produção acumulada de massa de forragem com a redução na intensidade de pastejo não foi traduzida em incrementos na produtividade animal em decorrência da menor eficiência de pastejo nos tratamento de baixa intensidade (47\%) em relação ao sistema de pastejo mais severo $(75 \%)$.

Apesar da produtividade animal não ser alterada pelos tratamentos, o manejo mais adequado seria o de manter massa de forragem no resíduo (MFVR) superior a $2915 \mathrm{~kg} \mathrm{MSV/ha} \mathrm{porque} \mathrm{a} \mathrm{idade} \mathrm{dos} \mathrm{animais} \mathrm{para} \mathrm{abate}$ (445 kg de PV) seria reduzido em 150 dias quando comparado ao tratamento de $1266 \mathrm{~kg} \mathrm{MSV/ha} \mathrm{de} \mathrm{MFVR.}$ 


\section{REFERÊNCIAS BIBLIOGRÁFICAS}

AGUIAR, S.V.H.; BALSALOBRE, M.A.A.; LABONIA, V.D.S. et al. Proporção de partes morfológicas do capim Tanzânia (Panicum maximum Jacq.) em três intensidades de pastejo ao longo do ano. In: REUNIÃO ANUAL DA SOCIEDADE BRASILEIRA DE ZOOTECNIA, 38., Piracicaba, 2001. Anais. Piracicaba: SBZ, 2001. p.342-343.

ALMEIDA, E.X.; MARASCHIN, G.E.; HARTHMANN, O.E.L. et al. Oferta de forragen de Capim-Elefante Anão "Mott" e a dinâmica da pastagem. Revista da Sociedade Brasileira de Zootecnia, v.29, n.5, p.1281-1287, 2000a.

ALMEIDA, E.X.; MARASCHIN, G.E.; HARTHMANN, O.E.L. et al. Oferta de forragen de Capim-Elefante Anão "Mott" e o rendimento animal, Revista da Sociedade Brasileira de Zootecnia, v.29, n.5, p.1288-1295, 2000b.

ARRUDA, Z.J. A pecuária bovina de corte no Brasil e resultados econômicos de sistemas alternativos de produção. In: SIMPÓSIO SOBRE PECUÁRIA DE CORTE, 4., Piracicaba, 1977. Anais. Piracicaba: FEALQ, 1997. p. 259-273. 
BALSALOBRE, M.A.A. Desempenho de vacas em lactação sob pastejo rotacionado de capim Elefante (Pennisetum purpureum Schum.). Piracicaba, 1996. 139p. Dissertação (Mestrado) - Escola Superior de Agricultura "Luiz de Queiroz", Universidade de São Paulo.

BARBOSA, R.A.; EUCLIDES, V.P.B.; NASCIMENTO JÚNIOR, D. et al. Morfogênese do capim Tanzânia em duas intensidades de pastejo. In: REUNIÃO ANUAL DA SOCIEDADE BRASILEIRA DE ZOOTECNIA, 38., Piracicaba, 2001. Anais. Piracicaba: SBZ, 2001a. p.95-96.

BARBOSA, M.A.A.F.; NASCIMENTO JÚNIOR, D.; CECATO, U. et al. Desempenho de novilhos em capim Tanzânia com diferentes ofertas de forragem. In: REUNIÃO ANUAL DA SOCIEDADE BRASILEIRA DE ZOOTECNIA, 38., Piracicaba, 2001. Anais. Piracicaba: SBZ, 2001b. p.287-288.

BORTOLO, M.; CECATO, U.; MARTINS, E.N. et al. Avaliação de uma pastagem de Coastcross - 1 (Cynodon dactylon (L.) Pers) sob diferentes níveis de matéria seca residual. Revista da Sociedade Brasileira de Zootecnia, v.30, n.3, p.627-635, 2001a.

BORTOLO, M.; CECATO, U.; MACEDO, F.A.F. et al. Desempenho de ovelhas, composição química e digestibilidade in vitro em uma pastagem de Coastcross - 1 (Cynodon dactylon (L.) Pers) sob diferentes níveis de matéria seca residual. Revista da Sociedade Brasileira de Zootecnia, v.30, n.3, p.636-643, 2001b. 
BRÂNCIO, P.A.; NASCIMENTO JUNIOR, D.; EUCLIDES, V.P.B. et al. Avaliação de três cultivares de Panicum maximum Jacq. sob pastejo 1 - Disponibilidade de forragem, altura e profundidade de pastejo (compact disc). In: REUNIÃO ANUAL DA SOCIDEDADE BRASILEIRA DE ZOOTECNIA, 37., Viçosa, 2000. Anais. Viçosa: SBZ, 2000.

BURNS, J.C.; POND, K.R.; FISHER, D.S. Effects of grass species on grazing steers: II. Dry matter intake and digest kinetics. Journal Animal Science, v.69, n.3, p.1199-1204, 1991.

CANO, C.C.P.; CECATO, U.; CANTO, M.W. et al. Avaliação de características morfogênicas do Capim Tanzânia (Panicum maximum Jacq. cv. Tanzânia1) em diferentes alturas da pastagem sob pastejo. In: REUNIÃO ANUAL DA SOCIEDADE BRASILEIRA DE ZOOTECNIA, 38., Piracicaba, 2001. Anais. Piracicaba: SBZ, 2001a. p.332-334.

CANO, C.C.P.; CECATO, U.; CANTO, M.W. et al. Densidade populacional de perfilhos e altura do meristema apical do Capim Tanzânia (Panicum maximum Jacq. cv. Tanzânia-1) em diferentes alturas da pastagem sob pastejo. In: REUNIÃO ANUAL DA SOCIEDADE BRASILEIRA DE ZOOTECNIA, 38., Piracicaba, 2001. Anais. Piracicaba: SBZ, 2001b. p.334-335.

CANTO, M.W.; CECATO, U.; PETERNELLI, M. et al. Efeito da altura do capim Tanzânia diferido nas características da pastagem no período do inverno. Revista da Sociedade Brasileira de Zootecnia, v.30, n.4, p.1186-1193, 2001. 
CARNEVALLI, R.A.; DA SILVA, S.C.; UEBELE, M.C. et al. Desempenho de ovinos e respostas de pastagens de Cynodon sp p. submetidos a regimes de desfolha sob lotação contínua (compact disc). In: REUNIÃO ANUAL DA SOCIDEDADE BRASILEIRA DE ZOOTECNIA, 37., Viçosa, 2000. Anais. Viçosa: SBZ, 2000.

CARVALHO, P.C.F.; RIBEIRO FILHO, H.M.N.; POLI, C.H.E. et al. Importância da estrutura da pastagem na ingestão e seleção de dietas pelo animal em pastejo. In: MATTOS W.R.S. (Ed.) A produção animal na visão dos brasileiros. Piracicaba: FEALQ; SBZ, 2001a. p.853-871.

CARVALHO, P.C.F.; MARÇAL, G.K.; RIBEIRO FILHO, H.M.N. et al. Pastagens altas podem limitar o consumo dos animais. In: REUNIÃO ANUAL DA SOCIEDADE BRASILEIRA DE ZOOTECNIA, 38., Piracicaba, 2001. Anais. Piracicaba: SBZ, 2001b. p.265-266.

CECATO, U.; CASTRO, C.R.C.; CANTO; M.W. et al. Perdas de forragem em capim Tanzânia (Panicum maximum Jacq cv. Tanzânia-1) manejado sob diferentes alturas de pastejo. Revista da Sociedade Brasileira de Zootecnia, v.30, n.2, p.295-301, 2001.

CORSI, M.; NUSSIO L.G. Manejo do capim elefante: correção e adubação do solo. In: SIMPÓSIO SOBRE MANEJO DA PASTAGEM, 10., Piracicaba, 1993. Anais. Piracicaba: FEALQ, 1993. p. 87-116.

COSTA, N.L.; TOWNSEND, C.R.; MAGALHÃES, J.A. et al. Avaliação agronômica sob pastejo de Panicum maximum cv. Tanzânia (compact disc). In: REUNIÃO ANUAL DA SOCIDEDADE BRASILEIRA DE ZOOTECNIA, 37., Viçosa, 2000. Anais. Viçosa: SBZ, 2000. 
COWAN, R.T.; LOWE, K.F. Tropical and subtropical grass management and quality. In: CHERNEY, J.H.; CHERNEY, D.J.R. Grass for dairy cattle.. Wallingford: CAB International, 1988. p.101-135.

DA SILVA, S.C.; FARIA, V.P.; CORSI, M. Sistema intensivo de produção de leite em pastagens de capim elefante do Departamento de Zootecnia da ESALQ. In: CONGRESSO BRASILEIRO DE GADO LEITEIRO, 2., Piracicaba, 1995. Anais. Piracicaba: FEALQ, 1996. p.97-122.

DAVIES, A. The regrowth of grass swards. In: JONES, M. B.; LAZENBY, A. (Ed.) The grass crop: the physiological basis of production. New York: Chapman and Hall, 1988. p. 85-127.

DAVIES, A.; EVANS. M.E.; EXLEY, J. K. Regrowth of perennial ryegrass as affected by simulated leaf sheaths. Journal of Agricultural Science, v. 101, p. 131-137, 1983.

FAGUNDES, J.L. Efeito de intensidades de pastejo sobre o índice de área foliar, interceptação luminosa e acúmulo de forragem em pastagens de Cynodon spp. Piracicaba, 1999, 69p. Dissertação (Mestrado) - Escola Superior de Agricultura "Luiz de Queiroz", Universidade de São Paulo.

FAHEY Jr., G. C.; HUSSEIN, H. S. Forty years of forage quality research: accomplishments and impact from an animal nutrition perspective. Crop Science, v. 39, p. 4-12, 1999.

FARIA, V. P. Evolução no uso de capim elefante: uma visão histórica. In: SIMPÓSIO SOBRE MANEJO DA PASTAGEM, 10., Piracicaba, 1994. Anais. Piracicaba: FEALQ, 1994. p.19-46. 
FARIA, V.P.; PEDREIRA, C.G.S.; SANTOS, F.A.P. Evolução do uso de pastagens para bovinos. In: SIMPÓSIO SOBRE MANEJO DA PASTAGEM, 13., Piracicaba, 1996. Anais. Piracicaba: FEALQ, 1996. p.1-14.

FRAME, J. Herbage mass. In: HODGSON, J.; BAKER, R.D.; DAVIES, A.; LAIDLAW, A.S.; LEAVER, J.D. (Ed.) Sward measurement handbook, Berkshire: British Grassland Society, Grassland Research Institute: Hurley, 1981. p.39-70.

GOMIDE, J. A. Produção de leite em regime de pasto. Revista da Sociedade Brasileira de Zootecnia, v. 22, p. 591 - 613, 1993.

GOMIDE, J.A.; GOMIDE, C.A.M. Utilização e manejo de pastagens. In: MATTOS W.R.S. (Ed.) A produção animal na visão dos brasileiros. Piracicaba: FEALQ, 2001. cap.54, p.808-825.

GOMIDE, J.A.; WENDLING, I.J.; BRAS, S.P. et al. Consumo e produção de leite de vacas mestiças em pastagem de Brachiaria decumbens manejadas sob duas ofertas diárias de forragem. Revista da Sociedade Brasileira de Zootecnia, v.30, n.4, p.1194-1199, 2001.

GRASSELLI, L.C.P.; GOMIDE, C.A.M.; PACIULLO, D.S.C. et al. Características morfogênicas e estruturais de um relvado de $B$. decumbens sob lotação contínua (compact disc). In: REUNIÃO ANUAL DA SOCIDEDADE BRASILEIRA DE ZOOTECNIA, 37., Viçosa, 2000. Anais. Viçosa: SBZ, 2000 
GUZMAN, G.A.B.; NASCIMENTO JÚNIOR, D.; REGAZZI, A.J. et al. Estudo do tamanho e forma ideal da unidade amostral na avaliação da disponibilidade de matéria seca em pastagens. I - Método da máxima curvatura do coeficiente de variação. Revista da Sociedade Brasileira de Zootecnia, v.21, n.3, p. 396-405, 1992.

HILLESHEIM, A . Fatores que afetam o consumo e perdas de capim elefante (Pennisetum purpureum Schum.) sob pastejo, Piracicaba, 1987, 94 p. Dissertação (Mestrado) - Escola Superior de Agricultura "Luiz de Queiroz", Universidade de São Paulo.

HODGSON, J. Grazing management: science into practice. New York: Longman Scientific \& Technical, 1990. 203 p.

HODGSON, J.; CLARK, D.A.; MITCHELL, R.J. Foraging behaviour in grazing animals and its impact on plant communities. In: FAHEY JR., J.C.; COLLINS, M.; MERTENS, D.R. et al. (Ed.) Forage quality, evaluation and utilization. Madison: ASA, CSSA, SSSA, 1994. p. 796-827.

HOLMES, C. W.; WILSON, G. F. Milk production from pasture. Palmerston North: Butterworths of New Zeland, 1984. 319p.

LACA, E.A.; LEMAIRE, G. Measuring sward structure. In: MANNETJE, L.; JONES, R.M. (Ed.). Field and laboratory methods for grassland and animal production research. Wallingford: CAB Internacional, 2000. p.103122. 
LEMAIRE, G. Ecophysiology of grasslands: Dynamic aspects of forage plant populations in grazed swards. In: INTERNATIONAL GRASSLAND CONGRESS, 19., São Pedro, SP, 2001. Proceedings. São Pedro: Brazilian Society of Animal Husbandry, 2001. p.29-38.

LEMAIRE, G.; AGNUSDEI, M. Leaf tissue turn-over and efficiency of herbage utilisation In: INTERNACIONAL SYMPOSIUM ON GRASSLAND ECOPHYSIOLOGY AND ECOLOGY, Curitiba, 1999. Anais. Curitiba: UFPR, 2001. p.165-186.

LEMAIRE, G.; CHAPMAN, D. Tissue flows in grazed plant communities. In: HOGDSON, J.; ILLIUS, A.W. (Ed.) The ecology and management of grazing systems. Wallingford: CAB International, 1996. cap.1, p.3-36.

LIMA, C.G. Analise de dados longitudinais provenientes de experimentos em blocos Casualizados. Piracicaba, 1996. 126p. Tese (Doutorado) - Escola Superior de Agricultura "Luiz de Queiroz", Universidade de São Paulo.

LOURENÇO L.F.; COELHO, R.D.; SORIA, L.G.T. et al. Coeficiente da cultura $\left(\mathrm{K}_{\mathrm{c}}\right)$ do capim Tanzânia (Panicum maximum Jacq.) irrigado por pivô central. In: REUNIÃO ANUAL DA SOCIEDADE BRASILEIRA DE ZOOTECNIA, 38., Piracicaba, 2001. Anais. Piracicaba: SBZ, 2001. p.316-317.

MARTHA JÚNIOR, G.B.; CORSI, M.; MAULE, R.F. et al. Métodos de determinação da área basal de uma pastagem de capim Elefante. Revista Sciencia Agricola, v.56, n.3, p.645-649, 1999. 
McINTYRE, G.A. Statistical aspects of vegetation sampling. In: MANNETJE, L. (Ed.) Measurement of grassland vegetation and animal production. Berkshire: CAB, International Bureau of Pastures and Field Crops, 1987. p.8-21.

MECELIS, N.R. Estudo da rebrota do capim Colonião (Panicum maximum Jacq.) submetido a diferentes tipos de manejo. Jaboticabal, 1979, 57p. Dissertação (Mestardo) - Faculdade de Ciências Agrárias e Veterinária, Universidade Estadual Paulista.

MERTENS, D.R. Regulation of forage intake. In: FAHEY JR., J.C.; COLLINS, M.; MERTENS, D.R. et al. (Ed.) Forage quality, evaluation and utilization. Madison: ASA, CSSA, SSSA, 1994. p. 450-493.

MINSON, D.J. Forage in ruminant nutrition. San Diego: Academic Press, 1990. $483 \mathrm{p}$.

NABINGER, C. Eficiência do uso de pastagens: disponibilidade e perdas de forragem. In: SIMPÓSIO SOBRE MANEJO DA PASTAGEM, 14., Piracicaba, 1997. Anais. Piracicaba: FEALQ, 1997. p.213-252.

NABINGER, C.; PONTES, L.S.; Morfogênese de plantas forrageiras e estrutura do pasto. In: MATTOS W.R.S. (Ed.) A produção animal na visão dos brasileiros. Piracicaba, 2001. Piracicaba: FEALQ; SBZ, 2001. cap. 52. p.755-771.

PEDREIRA, C.G.S.; MELLO, A.C.L.; OTANI, L. O processo de produção de forragem em pastagens. In: MATTOS W.R.S. (Ed.) A produção animal na visão dos brasileiros. Piracicaba, 2001. Piracicaba: FEALQ; SBZ, 2001. cap. 53 p.772-807. 
PENATI, M.A.; CORSI, M.; MARTHA JR, G.B.; SANTOS, P.M. Manejo de plantas forrageiras no pastejo rotacionado. In: SIMPÓSIO GOIANO SOBRE PRODUÇÃO DE BOVINOS DE CORTE, Goiânia, GO, 1999. Anais. Goiânia: CBNA, 1999. p.123-144.

PENATI, M.A.; SANTOS, P.M.; CASTRO, P.R.C. Avaliação da aplicação de reguladores vegetais sobre o desenvolvimento do capim Tanzânia (Panicum maximum Jacq.) (compact disc). In: REUNIÃO ANUAL DA SOCIDEDADE BRASILEIRA DE ZOOTECNIA, 37., Viçosa, 2000. Anais. Viçosa: SBZ, 2000.

PETERNELLI, M.; CANTO, M.W.; ALMEIDA JÚNIOR, J. et al. Características de pastagem em capim Tanzânia (Panicum maximum Jacq cv Tanzânia - 1) diferido e manejado em diferentes alturas de pastagem, no período de inverno (compact disc). In: REUNIÃO ANUAL DA SOCIDEDADE BRASILEIRA DE ZOOTECNIA, 37., Viçosa, 2000. Anais. Viçosa: SBZ, 2000, CD-ROM.

PONTES, L.S.; CARVALHO, P.C.F.; SILVEIRA, E.O. et al. Eficiência de utilização de azevém (Lolium multiflorum Lam.) manejado a diferentes alturas. In: REUNIÃO ANUAL DA SOCIEDADE BRASILEIRA DE ZOOTECNIA, 38., Piracicaba, 2001. Anais. Piracicaba: SBZ, 2001a. p.263-264.

PONTES, L.S.; CARVALHO, P.C.F.; SILVEIRA, E.O. et al. Variáveis morfogênicas de azevém (Lolium multiflorum Lam.) manejado a diferentes alturas. In: REUNIÃO ANUAL DA SOCIEDADE BRASILEIRA DE ZOOTECNIA, 38., Piracicaba, 2001. Anais. Piracicaba: SBZ, 2001b. p.266-268. 
POPPI, D.P.; HUGHES, T.P.; L'HUILLIER, P.J. Intake of pasture by grazing ruminants. In: NICOL, A.M. (Ed.) Livestock feeding on pasture. Ruakura: New Zealand Society of Animal Production, 1987, Cap. 4, p. 55-64.

REGO, F.C.A.; CECATO, U.; CANTO, M.W. et al. Qualidade do capim Tanzânia (Panicum maximum Jacq. cv. Tanzânia-1) manejado em diferentes alturas, sob pastejo. In: REUNIÃO ANUAL DA SOCIEDADE BRASILEIRA DE ZOOTECNIA, 38., Piracicaba, 2001. Anais. Piracicaba: SBZ, 2001a. p.117-118.

REGO, F.C.A.; CECATO, U.; CANTO, M.W. et al. Estudo de características morfológicas e índice de área foliar do capim Tanzânia (Panicum maximum Jacq. cv. Tanzânia-1) manejado em diferentes alturas, sob pastejo. In: REUNIÃO ANUAL DA SOCIEDADE BRASILEIRA DE ZOOTECNIA, 38., Piracicaba, 2001. Anais. Piracicaba: SBZ, 2001b. p.118-120.

RIBEIRO, H.M.N.; ALMEIDA, E.X. de; HARTHMANN, O.E.L. et al. Consumo de forragem por bovinos submetidos a diferentes ofertas de capim Elefante anão cv. "Mott". In: REUNIÃO ANUAL DA SOCIEDADE BRASILEIRA DE ZOOTECNIA, 34., Juiz de Fora, 1997. Anais. Juiz de Fora: SBZ, 1997. p.274-275.

SAS INSTITUTE. SAS: user's guide statistics. Version 6.10 edition. Cary, 1995. 956p.

SBRISSIA, A.F.; DA SILVA, S.C. O ecossistema de pastagens e a produção animal. In: MATTOS W.R.S. (Ed.) A produção animal na visão dos brasileiros. Piracicaba, 2001. Piracicaba: FEALQ; SBZ, 2001. cap.51, p.731-754. 
SILVA, D.S.; GOMIDE, J.A.; FONTES, C.A.A. et al. Pressão de pastejo em pastagem de capim Elefante Anão (Pennisetum purpureum, Schum. cv. Mott) - Efeito sobre a estrutura e disponibilidade de pasto. Revista da Sociedade Brasileira de Zootecnia, v.23, n. 2, p. 249-257, 1994.

SOLLENBERGER, L.E.; BURNS, J.C. Canopy characteristics, ingestive behaviour and herbage intake in cultivated tropical grasslands. In: INTERNATIONAL GRASSLAND CONGRESS, 19., São Pedro, SP, 2001. Proceedings. São Pedro: Brazilian Society of Animal Husbandry, 2001. p.321-328.

STOBBS, T. H. The effect of plant structure on the intake of tropical pastures. I. Variation in bite size of grazing cattle. Australian Journal of Agricultural Research, v. 24, p. 809-818, 1973.

STOBBS, T. H. The effect of plant structure on the intake of tropical pasture. III. Influence of fertilizer nitrogen on the size of bite harvested by jersey cows grazing Setaria anceps cv. Kazungula swards. Australian Journal of Agricultural Research, v. 26, p. 997-1007, 1975.

TEIXEIRA, E.I. Avaliação de características morfofisiológicas e nutricionais do capim Tobiatã (Panicum maximum cv. Tobiatã) sob sistema de pastejo rotacionado. Piracicaba, 1998. 87p. Dissertação (Mestrado) - Escola Superior de Agricultura “Luiz de Queiroz”, Universidade de São Paulo.

TOSI, P. Estabelecimento de parâmetros agronômicos para o manejo e eficiência de utilização de Panicum maximum (Jacq.) cv. Tanzânia sob pastejo rotacionado. Piracicaba, 1999. 103p. Dissertação (Mestrado) Escola Superior de Agricultura "Luiz de Queiroz", Universidade de São Paulo. 